\title{
Receptors, Mediators, and Mechanisms Involved in Bacterial Sepsis and Septic Shock
}

\author{
Edwin S. Van Amersfoort, $†$ Theo J. C. Van Berkel, and Johan Kuiper* \\ Division of Biopharmaceutics, Leiden/Amsterdam Center of Drug Research, \\ Leiden University, Leiden, The Netherlands
}

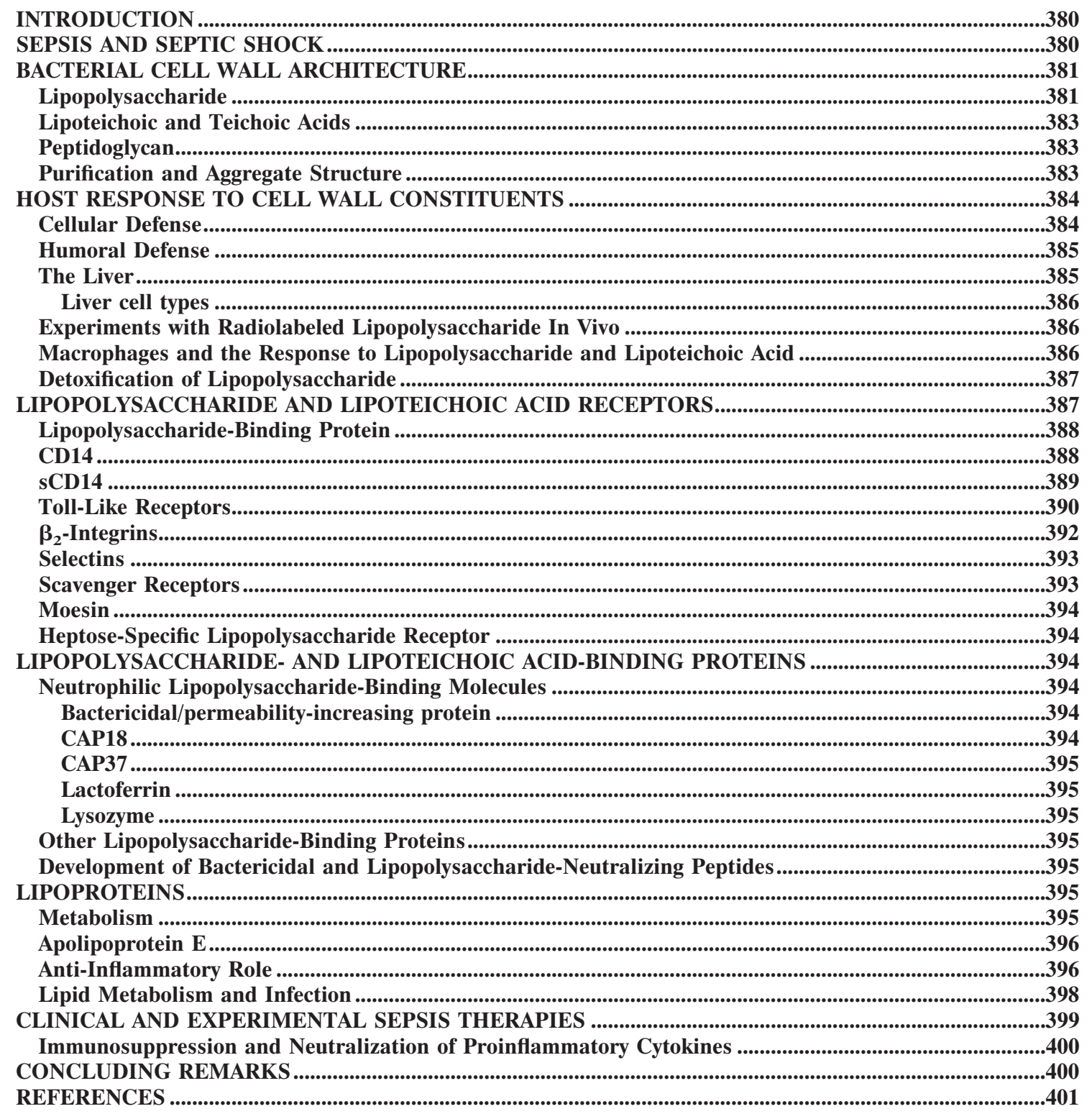

\footnotetext{
* Corresponding author. Mailing address: Division of Biopharmaceutics, Gorlaeus Laboratories, Leiden/Amsterdam Center for Drug Research, P.O. Box 9502, 2300 RA Leiden, The Netherlands. Phone: 31-71-5274378. Fax: 31-71-5276032. E-mail: j.kuiper@CHEM.leidenuniv .nl.

$\dagger$ Present address: Regulatory Affairs, Organon NV, 5340 BH Oss, The Netherlands.
} 


\section{INTRODUCTION}

Throughout the ages, mankind has suffered from diseases caused by microorganisms. These microorganisms often caused severe disease and significantly reduced life expectation. The era of modern microbiology started with the observations by Antonie van Leeuwenhoek at the end of the seventeenth century. Later, Klebs indicated the presence of bacteria in lesions, whereas Koch established that "each infectious disease stems from a specific microbe" and made a pure culture of Bacillus anthracis. During these years the first exotoxins, heat-sensitive substances secreted actively by many bacteria and causing illness, were isolated (453). In 1892, Pfeiffer's discovery of a heat-stabile toxin synthesized by Vibrio cholerae initiated lipopolysaccharide (LPS) research.

Under normal circumstances, many bacteria live in coexistence with humans. The skin, digestive tract, upper respiratory tract, external urogenital organs, and conjunctiva all contain commensal bacteria that do not cause disease. In particular, the intestinal tract contains billions of bacteria such as Escherichia coli that contribute to the function of the intestine. Similarly, bacteria such as Lactobacillus acidophilus are involved in maintaining an acidic climate in the vagina while bacteria such as Staphylococcus epidermidis on the skin aid in the defense against invading microorganisms through production of several bactericidal substances. The presence of bacteria on or in these organs is not a threat to the body because the nasal and oral cavities, respiratory and digestive tracts, and urogenital organs are connected to the "external environment" and are thus separated from the normally sterile "internal environment."

Pathogenic as well as commensal microorganisms evoke an immune response if they, or their constituents, pass the barrier between the external and internal environment. After recognition of the bacteria or their products, the body launches an attack, kills the bacteria, and repairs putative damage. This sequence of events is highly regulated, enabling the body to combat infection by a tailor-made attack that is fierce enough to eradicate the bacteria but not so fierce as to cause unnecessary damage to the body.

As some of the first living organisms on Earth, bacteria evolved and have been endowed with an enormous capacity to adapt to changes in environment. Bacteria are the result of millions of years of evolution and are-despite their simplicity compared to multicellular organisms-highly refined.

The scope of the review is to discuss the different components of the various bacteria that are involved in the process of sepsis and/or septic shock. The interactions of the various bacterial components with receptors and other proteins are discussed in detail. The consequences of binding of the bacterial components to these receptors and other proteins for the process of sepsis and septic shock is discussed in terms of cellular activation and production of pro- and anti-inflammatory proteins. Finally, some newer therapies for the treatment of sepsis are reviewed.

\section{SEPSIS AND SEPTIC SHOCK}

Until the beginning of the 20th century, reports describing infections other than those due to Salmonella enterica serovar
Typhi (typhoid fever) and Yersinia pestis (plague) were rare. Sepsis and septic shock, caused by gram-negative and grampositive bacteria, fungi, viruses, and parasites, have become increasingly important over the past decades (168). In the United States, the septicemia rates more than doubled between 1979 and 1987 causing up to 250,000 deaths annually $(403,413)$. In three distinct studies, the proportion of infections due to gram-negative bacteria varied between 30 and $80 \%$ and that of infections due to gram-positive bacteria varied between 6 and $24 \%$ of the total number of cases of sepsis, with the remainder being accounted for by other pathogenic organisms (168). However, the contribution of gram-positive bacteria to sepsis has increased, and in the early 1990s it accounted for more than $50 \%$ of all cases of septicemia $(27,161)$, with Staphylococcus aureus and S. epidermidis being responsible for more than half of the cases of sepsis due to gram-positive bacteria $(27,161)$. The increasing septicemia rates are probably caused by the increasing use of catheters and other invasive equipment, by chemotherapy, and by immunosuppression in patients with organ transplants or inflammatory diseases. Furthermore, improvements in medical care have resulted in longer life spans for the elderly and patients with metabolic, neoplastic, or immunodeficiency disorders. These groups remain at increased risk for infection $(42,44)$.

Due to differences in interpretation of the clinical condition "septic shock," reported mortality rates in patients with septic shock vary from 20 to $80 \%$ (42). The mortality is related to both the severity of sepsis and the underlying disease that is nearly always present $(42,43,413)$. In many cases of sepsis, the presence of microorganisms (bacteremia) or LPS in the blood (endotoxemia) cannot be established, which has prompted modification of the definitions of sepsis and septic shock (42, 43, 561). The definitions are as follows: bacteremia, positive blood cultures; sepsis, clinical evidence of infection, tachypnea ( $>20$ breaths/min), tachycardia ( $>90$ beats/min), hyperthermia, or hypothermia; sepsis syndrome, sepsis plus hypoxemia or elevated plasma lactate levels or oliguria; and septic shock, sepsis syndrome plus hypotension (despite adequate volume resuscitation).

The clinical phenomena preceding the development of sepsis and septic shock are highly complex. Paradoxically, as mentioned above, persons with a weakened immune system are most likely to develop sepsis, but the detrimental processes that may ultimately lead to the death of the patient are mostly caused by an exaggerated, systemic response to an infection. The widespread activation of cells responsive to bacteria or bacterial components results in the release of an array of inflammatory mediators, such as cytokines, chemokines, prostaglandins and lipid mediators, and reactive oxygen species. These compounds induce vasodilatation and upregulation of adhesion molecules, resulting in extravasation of neutrophils and monocytes; activation of leukocytes, lymphocytes, and endothelial cells; and myocardial suppression (218, 251, 413, 570). Besides stimulation of coagulation by cytokines, bacterial components may directly interact with the coagulation system. The resulting disseminated intravascular coagulation causes hypoperfusion and hypoxia. Together with the damage caused by the intra- and extravascular phagocytic cells, these conditions lead to organ failure $(338,551)$. This may initiate the often lethal stage of sepsis, in which multiple-organ failure, 


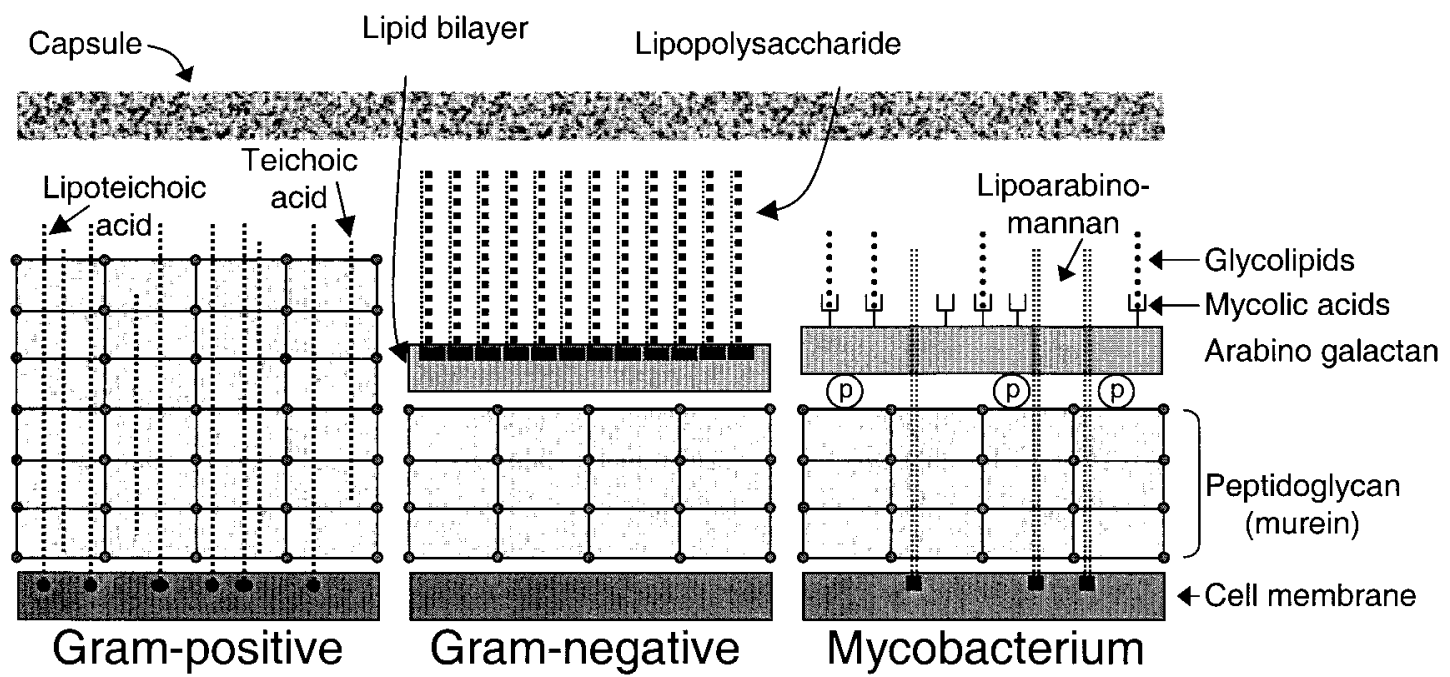

FIG. 1. Cell wall structure of bacteria. All types of bacteria contain a cell membrane surrounded by a PGN-containing layer. LTA and LAM are inserted into the cell membrane of gram-positive bacteria. LPS forms the outer layer of the outer membrane of gram-negative bacteria. The mycobacteria also contain a carbohydrate shell, but not all bacteria contain a capsule.

mostly involving the lungs (acute respiratory distress syndrome), liver, and kidneys, develops $(42,413,585)$. In addition, the hypoperfusion caused by disseminated intravascular coagulation may impair the gut mucosal barrier and result in translocation of bacteria to the mesenteric lymph nodes and, under conditions of ongoing stress, to several organs and the circulation. The released bacteria will "feed" the multiple-organ failure and significantly worsen the prognosis (608).

There are marked differences in the responses to grampositive and gram-negative bacteria. Whereas gram-negative bacteria all contain LPS as their major pathogenic determinant, gram-positive bacteria contain a number of immunogenic cell wall components besides the highly deleterious exotoxins $(403,495)$. The immunological response to gram-negative bacteria mainly involves leukocytes and the production of cytokines such as tumor necrosis factor alpha $(\mathrm{TNF}-\alpha)$, interleukin-1 (IL-1), and IL-6. The release of exotoxins, many of which are superantigens, by gram-positive bacteria activates $\mathrm{T}$ cells, resulting in a different cellular response and different cytokine profile, with relatively low levels of TNF- $\alpha$, IL-1, and IL-6 and increased levels of IL-8 (44, 403, 495).

\section{BACTERIAL CELL WALL ARCHITECTURE}

LPS and lipoteichoic acid (LTA) are the main building blocks of the outer leaflets of bacterial cell wall membranes and as such contribute to and are essential for stability and growth. Often they are not directly exposed to the external environment because many naturally occurring gram-positive and gram-negative bacteria are fitted with a thick polysaccharide capsule (455). In Fig. 1, schematic representations of the gram-positive and gram-negative cell walls are shown.

\section{Lipopolysaccharide}

LPS is a major constituent of the outer membrane of gramnegative bacteria and is the only lipid constituent of the outer leaflet; a single $E$. coli cell contains approximately $3.5 \times 10^{6}$
LPS molecules (454). Other componentsof the bacterial outer membrane are glycerolphospholipids in the inner leaflet and inner membrane and proteins (e.g., pore proteins such as OmpA in E. coli), some of which are firmly associated with the LPS molecules (328). LPS is an essential compound of the cell wall and is a prerequisite for bacterial viability. The LPS molecules is not toxic when it is incorporated into the bacterial outer membrane, but after release from the bacterial wall, its toxic moiety, lipid A, is exposed to immune cells, thus evoking an inflammatory response. LPS and other cell wall constituents are released from the bacterial cells when they multiply but also when bacteria die or lyse $(209,209,454)$. Various endogenous factors like complement and bactericidal proteins can cause disintegration of bacteria, resulting in the release of LPS (82). In addition, some antibiotics are known to cause the release of LPS from bacteria (71).

The LPS molecule consists of four different parts (Fig. 2) $(328,443,454)$. The first and most essential part is lipid A, the covalently linked lipid component of LPS. Six or more fatty acid residues are linked to two phosphorylated glucosamine sugars. Four of these fatty acids carry a hydroxyl group on the third carbon, whereas the other two are not hydroxylated. All bacterial species carry unique LPS, and some of the variations reside in the lipid A moiety: (i) acylation pattern, which is commonly asymmetric $(4+2)$, or a symmetric $(3+3)$ configuration (e.g., in Neisseria meningitidis); (ii) length of the fatty acid residues; typically three or four different fatty acids are present, with a length between 10 and $16 \mathrm{C}$ atoms (average, 14 $\mathrm{C}$ atoms); (iii) the presence of 4-amino-deoxy-L-arabinose and/or phosphoethanolamine linked to the phospho groups on the glucosamine sugars; and (iv) The number of fatty acids (most common bacteria contain six fatty acid residues). Experiments with synthetic lipid A have shown that this part of the LPS molecule represents the toxic moiety (274). A number of synthetic derivatives of lipid A (dephosphorylated or deacylated) have been tested in vivo and in vitro, and the potency of these molecules was 10 - to 1,000 -fold reduced with respect to 
A

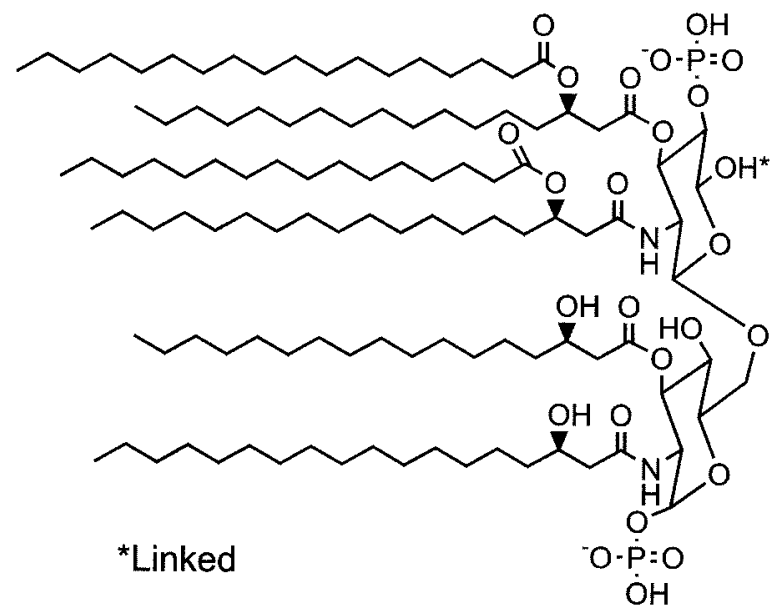

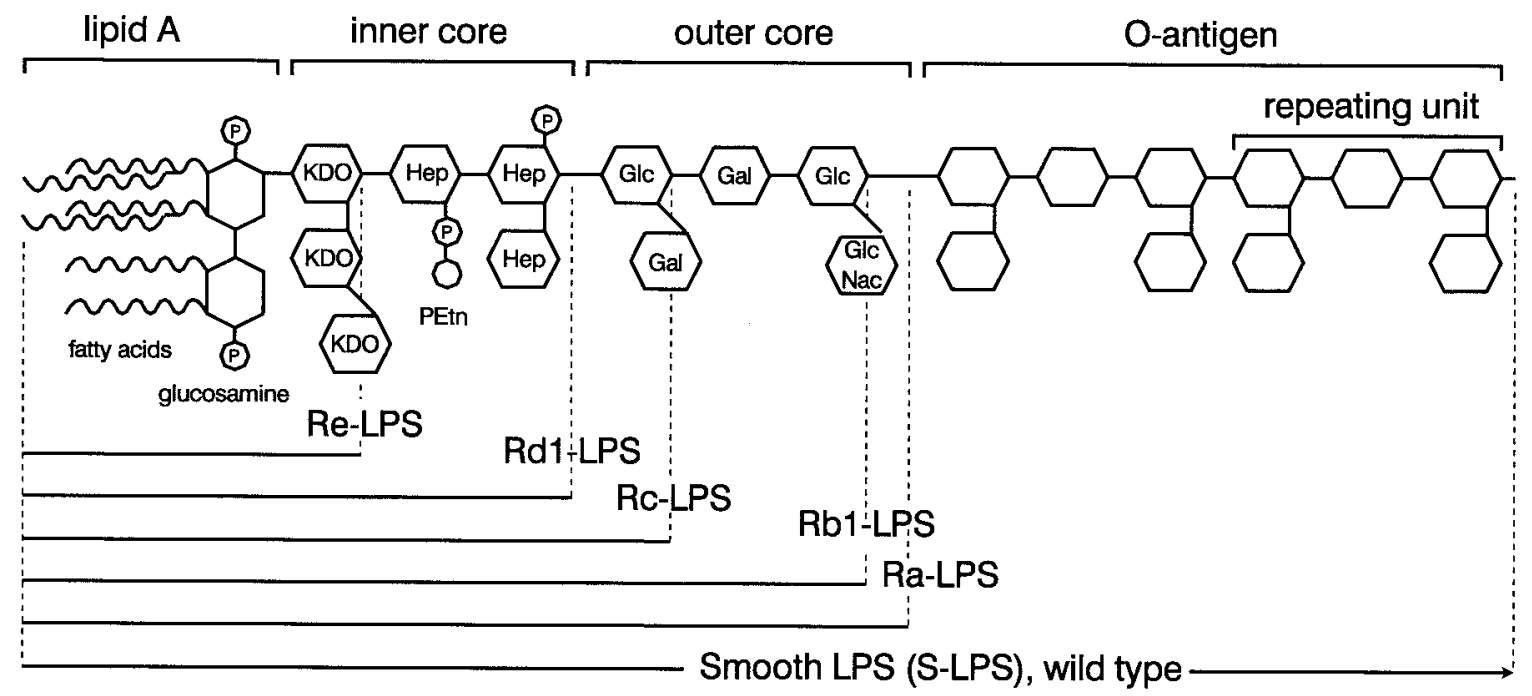

FIG. 2. Structure of lipid A (443) (A) and whole LPS (B). The composition and length of several LPS serotypes are indicated.

the original lipid A molecule $(99,325,378)$. In addition, the lipid a Precursor, lipid $\mathrm{IV}_{\mathrm{A}}$, dose dependently inhibits the effects of lipid A, as shown by reduced TNF- $\alpha$ and prostaglandin $\mathrm{E}_{2}\left(\mathrm{PGE}_{2}\right)$ production in vitro (169). Another lipid A precursor, lipid X, has limited lipid A antagonist activity (169). This illustrates that lipid A-induced cell activation requires a stricter structure than lipid A binding to the receptor per se.

The second part of the LPS molecule is the inner core, which consists of two or more 2-keto-3-deoxyoctonic acid (KDO) sugars linked to the lipid A glucosamine and two or three heptose (L-glycero-D-manno-heptose) sugars linked to the KDO. Both sugars are unique to bacteria. The smallest LPS molecule produced by gram-negative bacteria under natural conditions is Re-LPS (lipid A with one or two KDO sugars), but longer LPS molecules are more common. The Rd1- and Rd2-LPS serotypes contain a complete inner core and an inner core lacking two heptose sugars, respectively.
The outer core, the third part of the LPS molecule, consists of common sugars and is more variable than the inner core. It is normally three sugars long with one or more covalently bound sugars as side chains. LPS serotypes consisting of lipid $\mathrm{A}$ and the complete inner and outer core are denoted Ra-LPS, whereas the Rb- and Rc-LPS serotypes only contain a part of the outer core.

The fourth moiety of the LPS molecule is the O antigen. This part of the LPS molecule is attached to the terminal sugar of the outer core, extends from the bacterial surface, and is highly immunogenic. It is composed of units of common sugars, but there is a huge interspecies and interstrain variation in the composition and length. In a single LPS preparation, the length of the $\mathrm{O}$ antigen may vary from 0 to as many as 40 repeating units, but it generally consists of 20 to 40 repeating units. Each unit is composed of three sugars with a single sugar connected to the first and third sugar of the unit. LPS mole- 


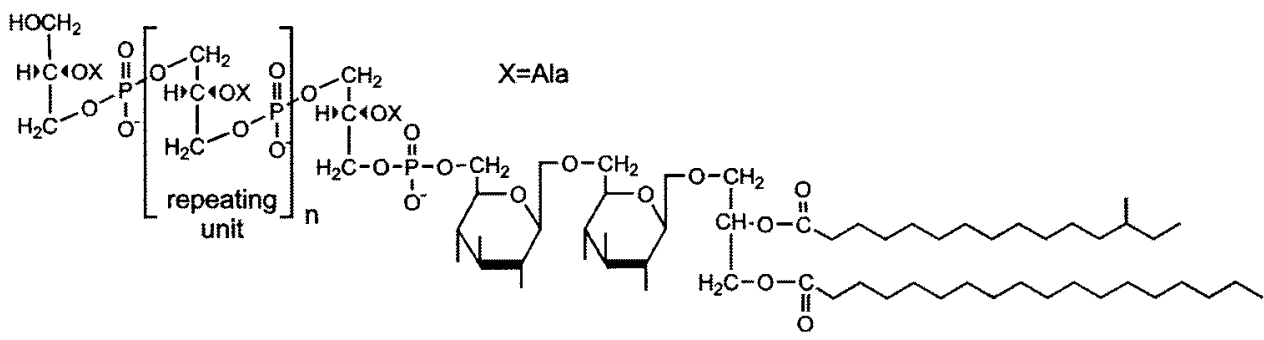

FIG. 3. Structure of LTA from S. aureus (131). Ala, alanine.

cules with $\mathrm{O}$ antigen are denoted S-LPS. Colonies from bacteria with O-antigen-containing LPS have a smooth (S) appearance on the plate, while bacteria that express an O-antigen-lacking LPS have a rough $(\mathrm{R})$ appearance.

\section{Lipoteichoic and Teichoic Acids}

LTA resembles LPS in certain respects and can therefore be considered the gram-positive counterpart of LPS (Fig. 3). It contains a diacylglycerol lipid moiety instead of a phospholipid-like structure as well as highly charged glycerophosphate repeating units, in contrast to the oligosaccharide-repeating units in LPS. Like LPS, LTA is essential for bacterial growth (131). It may be involved in the regulation of the $\mathrm{Ca}^{2+}$ and $\mathrm{Mg}^{2+}$ ion concentration in the cell wall and in the regulation of the activity of autolytic enzymes, and it may function as a carrier in cell wall teichoic acid synthesis $(132,460)$. The architecture of the gram-positive cell wall is markedly different from that of gram-negative bacteria, since it contains only a single cell membrane in which LTA molecules are inserted. The outside of the gram-positive cell wall is covered with a thick layer consisting of peptidoglycan (PGN) and teichoic acid (Fig. 1) (95).

The gram-positive bacterial cell membrane contains, in addition to LTA, other lipid constituents such as diglucosyldiacylglycerol, phosphatidylglycerol, diacylglycerol, and lysylphosphatidylglycerol $(131,132)$. In Staphylococcus aureus LTA, two acyl chains (the first generally unbranched and 16, 18, or $20 \mathrm{C}$ atoms in length and the second shorter and often branched) are linked to the 1 and 2 positions of the glucosylglycerol moiety (Fig. 3) (133). Comparison of the basic structure of LTAs from various species has revealed that all LTAs contain a single unbranched polyglycerophosphate chain phosphodiester-linked to the nonreducing hexapyranosyl residue of the diacylglycerol moiety (133). Marked interspecies differences were observed in the length of the acyl chains and in length and the carbohydrate composition of the glycerophosphate tail $(130,212)$.

A long tail of repeating 1,3-linked glycerophosphate units is connected to the glucoside moiety (131-133). The number of repeating units varies widely, depending on the species, strain, and growth conditions, but generally ranges between 4 and 30 for $S$. aureus $(130,465)$. D-Alanine may be incorporated at the 2 position of the glycerophosphate tail, but the extent of alanine substitution depends on factors, such as species, strain, growth conditions, and growth stage $(130,131,272)$. Various conditions may lead to the release of LTA from the cell wall, including the presence of certain antibiotics $(352,552)$.
In $S$. aureus, about $50 \%$ of the total mass of the cell wall consists of teichoic acid (165). Teichoic acid is composed of long chains of ribitol phosphate units that are partially replaced by ester-linked D-alanine. Teichoic acid is linked to the muramic acid of the cell wall PGNs via phosphodiester bonds (165).

\section{Peptidoglycan}

A major component of the cell wall of gram-positive bacteria is PGN, which is-although to a much lesser extent-also found in gram-negative bacteria. The glycan strands of the cell wall consist of repeating disaccharide $N$-acetylmuramic acid( $\beta 1-4)-N$-acetylglucosamine (MurNAc-GlcNAc) units (165, 384). The glycan strands may vary in length between 5 and 30 subunits, depending on the bacterial species. In most cases, the D-lactyl moiety of each MurNAc is amide linked to the short peptide component of PGN. The tetrapeptides, consisting of L-alanine, D-glutamine, L-lysine, and D-alanine, are crosslinked with other peptides that are attached to neighboring glycan strands, thereby generating a three-dimensional molecular network that surrounds the cell and provides the desired exoskeletal function $(165,384)$.

\section{Purification and Aggregate Structure}

Due to their lipophilic and hydrophilic moieties, LPS and LTA form aggregates in solution. Purified LTA forms simple, spherical micelles with a diameter of approximately $22 \mathrm{~nm}$ and consisting of around 150 LTA molecules (131). Due to its conical shape, LTA does not have the capacity to form membranes and therefore needs to be inserted in membranes formed by other lipids like those present in the bacterial cell membrane (131). In contrast, LPS aggregates may form several types of micellar structures due to a larger number of acyl residues in lipid A than in LTA. This results in an increased cross-sectional area of the lipophilic and hydrophilic moieties and a more cylindrical shape. For every LPS serotype, the temperature and ionic strength define its micellar structure that shifts from lamellar to cubic and/or hexagonal $(51,52)$. The capacity of different LPS serotypes to exert their endotoxic activity (e.g., cell activation) appears to be related to their micellar structure and fluidity $(52,329,472)$. The data from Schromm and coworkers provide an explanation for the fact that several LPS serotypes, such as that from Rhodobacter sphaeroides, are poor activators or, rather, are LPS antagonists: these LPS serotypes are in the lamellar state under physiolog- 
ical conditions which has been shown to correlate with poor agonistic activity $(329,472)$.

LPS and LTA can be purified using a number of isolation procedures employing phenol and-depending on the LPS serotype-chloroform and petroleum ether, yielding LPS and LTA preparations that may be contaminated with minor amounts of protein, phospholipids, divalent anions, and DNA $(66,152,367)$. In particular, the protein contaminants may affect the physiological behavior of LPS, including cellular binding, endotoxic potency, and lipoprotein binding (339, 340, $435,504,508)$. However, bacterial DNA is also able to activate macrophages (483). Similarly, the presence of a minor nonprotein constituent of LTA preparations with stimulatory capacity has been described $(283,284)$. Most of the contaminants in LPS and LTA preparations can be removed only by reextraction, reversed-phase chromatography, or electrodialysis (151, 340,488 ). Under physiological conditions, the LPS or LTA and their contaminants may behave as inseparable complexes impeding the analysis of the contribution of these contaminants to physiological processes (504).

Due to their numerous peptide cross-links, PGNs are isolated from rough cell wall preparations as insoluble fragments that can be broken down to soluble PGN by trypsin-mediated hydrolysis of the peptide bonds (334). Different levels of bioactivity have been described for isolated PGNs, which are up to 1,000 times less active than LPS. However, using the PGN hydrolase of Streptococcus pneumoniae, soluble PGN was obtained with bioactivity in the same range as that of LPS (334).

\section{HOST RESPONSE TO CELL WALL CONSTITUENTS}

As soon as a bacterium enters the body, it is confronted with two lines of defense: a humoral line and a cellular line. The humoral factors comprise complement, antibodies, and acutephase proteins. In the cellular line of defense, in particular the mononuclear cells (monocytes and macrophages) and the neutrophils are of great significance since these cells may recognize bacterial cell wall constituents directly or indirectly after complement and antibody bind to the bacterium and its constituents.

Under physiological conditions, the immune cells are continuously exposed to low levels of LPS derived from gastrointestinal bacteria that enter the body via the portal vein. This LPS is taken up by macrophages and may be essential to maintain a basal level of attentiveness of the immune system. At the end of the 19th century, LPS was mainly regarded as an "endotoxin," although Coley showed that heat-killed Serratia marcescens caused necrosis and hemorrhage of various tumors as well as causing fever (588). About 40 years later, Shear identified LPS as the agent responsible for the necrosis and hemorrhage. Buchner discovered that the immunological defense system could be nonspecifically activated against infection by injection with bacterial extracts $(565,588)$. It is now thought that continuous challenges with small amounts of bacterial constituents may be necessary to keep the immune system alert to infections. Indeed, low levels of LPS are present in healthy individuals without causing disease $(137,512,565)$.

\section{Cellular Defense}

As described in more detail below, LPS and other bacterial (surface) components are recognized by complement and antibodies, leading to opsonisation and lysis of the bacterium. Phagocytes (monocytes, macrophages, and polymorphonuclear leukocytes $[\mathrm{PMN}])$ are able to recognize opsonized bacterial components by complement receptors and Fc receptors (which bind immunoglobulin $\mathrm{G}[\mathrm{IgG}]$ antibodies) (140). Furthermore, they express receptors that recognize bacterial components. In the host response to bacteria, the mononuclear phagocytes (monocytes and macrophages) are of major importance (365). This was further illustrated in a mouse strain unresponsive to LPS: $\mathrm{C} 3 \mathrm{H} / \mathrm{HeJ}$ mice. When bone marrow from LPS-responsive $\mathrm{C} 3 \mathrm{H} / \mathrm{HeN}$ mice was injected into irradiated $\mathrm{C} 3 \mathrm{H} / \mathrm{HeJ}$ recipients, they became responsive to LPS (363). In addition, $\mathrm{C} 3 \mathrm{H} /$ HeJ mice could be rendered sensitive to LPS after injection of macrophages from $\mathrm{C} 3 \mathrm{H} / \mathrm{HeN}$ mice (147). Recognition of LPS or other bacterial components by these cells initiates a cascade of release of inflammatory mediators, vascular and physiological changes, and recruitment of immune cells. An LPS-activated macrophage becomes metabolically active and produces intracellular stores of oxygen free radicals and other microbicidal agents (lysozyme, cationic proteins, acid hydrolases, and lactoferrin) and secretes inflammatory mediators (214, 353, 456). One of the key mediators is TNF- $\alpha$ (39). After exposure to LPS, TNF- $\alpha$ is one of the first cytokines released by macrophages. TNF- $\alpha$ mRNA is constitutively transcribed in Kupffer cells, allowing rapid release of TNF- $\alpha$ after an inflammatory challenge (175). IL-1 and IL-6 are not constitutively expressed, but the mRNAs of these cytokines, as well as that of TNF- $\alpha$, are immediately transcribed after a challenge, and maximum mRNA levels have been found 40 min post-challenge in mouse liver macrophages $(175,331)$.

The release of TNF- $\alpha$, IL-1, IL-6, IL-8, IL-12, platelet-activating factor (PAF), chemokines, and eicosanoids has profound effects on the surrounding tissue $(179,252,330,438)$. In concert with the complement pathway-derived anaphylatoxins C3a and C5a, several of these inflammatory mediators attract PMN from the circulation and activate them. The extravasation of PMN is enabled by vasodilatation and upregulation of adhesion molecules on endothelial cells, PMN, and macrophages $(242,258,556)$. The PMN react to these stimuli by intravascular aggregation, adherence to the endothelium, diapedesis, and the production of inflammatory mediators like TNF- $\alpha$, leukotriene $B_{4}$, and PAF $(370,550)$. The (activated) PMN express CD14, CD11/CD18, and several complement and Fc receptors and are thus able to recognize and phagocytose LPS, bacterial fragments, and whole bacteria. As specialized phagocytes, PMN produce an impressive series of microbicidal agents, such as lysozyme, bactericidal/permeabilityincreasing protein (BPI), enzymes, and oxygen free radicals $(62,457)$. These agents are used mainly for lysosomal killing of microorganisms. However, adherence of the PMN to endothelial cells and the presence of high concentrations of stimuli may also result in the release of microbicidal agents; much of the endothelial damage observed in sepsis is caused by these agents (42). Endothelial cells respond to LPS (via soluble CD14) and to the circulating cytokines by the release of IL-1, IL-6, eicosanoids, the vasoactive agents endothelium derived 
relaxation factor and endothelin-1, chemokines, and colonystimulating factors (CSF) (332). The inflammatory mediators secreted by the different cell populations attract and activate $B$ and $\mathrm{T}$ lymphocytes. In turn, the latter release mediators such as IL-2, gamma interferon (IFN- $\gamma$ ), and granulocyte-macrophage (GM)-CSF (42). IL-2 and GM-CSF are involved in proliferation and activation of PMN and mononuclear cells, whereas IFN- $\gamma$ enhances the effects of LPS on mononuclear cells $(4,42$, $206,241,610)$. The actions of the activated immune cells combined with the effects of the inflammatory mediators cause symptoms such as fever, endothelial damage, capillary leakage, peripheral vascular dilatation, coagulation disorders, microthrombi, and myocardial depression. These phenomena may finally result in multiple organ dysfunction, shock, and death (42).

Compared to LPS, relatively little is known about the actions of LTA in vivo and in vitro. In contrast to gram-negative bacteria, in which LPS is the major biologically active moiety, in gram-positive bacteria LTA, PGNs, and exotoxins are highly relevant with respect to the immunological response (403). LTA and PGNs are able to induce the release of nitric oxide (NO), IL-1, IL-6, and TNF- $\alpha$ by monocytes and macrophages and to activate the oxidative burst in vitro $(40,100,259,263$, $518,574)$. Furthermore, the effects of LTA and PGNs may be synergistic (90). Like LPS, the bacterial species largely determines the potency of the biological actions of LTA $(40,259$, 261). In vivo both LTA and PGNs cause the release of NO, TNF- $\alpha$, and IFN- $\gamma$ and induce circulatory failure $(89,90,261)$, which indicates that gram-positive bacterial components such as LTA and PGNs induce similar effects to LPS both in vitro and in vivo.

In vivo challenges with viable and killed bacteria reveal marked differences between gram-positive and gram-negative bacteria in the kinetics of bacterium-induced TNF- $\alpha$ release, and similar differences were observed in vitro $(73,491)$. In contrast, LPS and LTA exhibit similar kinetics of TNF- $\alpha$ release in vivo (90). Despite the differences between bacteria and LPS, it has recently been shown that $S$. enterica serovar Typhimurium and its LPS induce similar changes in macrophagegene expression in vitro, confirming the early observations that LPS mimics whole gram-negative bacteria in many respects (462). The pathogenesis of gram-positive bacteria depends to a large extent on the production of powerful exotoxins. Grampositive bacterial sepsis differs from gram-negative bacterial sepsis in that the gram-positive bacteria often arise from skin, wounds, soft tissue structures, and catheter sites rather than enteric or genitourinary sources. Additionally, gram-positive organisms require a highly orchestrated host response, with intracellular killing by neutrophils and macrophages (403). This is often not the case for gram-negative pathogens, which may be readily killed in the extracellular space by antibody and complement (424, 495). Exotoxins may act as bacterial superantigens, which are potent T-cell-stimulatory protein molecules, produced by for instance $S$. aureus and $S$. pyogenes. These superantigens are able to induce toxic shock syndrome and can sometimes cause multiple organ failure $(25,44)$. The superantigenic activity of the bacterial exotoxins can be attributed to their ability to cross-link major histocompatibility complex class II molecules on antigen-presenting cells outside the peptide groove with $\mathrm{T}$-cell receptors to form a trimolecular complex (312). Each superantigen is known to interact with a specific V(beta) element of the T-cell receptor. This trimolecular interaction leads to uncontrolled release of a number of proinflammatory cytokines, especially IFN- $\gamma$ and TNF- $\alpha$, the key cytokines causing toxic shock syndrome (58). Besides the highly deleterious exotoxins, gram-positive bacteria contain a number of immunogenic cell wall components, such as LTA and PGNs $(403,495)$.

\section{Humoral Defense}

Bacteria activate both complement pathways: E. coli polysaccharide surface components (O antigen, capsule, and LPS) trigger the alternative pathway by binding to complement factor 3 (C3) $(246,436,521)$. Lipid A binds C1q and activates the classical pathway (609). The classical complement pathway is also activated in the presence of specific antibodies ( $\mathrm{IgG}$ and $\operatorname{IgM}$ ) against gram-negative bacterial constituents. In all three cases, $\mathrm{C} 3 \mathrm{~b}$ is deposited on the molecule or cell surface, which promotes phagocytosis by macrophages and neutrophils and leads to insertion of C5-C9 (membrane attack complex) into the cell surface, in many cases leading to lysis of the bacterium (83, 140). However, long O-antigen chains in gram-negative bacteria or the thick PGN layer of gram-positive bacteria may protect the bacteria from complement-mediated lysis (180). Similar to LPS. LTA activates the classical pathway by interacting with $\mathrm{C} 1$ and $\mathrm{C} 1 \mathrm{q}$ (324). In addition, erythrocyte boundLTA activates the alternative complement pathway resulting in lysis of the erythrocytes $(229,578)$.

With the cleavage of $\mathrm{C} 3$ and $\mathrm{C} 5$, the chemoattractive and vasoactive agents $\mathrm{C} 3 \mathrm{a}$ and $\mathrm{C} 5 \mathrm{a}$ are released. They cause increased vascular permeability, upregulate adhesion molecule expression on endothelial cells and neutrophils, and attract and activate these phagocytes. Furthermore, they activate basophilic granulocytes and mast cells: these cells release a variety of vasoactive compounds (such as histamine), facilitating the invasion of phagocytes $(116,223,280,370,434,457,521$, $550)$.

During infection, liver parenchymal cells are stimulated by TNF- $\alpha$, IL-1, and IL- 6 to produce acute-phase proteins. These proteins comprise $\mathrm{C}$-reactive protein, serum amyloid A, lipopolysaccharide-binding protein (LBP), serum amyloid $\mathrm{P}$, hemopexin, haptoglobin, complement C3 and C9, $\alpha_{1}$-acid glycoprotein, $\alpha_{2}$-macroglobulin, and some proteinase inhibitors $(129,476,498)$. The expression is differentially upregulated from severalfold (C3 and C9) to even 1,000-fold (C-reactive protein) (129). Some of the acute-phase proteins, like LBP modulate the immune response reactions by activation of phagocytes and antigen-presenting cells, but basically the acute-phase response is considered to alleviate the damage caused during infection $(129,280,444)$. Albumin is a so-called negative acute-phase protein since its production is down regulated during inflammation (129).

\section{The Liver}

The liver is the largest solid organ in the body, constituting 2 to $5 \%$ of the body weight in adults. Via the portal vein, the liver is provided with nutrients from the gastrointestinal tract. A major function of the liver is the uptake of these nutrients 
and their subsequent storage, metabolic conversion, and distribution to blood and bile. Of interest for this review, the liver is considered to be of major importance in the body's defense mechanism against bacteria and foreign macromolecules derived from bacteria and microorganisms $(92,270)$.

Liver cell types. The liver consists of five kinds of cells: liver parenchymal cells (hepatocytes), endothelial cells, fat-storing cells, pit cells, and Kupffer cells. The liver parenchymal cells represent $60 \%$ of the liver cells (423). Parenchymal liver cells are metabolically highly active and contain huge numbers of lysosomes, peroxisomes, Golgi complexes, and mitochondria (92). Important and specific metabolic pathways are the urea cycle, regulation of lipid metabolism, production of bile acid in relation to bile secretion, and hormonally regulated glycogenolysis and gluconeogenesis (423). Furthermore, liver parenchymal cells are major producers of plasma proteins (e.g., albumin) and, as mentioned above, acute-phase proteins (129). Sinusoidal endothelial cells account for approximately $19 \%$ of all liver cells. In contrast to vascular endothelial cells, these cells have no basement membrane and possess slender processes containing fenestrae, allowing direct contact between the plasma and the cells behind the endothelial barrier. Liver endothelial cells express several receptors that allow the endocytosis of (foreign) ligands, and during a bacterial infection, they produce several cytokines and eicosanoids $(82,278,452)$. Fat-storing cells are characterized by the presence of vitamin A-rich fat droplets in the cytoplasm. Some specific functions are uptake and storage of retinoids, as well as synthesis and secretion of extracellular matrix proteins (162). Pit cells are located in the sinusoids and exert natural killer (NK) activity (92). Kupffer cells are the liver macrophages; they are stellate and are situated in the sinusoids, where they are attached to endothelial cells (and parenchymal cells) by their pseudopodia. They constitute 80 to $90 \%$ of the fixed tissue macrophages (reticuloendothelial system) and account for approximately $15 \%$ of the liver cells. Kupffer cells remove all kinds of old, unnecessary, and damaged material from the circulation (immune complexes, erythrocytes, tumor cells, cellular debris, and apoptotic cells) $(485,530,571)$. In addition, they remove foreign materials from the blood with high efficacy $(92,278)$. In relation to the defense against bacteria and bacterial components, Kupffer cells are highly relevant (270, 530), playing a major role in both clearance and detoxification of LPS from the circulation (especially the portal vein) and the production of inflammatory mediators in response to LPS $(85,139,482$, 530, 571).

\section{Experiments with Radiolabeled Lipopolysaccharide In Vivo}

Klein et al. injected radiolabeled, live $E$. coli into the femoral vein of rats (270). At $5 \mathrm{~min}$ after injection, $80 \%$ of the bacteria had already been taken up by liver cells and the rest of the bacteria could be found in the lungs, spleen, and blood. Uptake was followed by degradation, which was almost complete after $24 \mathrm{~h}$ (270). However, the clearance of bacteria is species and strain specific, with generally higher residual levels for virulent strains than for avirulent strains (41). Mathison and Ulevitch injected rabbits intravenously (i.v.) with $250 \mu \mathrm{g}$ of either E. coli O111:B4 S-LPS or S. enterica serovar Minnesota Re595 ReLPS and observed a rapid serum decay $\left(t_{1 / 2}<30 \mathrm{~min}\right)$ and high clearance capacity of the liver (346). In an electron microscopy study by Van Bossuyt et al., at 5 min after the injection of radioactive $S$. enterica serovar Abortus-equi S-LPS into the portal vein, maximal association with Kupffer cells was observed (542). The association gradually decreased over 3 days, but increasing association with liver parenchymal cells was detected several hours after injection of the LPS and was paralleled by excretion of radioactivity into the bile. Mathison et al. obtained similar results (346). Freudenberg et al. observed that injected $S$. enterica serovar abortus-equi S-LPS bound to Kupffer cells and granulocytes $(145,149)$. Also in these experiments, LPS was redistributed from Kupffer cells to liver parenchymal cells. Although in general the decay of LPS in serum was rapid, with $t_{1 / 2}$ varying between $15 \mathrm{~min}$ and $3 \mathrm{~h}$ depending on the route of administration, dose, and animal used, bioactive LPS could be recovered from plasma for a long time (346, 432, 466). Using radioiodinated Re595-LPS, we found rapid decay in serum $\left(t_{1 / 2}<5 \mathrm{~min}\right)$ and a high liver uptake predominantly due to uptake by the liver Kupffer and endothelial cells $(75 \%)$, showing that the liver binding and decay in serum may vary with the LPS serotype and preparation used $(146,557)$.

\section{Macrophages and the Response to Lipopolysaccharide and Lipoteichoic Acid}

Macrophages play a pivotal role in the cellular response to LPS. The reticuloendothelial system consists of specialized tissue macrophages responsible for the primary response to microorganisms in most tissues. As described above, an immune reaction is aimed at eradicating the invading microorganism (lysis, phagocytosis) and preventing the spread of microorganisms and their toxic components or products (coagulation) to the rest of the body. It has been shown that macrophages are able to remove endotoxin and bacteria from the lymph and blood circulation and respond to the binding of LPS by the production of inflammatory mediators. The cells of the reticuloendothelial system have acquired tissue specific characteristics, which result in differences in their response to LPS. On challenge with LPS, LTA, or other bacterial components, macrophages release a series of inflammatory mediators such as TNF- $\alpha$, IL-1, IL-6, eicosanoids, PAF, NO, and reactive oxygen. Not only free LPS, LTA, and PGN but also live and killed bacteria can elicit the release of TNF- $\alpha(21,73,178,262$, 400, 491). The lipid mediators-eicosanoids and PAF-released by the macrophages and liver sinusoidal endothelial cells have important functions as well (197, 230, 254, 279). Besides the vasoactive functions of these agents $(368,369)$, $\mathrm{PGE}_{1}$ and $\mathrm{PGE}_{2}$ inhibit the transcription of TNF- $\alpha$ mRNA in macrophages, resulting in a long-term inhibition of TNF- $\alpha$ release $(175,317,389,458)$. The last group of products released in response to LPS are the reactive oxygen species. Activation of macrophages and infiltrating PMN by bacterial components and by TNF- $\alpha$ and other inflammatory mediators induces the intracellular production of $\mathrm{O}_{2}{ }^{-}, \mathrm{H}_{2} \mathrm{O}_{2}$, and other potent microbicidal products $(32,361)$. Although these compounds are responsible for killing phagocytosed microorganisms, they are released at high concentrations of activators and cause extensive tissue damage. Nitric oxide (NO) is a microbicidal product which is produced by macrophages, endothelial 
cells, and hepatocytes. Once secreted, it is rapidly converted to nitrate and nitrite and has a wide range of physiological effects (74, 298, 406, 493). Besides its (beneficial) microbicidal and tumoricidal effects, NO causes vasodilation, endothelial damage, damage to hepatocytes, inhibition of acute-phase protein production, and increased leukocyte adhesion in liver and lungs $(85,213,237,575)$.

Gadolinium chloride $\left(\mathrm{GdCl}_{3}\right)$ causes a transient depletion of the large, ED2-positive Kupffer cell fraction in rats $(81,192)$. Administration of $\mathrm{GdCl}_{3}$ reduces death and hepatic damage in rats treated with a lethal dose of LPS but does not prevent TNF- $\alpha$ production (231). Bautista et al. described a similar technique with liposome-encapsulated dichloromethylene biphosphonate $\left(\mathrm{Cl}_{2} \mathrm{MBP}\right)$; this reagent eliminated $90 \%$ of the largest Kupffer cell fraction and $50 \%$ of the smaller Kupffer cells (33). In addition, macrophages in the spleen are depleted after injection of these liposomes whereas circulating monocytes are spared (558). After i.v. injection of LPS into $\mathrm{Cl}_{2} \mathrm{MBP}$ liposome treated rats, serum TNF- $\alpha$ levels were significantly reduced (33). Similar decreases in TNF- $\alpha$, IL-1, and IL-6 production in liver slices from $\mathrm{Cl}_{2} \mathrm{MBP}$-liposome treated mice were observed (331).

An in vitro study with splenic macrophages and Kupffer cells has shown that splenic macrophages produce significantly more LPS-induced TNF- $\alpha$ than do Kupffer cells but that the latter phagocytose more latex beads in vitro and in vivo (486). In addition, Lichtman et al. showed that there are major differences in the activation pathway between peritoneal macrophages and Kupffer cells (316). Whereas the response of peritoneal macrophages to LPS was dependent on CD14 (see the section on LPS and LTA receptors, below), a mainly CD14independent activation pathway was utilized in Kupffer cells. The route of LPS entry into the body may also alter the immune response. Asari et al. have shown that the peak TNF levels and the kinetics of TNF release after intraperitoneal (i.p.) versus i.v. injection differ, confirming that the macrophages from relevant organs respond differently (13).

\section{Detoxification of Lipopolysaccharide}

There are several lines of evidence that LPS is processed after uptake by macrophages and PMN. Several investigators observed the displacement of LPS from Kupffer cells to hepatocytes after incubation times varying from several hours to days, indicating preferential binding of native LPS to Kupffer cells and preferential binding of Kupffer cell-released LPS to liver parenchymal cells $(139,148,543)$. Indeed, the observation that LPS, both modified and unmodified, binds to liver parenchymal cells may indicate that these cells are involved in the clearance of LPS from the circulation $(94,412)$. This is confirmed by the observations that LPS or LPS metabolites are excreted in bile and feces $(138,542)$. One of the intracellular degradation pathways may be the removal of fatty acids by acyloxyacyl hydrolase. This enzyme is present in the lysosomes of PMN and macrophages (253, 327, 373). Deacylated LPS probably has decreased biological activity (148, 188, 426, 450, 543 ) and actually antagonises the actions of native LPS (268, 316). A second method of processing may be digestion of the $\mathrm{O}$ antigen. LPS released by Kupffer cells showed a decreased sugar/lipid ratio compared to native LPS $(138,139)$. Hampton
TABLE 1. LPS and LTA receptors and some of their ligands

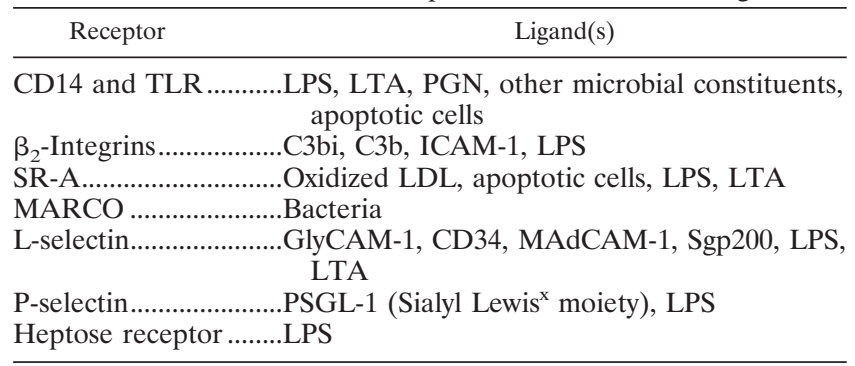

and Raetz described the dephosphorylation of LPS after binding to the scavenger receptor (186). Like deacylated LPS, dephosphorylated LPS appears to have a decreased biological activity (99). Poelstra et al. proposed that alkaline phosphatase is involved in detoxification of LPS (425). Treatment of LPS with alkaline phosphatase results in dephosphorylation in vitro, whereas blocking of alkaline phosphatase in vivo causes an enhanced sensitivity to $E$. coli in mice (425). Treon et al. isolated LPS that was released by Kupffer cells (531a). The Kupffer cell-released LPS exhibited a higher binding to liver parenchymal cells and a markedly reduced induction of TNF- $\alpha$ production by peritoneal macrophages. Furthermore, binding to the liver hepatocytes could not be inhibited by excess amounts of LPS, indicating that the LPS structure had been changed significantly (139). However, the nature of the changes and the receptors responsible for the uptake of the modified LPS were not identified.

\section{LIPOPOLYSACCHARIDE AND LIPOTEICHOIC ACID RECEPTORS}

Over the past 20 years, one of the major aims in LPS research has been the elucidation of the sequence of events between the binding of LPS to a cell and the response of the cell. One of the first LPS receptors to be characterized was the CD11b/CD18 or CR3 receptor (593). Binding of LPS-coated erythrocytes to PMN is mediated through this receptor. However, it turned out that the cells were not sufficiently activated through the CD11b/CD18 receptor, and the quest for identification of the cell-activating LPS receptor was continued. In 1990, CD14 (previously known only as a monocyte-specific antigen) was identified as the receptor involved in cellular activation (596). However, because CD14 lacks a transmembrane signaling domain, the involvement of an accessory receptor was proposed. Quite recently, the Toll-like receptors (TLR) were identified as the putative signaling receptor for LPS, LTA, and a variety of other microbial constituents (428). Although the precise nature of the CD14-TLR interactions has not been clarified, the events occurring after binding to the TLR are now being unraveled. In this section the various receptors involved in the uptake of, and in some cases activation by, LPS and LTA are described in further detail. The serum proteins LBP and soluble CD14 function as accessory receptors and are therefore also described in this section. Other LPS- or LTA-binding serum constituents are described in the next section. LPS and LTA receptors are listed in Table 1 , along with some of their ligands. 


\section{Lipopolysaccharide-Binding Protein}

LBP was first isolated from rabbit acute-phase serum by Tobias et al. (526). They observed differences in the binding of LPS to high-density lipoprotein HDL in normal and acutephase serum and discovered that LPS in acute-phase serum was mainly complexed with a protein. The LBP was recovered from serum as a $58-$ and $60.5-\mathrm{kDa}$ protein, the difference in molecular mass reflecting different degrees of glycosylation $(444,526)$.

LBP is an acute-phase protein $(473,476)$ and is induced by IL-6 and IL-1 (176, 444, 572). Besides the liver, the lungs, kidneys, and heart are also involved in the production of LBP (506). The constitutive levels of LBP in serum are low (1 to 15 $\mu \mathrm{g} / \mathrm{ml})$ but increase greatly during infection $(155,289,474,476$, 528). In humans during the acute phase of trauma or sepsis, LBP levels are at a maximum on days 2 to 3 (476). Most of the LBP in serum is associated with lipoproteins, and LBP in serum is mainly associated with low-density lipoprotein (IDL), very-low-density lipoprotein (VLDL), or HDL $(414,569,600)$.

LBP binds to smooth and rough LPS, lipid A, and lipid $\mathrm{IV}_{\mathrm{A}}$. The affinity of LBP for lipid A is high, with the $K_{d}$ varying from 1 to $58 \mathrm{nM}(158,527)$. The binding site for lipid A is situated in the N-terminal part between amino acids (aa) 91 and 108, with positively charged arginine and lysine residues within this region fulfilling an essential role $(290,519)$. The C-terminal part of the LBP molecule, however, mediates the transfer of LPS to CD14 $(187,522)$. The binding of LBP to killed bacteria is markedly higher than the binding to living bacteria (307).

LBP catalyses the transfer of LPS to CD14, thus enhancing the LPS-induced activation of monocytes, macrophages, and PMN by 100 - to 1,000 -fold (475). The CD14-mediated activation of peritoneal macrophages by heat-killed Staphylococcus aureus bacteria, LTA, cell wall PGN, or mycobacterial lipoproteins is not enhanced by $\operatorname{LBP}(345,357,478,524)$. In the presence of LBP, LPS induced an enhanced intracellular killing and secretion of TNF- $\alpha$ and NO by murine macrophages (68), increased adherence of human PMN to endothelial cells (590), LBP and CD14 release by HepG2 human hepatoma cells (383), and release of tissue factor by THP-1 cells in vitro (500), whereas the addition of anti-LBP or anti-CD14 antibodies abrogated the effect of $\operatorname{LBP}(154,500,590)$. Application of anti-LBP antibodies together with LPS protected D-galactosamine-sensitized mice from death $(155,156,307 \mathrm{a})$.

Besides its proinflammatory role, LBP may also have antiinflammatory actions, such as the LBP-mediated catalysis of LPS and LTA transfer to HDL and other lipoproteins (see the section on lipoproteins below). (177, 526, 600, 602). Recently, LBP was shown to be involved in the neutralization of LTA by HDL, extending the anti-inflammatory role of LBP to grampositive organisms (177). Interestingly, as mentioned above, LBP is not essential for binding of gram-positive cell wall components to CD14 while promoting the neutralization of LTA by lipoproteins, suggesting a solely anti-inflammatory function in the response to gram-positive organisms. The injection of LBP into D-galactosamine-sensitised mice decreased LPS-induced TNF and IL-6 release and significantly reduced mortality, and LBP was also found to be protective during an infection with live E. coli (289). Interestingly, Jack et al. observed that LBP knockout mice were less susceptible to a challenge with LPS but more susceptible to live $S$. enterica serovar Typhimurium (240), which is in line with the putative protective effect of LBP during bacterial infection. Wurfel et al. observed the absence of a response to LPS in whole blood from LBP knockout mice (601).

LBP binds certain phospholipids, which relates to its structural homology to other lipid-binding proteins like phospholipid transfer protein (PLTP), which is able to transfer LPS to HDL (182, 414, 612). By analysis of sequence homologies, it was found that LBP belongs to a family of lipid-binding proteins also containing BPI, PLTP, and cholesteryl ester transfer protein $(3,224,266,287)$.

\section{CD14}

LPS binding to and activation of mononuclear cells from CD18-deficient patients indicated the presence of additional receptors on macrophages and PMN $(592,597)$. The addition of anti-CD14 antibodies prevented binding of the LPS-coated erythrocytes to macrophages and decreased LPS-induced TNF- $\alpha$ release (596). Transfection of CD14-negative $\mathrm{CHO}$ and 70Z/3 cells with CD14 conferred responsiveness to LPS and positively identified CD14 as an LPS receptor $(170,302)$. Kirkland et al. determined the binding affinity of the LPS-LBP complex to CD14-transfected CHO cells and THP-1 cells and found $K_{d}$ values of $2.7 \times 10^{-8}$ to $4.8 \times 10^{-8} \mathrm{M}(265)$. The mechanism of LPS binding to CD14 is shown in Fig. 4.

Mice transgenic for human CD14 are three times more sensitive to LPS than are wild-type mice (128). In contrast, CD14deficient mice are highly resistant to a challenge with LPS (200). However, the CD14-deficient mice were less sensitive to a challenge with live gram-negative bacteria, due to the accelerated clearance of bacteria by PMN $(200,201)$. The clearance of live $S$. aureus and the TNF- $\alpha$ levels were even higher in CD14-deficient than in wild-type mice after a challenge with live $S$. aureus, indicating that CD14 is not of great importance in the in vivo defense against these gram-positive bacteria (202). Anti-CD14 antibodies applied to LPS-treated rabbits and cynomolgus monkeys decreased hypotension, neutropenia, TNF- $\alpha$ release, and organ damage, indicating that blocking of CD14 in severe endotoxemia could protect against the detrimental effects $(308,468)$.

Because CD14 is a glycosylphosphatidylinositol-linked receptor that lacks a transmembrane domain, it probably needs an accessory molecule for signal transduction (499). This hypothesis was confirmed using different anti-CD14 antibodies that either blocked LPS binding to CD14, or did not block LPS binding while preventing LPS-induced cell activation (163, 303). The accessory receptor has been identified as being a member of the TLR family.

Binding of LPS to a cell does not result in an immediate response. A time lapse of 15 to $30 \mathrm{~min}$ between LPS binding and LPS-induced responses such as cytokine release and adhesion was observed, which suggests that a time-consuming process such as internalization is necessary to enable signaling (93, 315). Indeed, several, but not all, studies have revealed that blocking internalization or endosome fusion also blocks LPS-induced signaling $(93,315,427,431)$. Although the precise mechanisms are not completely understood, it has been shown that monomeric LPS is transported into the cell to the 


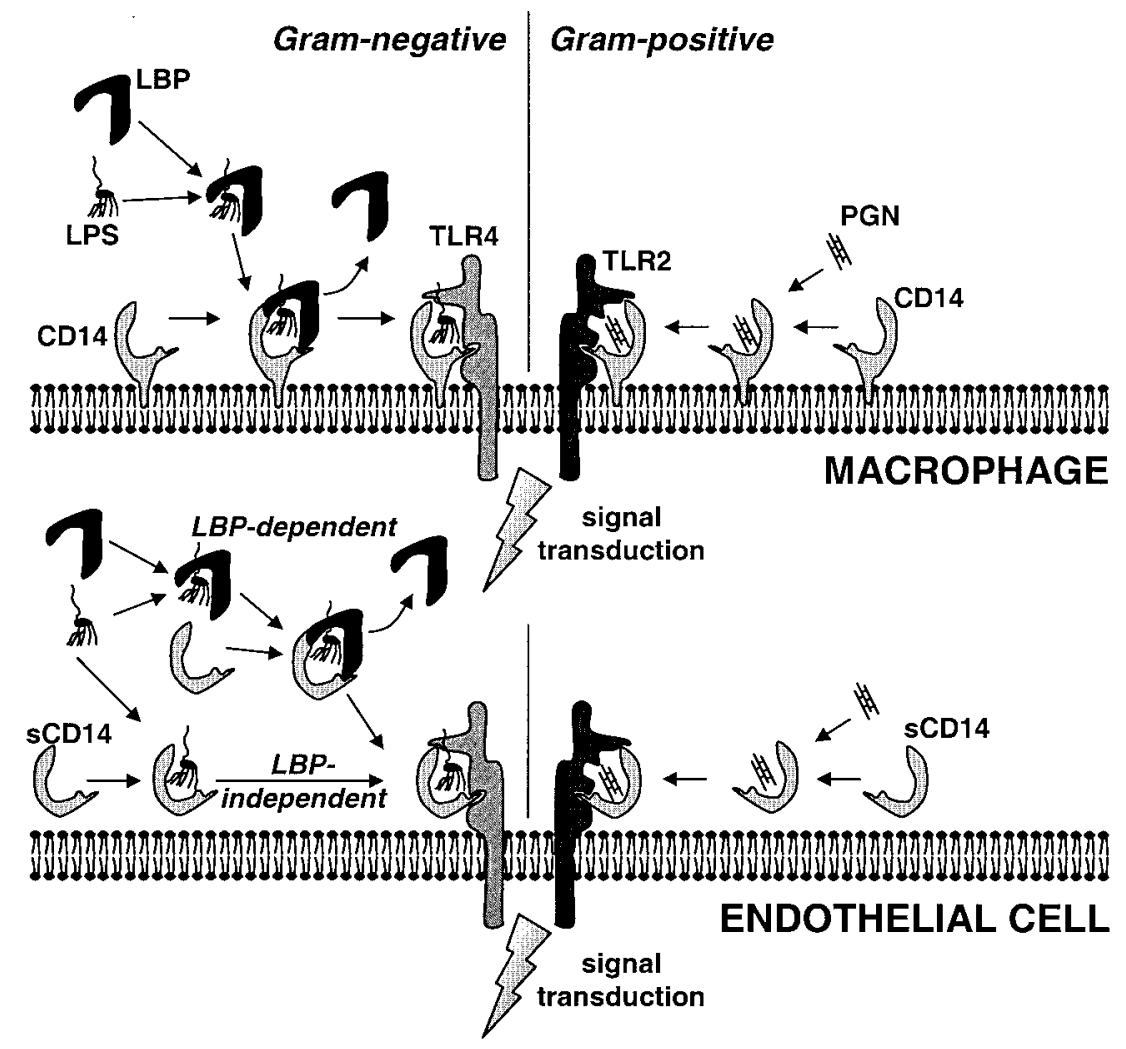

FIG. 4. Binding of bacterial ligands to CD14 and sCD14. The involvement of LBP, (s)CD14, and TLR2 and TLR4 in the activation of CD14-expressing cells (e.g., macrophages) and of cells that do not express CD14 (e.g., endothelial cells) is shown. LPS (left) and PGN (right) represent TLR4- and TLR2-specific ligands, respectively.

Golgi complex, thus activating the cell. In contrast, particulate (bacterium) or aggregated (micelles) LPS is transported through a CD14-dependent pathway to the lysosomes without activating the cell (461).

Although LPS was the first CD14 ligand discovered, many other microbial ligands for CD14 were later identified. These are also ligands for the TLRs, and these are discussed below. Molecular cloning of the CD14 gene revealed a 1.4-kb transcript encoding a 356-aa protein (126). CD14 is glycosylphosphatidylinositol linked and has a high leucine content $(17.7 \%$ human CD14, 15.5\% murine CD14) (484). A repeating leucine-rich, 24-residue motif (LxxLxLx) can be recognized $(127,484)$. The LPS-binding site and the sites involved in the interaction of CD14 with the putative accessory receptors have been identified in the N-terminal part of CD14 (250, 613). Two putative LPS-binding sites were mentioned: aa 39 to 44 (501) and aa 57 to $64(248,355)$. Stelter et al. also measured the LPSor E. coli-induced activation and found that the substitution mutant with substitution at aa 39 to 44 was not capable of inducing activation (501). Two other regions essential for sCD14-mediated signaling of endothelial and smooth muscle cells were also identified: aa 9 to 13 and aa 91 to $101(249,502)$.

CD14 is expressed by cells of the myeloid lineage (monocytes, macrophages, and PMN), B cells, liver parenchymal cells, gingival fibroblasts, and microglial cells (9, 322, 383, 421, 507, 616). Differential expression of CD14 is observed: peritoneal and pleural macrophages have a high level of constitutive CD14 expression, whereas (murine) Kupffer cells, alveolar macrophages, monocytes, and PMN have a low level of constitutive CD14 expression (9, 341, 350, 617). CD14 is absent from early progenitor (myeloid) cells, but CD14 expression increases with maturation (164). In vivo challenge of mice with LPS results in up regulation of CD14 on Kupffer cells but also in the heart, lungs, spleen, and kidneys (119, 350). Human PMN express low levels of CD14, but the expression can be upregulated by TNF- $\alpha$, granulocyte (G) CSF, GM-CSF and fMLP (formyl-Met-Leu-Phe) within $20 \mathrm{~min}$, indicating that the CD14 originates from intracellular stores $(205,595)$.

\section{sCD14}

In 1986, the excretion of the MY-4 antigen (CD14) by monocytes was observed (36). The glycoprotein was later found to be the soluble form of CD14: $\operatorname{sCD} 14$ (98, 285). In addition to macrophages, liver parenchymal cells are involved in the release of sCD14 $(322,383,505)$. The release of sCD14 by mononuclear cells and PMN is dose dependently induced by LPS and TNF- $\alpha$, whereas IFN- $\gamma$ and IL- 4 inhibit the release of sCD14 $(291,477)$. In the steady state, the concentration of $\mathrm{sCD} 14$ is 2 to $6 \mu \mathrm{g} / \mathrm{ml}$ in human serum (528). In septic shock patients, sCD14 levels are increased, the levels have been found to correlate with mortality (292). Active soluble CD14 was also found in human milk at 10-fold-higher concentrations than in serum. The milk sCD14 may play a role in the bacterial colonization of the gut (286).

Endothelial and epithelial cells do not express membrane 
CD14 and become up to 10,000-fold more sensitive to LPS in the presence of serum (Fig. 4). The LPS sensitivity can be blocked by anti-CD14 or by immunodepletion of sCD14 from the serum $(150,566)$. Presentation of sCD14-LPS to endothelial or epithelial cells results in up regulation of adhesion molecules, excretion of IL-6 and IL-8, and endothelial damage $(150,433,566,616)$ The role of LBP in the transfer of LPS to sCD14 is unclear (433).

In addition to its proinflammatory actions, sCD14 exerts anti-inflammatory actions. First, it accelerates the LBP-mediated transfer of LPS to HDL, but it has been found to be inessential in this process $(599,612)$. Second, injection of sCD14 into LPS-challenged mice is protective against LPSinduced death (204), although in a similar experiment by Stelter et al., sCD14 provided less protection, with significant decreases in mortality but not in cytokine release and organ damage (503). In both experiments, the amount of sCD14 injected was approximately 25 -fold greater than the endogenous sCD14 levels. In vitro experiments revealed that moderate concentrations of sCD14 enhanced the LPS-induced activation of monocytes, macrophages, and PMN (183, 533) whereas inhibition of LPS-induced activation was observed at higher sCD14/LBP ratios $(203,477,533)$.

\section{Toll-Like Receptors}

Due to the absence of a transmembrane signaling domain in CD14 and the necessity for a signaling receptor for sCD14, the presence of an additional molecule involved in LPS binding and signaling was expected. This putative signaling receptor was found after the cloning of the defective gene in the LPSunresponsive $\mathrm{C} 3 \mathrm{H} / \mathrm{HeJ}$ and $\mathrm{C} 57 \mathrm{BL} / 10 \mathrm{ScCr}$ mice (428, 430, 441). This molecule turned out to be Toll-like receptor 4 (TLR4), named after the homologous Toll protein in Drosophila melanogaster $(359,439)$. The putative signaling pathway components in mammals and Drosophila are CD14 $\rightarrow$ TLR4 $\rightarrow$ MyD88 $\rightarrow$ IRAK $\rightarrow$ TRAF6 $\rightarrow$ IкB $\rightarrow$ NF-кB for inflammatory mediators and Spàtzle $\rightarrow$ Toll $\rightarrow$ Tube $\rightarrow$ Pelle $\rightarrow$ dTRAF $\rightarrow$ Cactus $\rightarrow$ Dorsal for antimicrobial peptides, where IRAK is IL-1R-associated kinase and TRAF6 is TNF receptorassociated factor $6(49,439)$. To date, TLR1 to TLR10 have been identified and are all expected to be involved in immune responses $(63,376,400 \mathrm{a})$. The TLRs, the IL-1 receptor, the IL-18 receptor, and a number of mammalian and nonmammalian proteins exhibit a striking similarity with respect to the Toll/IL-1 receptor domain (TIR); hence, this family of receptors is called the TIR superfamily (400a). Three major groups can be determined: the immunoglobulin domain subgroup, containing the IL-1RI and the IL-18R; the leucine-rich-repeat subgroup, containing the TLRs; and the adaptor subgroup, which includes the MyD88 protein essential for TLR2 and TLR4 mediated signaling (400a).

So far, the specificities of TLR2, TLR3, TLR4, TLR5, and TLR9 (partially) have been shown to be involved in recognition of microbial components. A substantial amount of data suggests that TLR4 is involved mainly in the recognition of LPS from gram-negative bacteria. TLR2 recognizes gram-positive cell wall constituents such as PGN and LTA but also recognizes microbial lipoproteins and lipopeptides and yeasts. In addition, TLR3 recognizes viral double-stranded RNA
TABLE 2. Microbial ligands of the TLRs

\begin{tabular}{|c|c|c|}
\hline Receptor & Origin & Microbial ligands \\
\hline \multirow[t]{12}{*}{ TLR2 } & Gram-positive bacteria & $\begin{array}{l}\text { Peptidoglycan }(478,611) \text { and } \\
\text { LTA (478) }\end{array}$ \\
\hline & Gram-negative bacteria & $\begin{array}{l}\text { LPS proteins }(216,301) \text {, LPS } \\
\text { from Leptospira interrogans } \\
(587) \text { and Porphyromonas } \\
\text { gingivalis }(22)\end{array}$ \\
\hline & Mycobacteria & $\begin{array}{l}\text { Lipoarabinomannan (356), cell } \\
\text { wall (538) and lipoproteins/ } \\
\text { lipopeptides (53) }\end{array}$ \\
\hline & Borrelia burgdorferi & $\begin{array}{l}\text { Lipoproteins/lipopeptides (215, } \\
320)\end{array}$ \\
\hline & Treponema spp. & $\begin{array}{l}\text { Glycolipids }(405,471) \text { and } \\
\text { lipoproteins/lipopeptides } \\
(320)\end{array}$ \\
\hline & Mycoplasma spp. & $\begin{array}{l}\text { Lipoproteins (320) and } \\
\text { lipopeptides (515) }\end{array}$ \\
\hline & S. aureus & $\begin{array}{l}\text { Phenol-soluble modulin from } \\
\text { S. aureus (184) }\end{array}$ \\
\hline & S. pneumoniae & Cell wall (611) \\
\hline & Group B streptococci & Soluble factor (GBS-F) (211) \\
\hline & Neisseria meningitidis & Porins (344) \\
\hline & Yeast (zymosan) & Complete cells (537) \\
\hline & Human protein & $\begin{array}{l}\text { Heat shock protein } 70(14, \\
541)\end{array}$ \\
\hline TLR3 & Virus & dsRNA (6) \\
\hline \multirow{8}{*}{ TLR4 } & Gram-negative bacteria & LPS $(221,428,441)$ \\
\hline & Gram-positive bacteria & LTA (514) \\
\hline & Mycobacteria & $\begin{array}{l}\text { Heat-sensitive compound } \\
\text { (357) }\end{array}$ \\
\hline & Chlamydia pneumoniae & Heat shock protein $60(55)$ \\
\hline & Respiratory syncytial virus & F protein $(282)$ \\
\hline & Treponema brennaborense & Glycolipids (471) \\
\hline & Human protein & Heat shock protein 60 (396) \\
\hline & Human protein & $\begin{array}{l}\text { Heat shock protein } 70(14, \\
541)\end{array}$ \\
\hline TLR5 & Bacteria with flagella & Flagellin (199) \\
\hline TLR9 & Bacteria & CpG DNA (210) \\
\hline
\end{tabular}

dsRNA, TLR5 recognizes bacterial flagellin, and TLR9 recognizes bacterial CpG DNA (references are given in Table 2). Of the remaining TLRs identified, TLR1 may function as an accessory receptor for TLR2 in the recognition of Neisseria meningitidis cell wall components, whereas other investigators observed the heterodimerization of the signaling domain of TLR2 with either TLR1 or TLR6, enabling the recognition of zymosan, group B streptococcal soluble factor, or gram-positive lipopeptides and lipoproteins $(211,407,516,603)$. In the response to $S$. aureus modulin, however, TLR1 inhibited and TLR6 enhanced the TLR2-mediated response, indicating a modulatory role for these proteins (184). This is confirmed by the findings of Spitzer et al., who observed the inhibition of TLR4-mediated responses by TLR1 in endothelial cells (494). A similar role could be envisioned for some other TLRs for which no microbial specificity has been determined.

Some contradictory results with regard to receptor specificities were obtained. The LTA-induced activation through TLR4 instead of TLR2 was also reported $(349,513)$, as well as the LPS-induced activation through TLR2 instead of TLR4 $(267,606)$. The latter has been clarified, because repurified 
LPS, totally devoid of associated endotoxin protein, activated cells through TLR4 but lacked TLR2 binding (216). However, LPS from Leptospira interrogans (587) and Porphyromonas gingivalis (22) have been found to act exclusively through TLR2. LPS from the LTA-induced activation through TLR2 was observed in overexpression experiments (478). In contrast, the lack of a response to LTA was observed in TLR4-deficient mice, whereas TLR2-deficient mice were responsive to LTA (513). Unidentified cofactors in the overexpression experiments may hamper the accurate characterization of ligand specificity, which is not the case for the knockout models (5).

The activation of cells by microbial components is dependent on CD14 (myeloid cells) or sCD14 (endothelial and epithelial cells). It has now been shown that the microbial components interact primarily with CD14 and subsequently with the TLRs. In fact, by using photoactivated cross-linking, it was shown that LPS becomes cross-linked to TLR4 and MD-2 only if the latter are coexpressed with CD14 (79). The extracellular protein MD-2 is closely associated with TLR4 and is essential for LPS binding to this receptor (487).

The role of SCD14 in TLR-mediated signaling has not been specifically addressed. In several of the TLR-overexpression studies in vitro, however, serum was found to enhance activation by the microbial components and the activation could be (partially) inhibited by the addition of anti-CD14 antibodies $(118,215,320)$. This reveals that SCD14 in serum can replace surface-bound CD14 and that CD14-mediated signaling is not significantly different in myeloid cells expressing membrane CD14 and other cell types that are dependent on sCD14. However, in deletion and substitution studies with membrane, CD14 and sCD14, the same binding site for LPS, but different sites for mCD14 and sCD14-mediated signaling were found $(502,563)$. Whether these differences actually reflect the involvement of distinct accessory receptors (e.g., TLRs) remains to be determined.

Human TLR4 is an 841-aa protein with a molecular mass of $92 \mathrm{kDa}$, whereas TLR2 is an $85-\mathrm{kDa}$ protein $(359,614)$. A structural similarity between CD14 and the TLRs is the presence of a leucine rich-repeat (LRR) in the extracellular domain. CD14 and TLR4 contain 10 and 21 of these LRR moieties, respectively, which suggests that both receptors may contain a similar binding site for LPS $(127,359)$. In contrast to TLR4, the binding site in CD14 is only partially situated in the LRR region $(248,250)$. An acyclic LPS agonist exhibited TLR4-mediated binding which was independent of LBP and (s)CD14, although sCD14 strongly enhanced the cellular response (318). In addition, the proximity of LPS-CD14-TLR4 prior to signaling has been illustrated (244). Poltorak et al. showed that $\mathrm{C} 3 \mathrm{H} / \mathrm{HeJ}$ macrophages (expressing a nonfunctional TLR4) transfected with either human or murine TLR4 responded differently to LA-14-PP (deficient in secondary acyl chains): whereas the cells transfected with murine TLR4 produced TNF- $\alpha$, the cells transfected with human TLR4 were not activated (429). The authors proposed that LPS physically interacts with TLR4, enabling this molecule to discriminate between lipid A and the partially deacylated LA-14-PP. Similarly, human THP-1 (CD14 $\left.{ }^{+}\right)$cells transfected with hamster TLR4 responded to Rhodobacter sphaeroides LPS whereas the same cells transfected with human TLR4 did not (319).

Several approaches using knockout mice or cell lines trans-

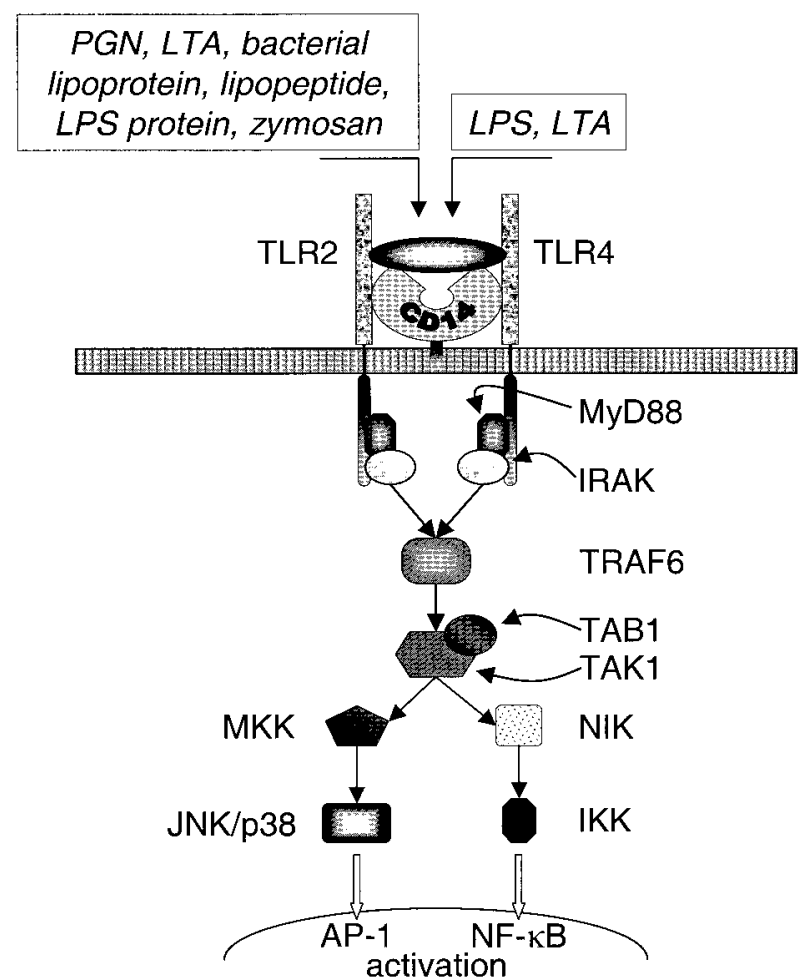

FIG. 5. TLR signaling pathways. The shared signaling pathway for TLR2 and TLR4 is depicted. IRAK, IL-1R-associated kinase; TRAF6, tumor necrosis factor receptor-associated factor 6; TAK1, transforming growth factor $\beta$-activated kinase; TAB1, TAK1-binding protein; NIK, NF- $\mathrm{BB}$-inducing kinase; MKK, mitogen-activated protein kinase kinase; JNK, c-Jun N-terminal kinase; IKK, IкB kinase; AP-1, activator protein 1 .

fected with mutated putative signaling proteins have pinpointed important participants in the signaling pathway. Defective proteins such as MyD88 $(255,513,515,614)$, IRAK $(607,614)$, TRAF $(607,614)$, and NIK (NF-кB-inducing kinase) (607), resulted in blocked or muted responses to grampositive and/or gram-negative cell wall constituents. In addition, similar experiments with knockout mice have identified MD-2 as essential accessory molecules in TLR4-mediated signaling and intracellular trafficking $(379,487)$, whereas MD-1 is instrumental in the LPS-induced B-cell proliferation and antibody production through RP105 $(380,394)$. A substantial part of the TLR2 and TLR4 signaling pathways coincides, but there is now increasing evidence that alternative pathways also exist. This is exemplified by the observation that Kupffer cells from MyD88-deficient mice release IL-18 but do not produce IL-1 $\beta$ and IL-12 while Kupffer cells from TLR4-deficient mice do not produce any of these cytokines after stimulation with LPS (481) (the signaling pathways of TLR2 and TLR4 are shown in Fig. 5).

The expression patterns of the TLRs vary widely, but whereas TLR1 transcripts are present in almost all myeloid and lymphoid cells, the TLR3 mRNA is present at substantial levels only in NK cells (Table 3) (219). TLR2 and TLR4 exhibit comparable expression patterns and in steady state are represented mainly on PMN, monocytes, macrophages, and dendritic cells $(376,377)$. However, both receptors are also present 
TABLE 3. Constitutive TLR mRNA expression patterns in human leukocytes ${ }^{a}$

\begin{tabular}{lccccc}
\hline & \multicolumn{5}{c}{ Expression of receptor in $^{b}$ : } \\
\cline { 2 - 6 } Receptor & $\begin{array}{c}\text { T-lympho- } \\
\text { cytes }\end{array}$ & $\begin{array}{c}\text { B-lympho- } \\
\text { cytes }\end{array}$ & $\begin{array}{c}\text { NK } \\
\text { cells }\end{array}$ & Monocytes & $\begin{array}{c}\text { Dendritic } \\
\text { cells }\end{array}$ \\
\hline TLR1 & + & + & + & + & + \\
TLR2 & \pm & - & - & + & - \\
TLR3 & - & \pm & + & - & - \\
TLR4 & - & - & - & + & - \\
TLR5 & + & - & + & \pm & - \\
TLR6 & \pm & + & + & \pm & \pm \\
TLR9 & - & - & - & - & + \\
\hline
\end{tabular}

${ }^{a}$ Data from reference 219 .

${ }^{b}$ All levels within one cell type are related to the highest level of TLR expression for that particular cell type. Of the listed cell types, $\mathrm{T}$ cells have the lowest expression levels and monocytes have the highest.

on various other cell types including epithelial and endothelial cells $(59,118,614)$; TLR2 is also present on hepatocytes $(323)$. In comparison to CD14, the number of TLR4 molecules on monocytes is small: CD14 is expressed at ca.115,000 molecules per monocyte whereas TLR4 is present at ca.1,300 molecules per monocyte, which has led some investigators to propose that TLR4 expression may be a limiting factor in the response to LPS $(9,564)$. The expression levels of TLR2 and TLR4 are modulated by LPS and other microbial components. During infection, TLR2 and TLR4 are expressed on cells otherwise expressing very low levels of these receptors. The treatment of rats with LPS, IL-1, or TNF results in a marked upregulation of TLR2 mRNA on macrophages, monocytes, liver parenchymal cells, and a variety of cells in other tissues (323, 348, 349, 564). TLR 4 mRNA levels on liver parenchymal cells, kidneys, and spleen was unchanged after an LPS challenge, whereas the levels were increased in the heart and lungs and decreased in the brain (349). Although LPS induces an increase in TLR4 mRNA in a number of cell types, surface expression of TLR4 is decreased on murine macrophages $(348,390)$ and human monocytes (47).

Recently, the expression of a splice variant of TLR4 in mice was observed, resulting in the presence of a soluble TLR4 in serum (239). The soluble TLR4 inhibited TNF- $\alpha$ release and $\mathrm{NF}-\kappa \mathrm{B}$ activation in macrophages, possibly representing a novel component involved in immunomodulation. Although the TLR4 is a link in a highly sensitive signaling pathway, the absence of this receptor corresponds to a decreased response to LPS, as expected, but also in an increased sensitivity to live gram-negative bacteria (440). However, Haziot et al. have shown that CD14- and TLR4-deficient mice and TLR2-deficient hamsters exhibit a highly efficient LPS- or $E$. coli-induced PMN infiltration into the peritoneum, resulting in increased clearance of bacteria (201). They propose a novel CD14-, TLR4-, TLR2-, complement-, and coagulation factor-independent pathway for the PMN response.

In addition to a direct role in innate immunity, several investigators have revealed a modulating role of the TLR pathway in the development of adaptive immune responses. MyD88-deficient mice were defective in the activation of antigen-specific Th1 immune responses (469), whereas the absence of TLR4 affected Th2 responses (77).

These data, taken together, indicate an important role for
TLRs in discrimination between a variety microbial components. Additional research must reveal the precise interactions between (s)CD14 and the TLRs, as well as the functions of the remaining TLRs in the innate immune response.

\section{$\boldsymbol{\beta}_{2}$-Integrins}

The CD18 antigens, or $\beta_{2}$-integrins, comprise a family of three closely related cell surface glycoproteins with a varying CD11 $\alpha$-chain and an identical CD18 $\beta$-chain: (i) $\alpha_{1} \beta_{2}$-integrin, LFA-1 or CD11a/CD18; (ii) $\alpha_{2} \beta_{2}$-integrin, CR3 (complement receptor), MAC-1, or CD11b/CD18; and (iii) $\alpha_{3} \beta_{2}$-integrin, CR4, p150,95, or CD11c/CD18. LFA-1 is expressed on all leukocytes; CR3 is expressed on monocytes, macrophages, $\mathrm{PMN}$, and lymphocytes; while CR4 is expressed abundantly on monocytes and macrophages (591). LFA-1 recognizes the adhesion molecules ICAM-1 and ICAM-2, CR3 recognizes surface-bound C3bi and surface-bound fibrinogen, and CR4 binds surface-bound fibrinogen as well $(591,598)$.

Many strains of E. coli are recognized by macrophages without the intervention of antibodies and complement. CD18 on the surface may be responsible for recognition of the bacteria: (i) Spreading of macrophages on a surface coated with antiCD18 antibodies prevents the binding of E. coli (593); (ii) spreading of macrophages on a surface coated with Re-LPS or lipid $\mathrm{IV}_{\mathrm{A}}$ prevents the binding of bacteria and C3bi-coated erythrocytes (593); (iii) LPS-coated erythrocytes (E-LPS) bind to macrophages in the absence of LBP, and the binding is proportional to the amount of LPS bound to the erythrocytes (593); and (iv) monocytes from CD18-deficient patients are unable to bind E-lipid $\mathrm{IV}_{\mathrm{A}}$, E-LPS, and unopsonized bacteria (594). Furthermore, all three members of the CD18 family are capable of binding LPS. The part of the LPS recognized by CD18 resides in the lipid A region because Re-LPS and the lipid $\mathrm{A}$ precursor lipid $\mathrm{IV}_{\mathrm{A}}$ are recognized. Since the acyl moieties of the LPS are embedded in the outer cell wall of the bacteria, only the phosphorylated glucosamines of lipid $\mathrm{IV}_{\mathrm{A}}$ are exposed; therefore, this is probably the moiety of the LPS molecule that is recognized by $\operatorname{CD} 18(593,594)$. This hypothesis is strengthened by the observation that Leishmania mexicana lipophosphoglycan, rich in phosphosugars, binds to the same site as LPS on CD18 (517). In addition, Blastomyces dermatidis yeasts, an acylpolygalactosyl from Klebsiella pneumoniae, and group A and B streptococci bind to CD11b/CD18, while $S$. aureus and Listeria monocytogenes bind CD11c/CD18 (76, 217, 358, 388). The binding site on the CD18 antigens for LPS is distinct from the binding site for endogenous ligands (594).

In several studies it was shown that the activation of mononuclear cells by several microbial antigens, including LPS, is partially inhibited by antibodies to CD18, CD11b, or CD11c, which may indicate that the $\beta_{2}$-integrins are involved in cellular activation $(76,358)$. CD11/CD18 and CD14 may have a common signaling pathway $(170,232,234)$. There are indications that CD11/CD18 also utilizes the TLR4 pathway for LPSinduced activation, albeit with substantially lower efficiency, as shown by the differences in activation kinetics $(233,420)$. Due to the lower efficiency of CD11/CD18-TLR4 than of CD14TLR4, the physiological relevance of the former is probably limited. Whether CD11/CD18 contributes to gram-positive 


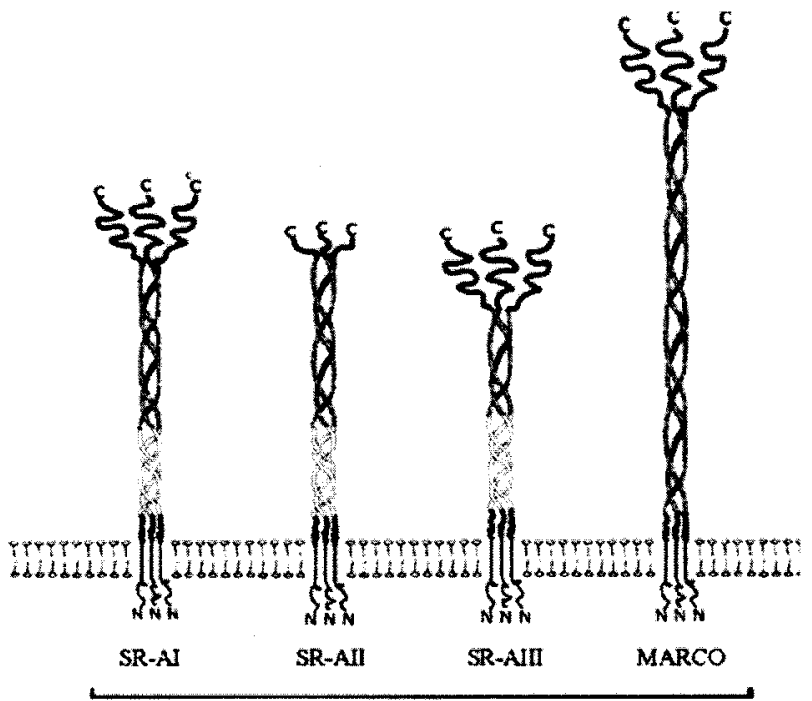

Class A

FIG. 6. Structure of the SR-As.

bacterium-induced activation through TLR 2 remains to be determined.

\section{Selectins}

The $\beta_{2}$-integrins are not the only adhesion molecules involved in the binding of LPS. Recently, Malhotra et al. showed that P-selectin and L-selectin are able to bind LPS $(335,337)$. In addition, L-selectin mediated the binding of LTA (395). In the absence of serum, anti-P-selectin antibodies almost fully inhibited the binding of fluorescein isothiocyanate-LPS to platelets, whereas antibodies to P-selectin and L-selectin significantly reduced the binding of fluorescain isothiocyanateLPS to PMN and the LPS-induced superoxide production by these cells $(335,337,395)$. It was proposed that L-selectin may represent the low-affinity serum-independent signaling receptor involved in the response to high concentrations of LPS (336).

\section{Scavenger Receptors}

Hampton et al. demonstrated that lipid $\mathrm{IV}_{\mathrm{A}}$ can bind to a class A scavenger receptor (SR-A). Binding to the SR-A resulted in uptake but not in activation of the cells and uptake was followed by dephosphorylation, which renders the lipid $\mathrm{IV}_{\mathrm{A}}$ less toxic $(185,186)$. The SR competitor polyinosinic acid, poly(I), reduced liver uptake of lipid $\mathrm{IV}_{\mathrm{A}}$ by approximately $35 \%$, indicating a considerable SR mediated binding to the liver (185). Besides LPS and E. coli, SR-A binds LTA and whole gram-positive bacteria like $S$. aureus, L. monocytogenes, and Mycobacterium tuberculosis (97, 173, 236, 416, 509, 619). The MARCO SR (for "macrophage receptor with collagenous structure"), which also belongs to the SR-A class, recognizes gram-negative and gram-positive bacteria $(107,544)$.

SR-A are trimeric transmembrane glycoproteins that are expressed by tissue macrophages (including Kupffer cells) and liver sinusoidal and aortic endothelial cells $(80,227,382)$. They consist of three extracellular C-terminal cysteine-rich domains connected to the transmembrane domain by a long fibrous, collagen-like stalk (Fig. 6). Three SR-A types have been identified, of which SR-AI and SR-AII are expressed on the plasma membrane (15). SR-AI contains a 110 -aa C-terminal cysteinerich sequence that is lacking in SR-AII (273). The C-terminal end of the collagenous domain is responsible for the binding of polyanionic ligands $(96,604)$. Besides the bacteria and bacterial components, SR-A recognize a broad range of ligands, including acetylated LDL, oxidized LDL, maleylated bovine serum albumin, poly(I), and poly(G) $(277,520)$. MARCO is very similar to SR-Al, hence its designation as an SR-A (Fig. 6). MARCO is homotrimeric and contains an extracellular collagenous domain and a C-terminal cysteine-rich domain (107). It lacks the $\alpha$-helical coiled coil present in SR-A and contains a much longer collagenous domain. The bacteriumbinding domain has been located immediately proximal to the cysteine-rich domain, which is similar to the analogous domain in SR-A (108).

Cross-competition studies with LPS and several other SR ligands have shown that there are also other SRs expressed on Kupffer cells and liver sinusoidal endothelial cells involved in the binding of LPS $(489,557)$. Little is known about the relative contribution of the SRs in the liver for the uptake of bacterial components. In in vivo experiments, blocking antibodies against MARCO did not affect the clearance of bacteria in mice, but this may partially be explained by the low constitutive expression levels of MARCO in the liver (544). The liver uptake of i.v.-injected LPS in SR-A-deficient mice was almost equal to that in control mice (E. S. van Amersfoort et al., unpublished results), but increased LPS levels were found in SR-A-deficient mice after i.p. injection (271). The in vitro binding of LPS to Kupffer cells, liver sinusoidal endothelial cells, and peritoneal macrophages from SR-A-deficient mice is significantly reduced compared to that to cells from wild-type mice, which shows that the SR-A does recognize LPS and does contribute to the binding and uptake of LPS (van Amersfoort et al., unpublished). Binding by scavenger receptors may actually form a protective mechanism by removing excess microorganisms or components, thus preventing binding to the highly sensitive CD14 receptor and the development of septic shock. Possibly, the constitutive expression levels of SR-A are not sufficient to unequivocally reveal the protective effect under normal, noninflammatory conditions. Injection of LPS into SR-A knockout and wild-type mice revealed no differences in the production of TNF- $\alpha$ (van Amersfoort et al., unpublished) (271). However, Haworth et al. showed that M. bovis BCGinfected SR-A knockout mice are more susceptible to LPS (198). In addition, Suzuki et al. and Ishiguro et al. observed that compared to wild-type mice, SR-A knockout mice were markedly more susceptible to live $L$. monocytogenes bacteria and to herpes simplex virus $(236,509)$. Besides a reduced phagocytosis of L. monocytogenes by SR-A knockout macrophages, the intracellular killing of the facultative, intracellular bacteria was also reduced, resulting in larger granulomas and increased mortality in the SR-A knockout mice (236).

Although the incubation of macrophages with LPS did not result in SR-mediated activation, several other studies reveal that SR ligands such as modified LDL or poly(I) may induce the release of IL-1 and TNF- $\alpha$, up regulation of urokinase-type 
plasminogen activator on macrophages, and up regulation of adhesion molecules on endothelial cells (185, 222, 247, 410, 411). In addition, Kobayashi et al. observed reduced IL-1 production in SR-A knockout mice after an LPS challenge and proposed that binding of LPS to SR-A induces the release of IL-1 (271). However, no additional (in vitro) data to support this hypothesis were provided.

Based on available data, SR-A can be considered anti-inflammatory due to the uptake of LPS or other bacterial compounds, circumventing the CD14-TLR signaling pathway. LPS affect the expression of the SR-A. On human macrophages, the expression of SR-A decreases after stimulation with LPS (553). Similarly, the SR-A mRNA is transiently down regulated after an in vivo challenge with LPS in mice (461). However, treatment of mice with inflammatory stimuli like BCG or heatkilled Corynebacterium parvum results in increased expression on liver Kupffer cells $(181,198,523)$. Also, the expression of MARCO can be upregulated by inflammatory stimuli; in mice, treatments with $\mathrm{BCG}, C$. parvum, $K$. pneumoniae, and LPS all resulted in a marked upregulation of MARCO expression in the liver $(181,544,545)$. Moreover, a similar pattern of high MARCO expression was observed in the livers of two newborns who died of sepsis (108).

\section{Moesin}

A 78-kDa LPS-binding protein was shown to be identical to moesin (membrane-organizing extension spike protein) (529). An anti-moesin antibody completely inhibited the LPS-induced TNF release by monocytes, but LPS binding was not blocked (529). Due to the complete inhibition of LPS-mediated signaling by the anti-moesin antibody, whereas an antiCD14 antibody only partially blocked responses, it is tempting to speculate that moesin may represent an element in the CD14-TLR4 signaling pathway. The fact that the anti-moesin antibody does not inhibit $S$. aureus-mediated inhibition precludes the binding of the antibody to TLR2 but not to TLR4.

\section{Heptose-Specific Lipopolysaccharide Receptor}

A receptor on liver parenchymal cells was identified that specifically recognized heptose residues in the inner core of LPS (412). This receptor may be involved in the transfer of LPS from the circulation to bile as proposed by Van Bossuyt et al. (542).

\section{LIPOPOLYSACCHARIDE- AND LIPOTEICHOIC ACID-BINDING PROTEINS}

\section{Neutrophilic Lipopolysaccharide-Binding Molecules}

Bactericidal/permeability-increasing protein. In 1978, Weiss et al. reported the isolation of a potent bactericidal protein, BPI, from human PMN (583). The cationic, 55-kDa protein resided in the azurophilic granules of PMN and, to a lesser extent, in monocytes and macrophages. It binds highly specifically to gram-negative bacteria and kills bacteria by increasing the permeability of the outer membrane and by activating cell wall-degrading outer membrane enzymes $(110,583)$. No bactericidal activity of BPI against gram-positive bacteria was observed (583). The initial effect of the decreased integrity of the outer membrane of gram-negative bacteria is growth arrest ( $<1 \mathrm{~min}$ ) followed by changes in the cytoplasmic membrane, resulting in impaired energy metabolism, irreversible growth arrest, and, finally, death $(109,583)$. The bactericidal activities of other granule constituents such as the p15s and defensins are synergistic with that of BPI $(311,577)$, but the serum protein LBP may also enhance the bactericidal activity of BPI (220). PMN may also excrete BPI, and excreted BPI has identical bactericidal effects to intracellular BPI (109). Binding of BPI to gram-negative bacteria is mediated by LPS. The initial interaction probably involves negatively charged groups in the inner core and lipid A and additional interactions with the hydrophobic moieties of lipid A, resulting in a high-affinity binding $\left(K_{d}=2\right.$ to $\left.5 \mathrm{nM}\right)(159,160,401)$. In vitro experiments with BPI have shown that the sensitivity of various gramnegative species to the bactericidal effect of BPI varies considerably. Strains expressing rough LPS are more sensitive than strains expressing smooth LPS. Limited proteolysis of BPI yields a C-terminal $30-\mathrm{kDa}$ fragment and an N-terminal 25$\mathrm{kDa}$ fragment (401). The latter contains the LPS-binding and bactericidal capacity $(401,402)$. The $25-\mathrm{kDa}$ fragment, a recombinant $23-\mathrm{kDa}$ N-terminal fragment $\left(\mathrm{rBPI}_{23}\right)$, and holoBPI have comparable affinities for free LPS, irrespective of the serotype (401).

Binding of BPI to LPS neutralizes the biological activity of LPS in vitro. BPI attenuates LPS-mediated endothelial damage and IL-6 production as well as LPS-mediated NO, TNF- $\alpha$, IL-1, IL-6, and IL-8 production by macrophages and whole blood $(11,67,91,362,584)$. In vivo, BPI or BPPI $_{23}$ reduced LPS- or bacterium-induced $\mathrm{TNF}-\alpha$ release, liver damage, $\mathrm{NO}$ production, and mortality and protected against cardiovascular depression $(7,117,275,321)$. Combining rBPI with antibiotics enhances its protective effect (7). BPI causes a significant reduction in serum LPS, TNF, IL-6, IL-8, and IL-10 levels and in several other parameters in healthy volunteers (567). The results of a clinical study of children with meningococcal sepsis were promising: of 26 patients only 1 died (4\%), which was favorable compared to the predicted mortalities, which varied between 15 and $49 \%$ based on various parameters such as LPS levels, serum IL-6 levels, etc. (167). However, in a larger placebo-controlled study, the mortality in the $\mathrm{rBPI}_{21}$-treated patients was not significantly reduced, although there was a trend toward improved outcome in the primary outcome variables (309). The feasibility of the use of BPI for the treatment of sepsis and septic shock in humans may be restricted due to the limited half-life of approximately $10 \mathrm{~min}$ in vivo $(28,29)$.

CAP18. Like BPI, CAP18 was isolated from PMN, but the $18-\mathrm{kDa}$ protein bears no structural and sequence similarity to BPI and other LPS-binding proteins (297). CAP18 binds LPS but is also bactericidal to bacteria such as E. coli and $S$. aureus (381). Defensins, lactoferrin, and lysozyme synergistically enhance the bactericidal activity of $\operatorname{CAP} 18(23,381)$. The production of CAP18 by human lung epithelial cells and the release of CAP18 onto the airway surface of the cells indicate that it may also have a function in mucosal defense (23). Intratracheal instillation of CAP18-adenovirus reduced the response to Pseudomonas aerigunosa, whereas i.v.-injected virus protected against LPS and E. coli (24). The LPS-binding site resides in the $\mathrm{C}$-terminal 36-aa part of the molecule, and pep- 
TABLE 4. Physical properties and composition of human plasma lipoproteins ${ }^{a}$

\begin{tabular}{lcccc}
\hline \multicolumn{1}{c}{ Property } & Chylomicrons & VLDL & LDL & HDL \\
\hline Density (g/ml) & 0.95 & $0.95-1.006$ & $1.019-1.063$ & 2.3 \\
Mol mass (/10 $\left.{ }^{6} \mathrm{Da}\right)$ & \pm 400 & $10-80$ & $18-25$ & $0.17-0.36$ \\
Diam (nm) & $75-1200$ & $30-80$ & $5-15$ & $5-12$ \\
Composition (\%, wt/wt) & $80-95$ & $55-80$ & $20-25$ & $5-10$ \\
$\quad$ Triglycerides & $3-9$ & $10-20$ & $40-50$ & $20-30$ \\
Phospholipid & $2-7$ & $5-15$ & B100 & A-I, AII, A-IV \\
Total cholesterol & A-I, A-II, A-IV & B100 & C-I, C-II, C-III \\
Apolipoproteins & B48 & C-I, C-II, C-III & E \\
& C-I, C-II, C-III & E & &
\end{tabular}

${ }^{a}$ Data from reference 166.

tides containing this region show similar anti-inflammatory effects to intact CAP18 $(264,295,296,545 a)$.

CAP37. CAP37 is a glycoprotein with a molecular mass of 29 to $37 \mathrm{kDa}$ (418); it is bactericidal to gram-negative and grampositive bacteria such as E. coli, S. enterica serovar Typhimurium, S. aureus, and S. pneumoniae (418). In addition, CAP37 (also called heparin-binding protein) binds LPS, is chemotactic to monocytes, opsonizes $S$. aureus for phagocytosis by monocytes, enhances the LPS-induced activation of monocytes, and stimulates protein kinase $\mathrm{C}$ activity in endothelial cells $(207,208,418,419)$. A CAP37 $20-44$ peptide, containing the bactericidal and LPS-binding site, inhibited the LPS-induced hemodynamic changes, leukopenia, TNF-release, and mortality in rats (50).

Lactoferrin. Lactoferrin is an $80-\mathrm{kDa}$ glycoprotein that is present in neutrophilic granules, milk, and mucosal secretions (35). It binds LPS and is bacteriostatic to bacteria, indirectly through chelation of iron ions and directly through destabilization of the gram-negative bacterial cell membrane $(35,106)$. Lactoferrin is a major LPS-neutralizing compound produced and excreted by stimulated PMN (10, 56, 573). Lactoferrin peptides containing the LPS-binding site prevent the LBPmediated binding of LPS to CD14, which results (105) in a reduction of TNF and IL-6 release by THP-1 cells in vitro (104, 351). However, Baveye et al. demonstrated that lactoferrin binds to sCD14 and sCD14-LPS complexes, inhibiting the activation of endothelial cells and the resultant expression of adhesion molecules (34). A peptide containing the $\mathrm{N}$-terminal first 33 aa of lactoferrin potently inhibited TNF release by RAW264.7 in vitro, TNF release in vivo, and LPS lethality (615). Germ-free piglets that were fed lactoferrin were less sensitive to LPS, as shown by reduced mortality and hypothermia (304).

Lysozyme. Ohno and Morrison have shown that LPS binds to lysozyme and that the binding inhibits the immunostimulation of B cells. All LPS serotypes were shown to bind to lysozyme. However, conflicting data were obtained on the ability of lysozyme to affect cytokine release $(397,398,510,511)$.

\section{Other Lipopolysaccharide-Binding Proteins}

A number of other LPS-binding proteins have been characterized. Surfactants A and D bind to LPS and whole bacteria and may thus inhibit the binding of LPS to alveolar macrophages $(46,467,559)$. Serum amyloid P (SAP) binds LPS and inhibits the LPS-induced activation of PMN in vitro (87). In addition, SAP peptides that bind LPS inhibit cell activation in whole blood (87). In contrast to these anti-inflammatory actions, SAP prevents the LPS-induced complement activation through the classical pathway and dose-dependently inhibits the neutralization of LPS by HDL, suggesting that under physiological conditions in the presence of serum, SAP mainly plays a proinflammatory role $(86,88)$. Other naturally occurring LPS-binding proteins are albumin (153), transferrin (37), and hemoglobin (464). Several apolipoproteins have been reported to bind LPS. These are addressed in the section on lipoproteins (see below).

\section{Development of Bactericidal and Lipopolysaccharide-Neutralizing Peptides}

Many investigations of LBP have been performed with the ultimate goal of creating a neutralizing LPS-binding structure applicable in the clinic to treat septic patients. Therefore, structural similarities between LBP have been studied, enabling the identification of specific requirements for LPS and LTA binding (260). Two similarities between lipid A-binding proteins are rather consistent: a net positive charge and a hydrophobic region in the LPS- or LTA-binding pocket (260). Peptides based on BPI (172), LBP (78), CAP18 (264), CAP37 (50), lactoferrin (615), SAP (87), Limulus anti-LPS factor (LAL) (451), bee melittin $(479,480)$, silk moth cecropin (479, 480 ), and the antibiotic peptide polymyxin B (238) have been constructed and tested on bactericidal, LPS- or LTA-binding, and neutralizing potency in vitro and in vivo. The results with these peptides with respect to binding, neutralization, and bactericidal activity are promising, but it was shown that the spatial organization of the positive and hydrophobic moieties largely determines the binding affinity of the peptides for the bacterial compounds $(238,354)$. Further investigations are needed to determine an optimal structure and may lead to the construction of a potent and highly specific peptide-based antibiotic and LPS- and LTA-neutralizing peptide.

\section{LIPOPROTEINS}

\section{Metabolism}

Lipoproteins are spherical macromolecular particles composed of a core containing hydrophobic cholesteryl esters and 
triglycerides surrounded by a shell of phospholipids, unesterified free cholesterol, and one or more proteins called apolipoproteins. The cholesterol and apolipoproteins stabilize the particles, but the apolipoproteins are also involved in lipid recruitment, modulation of enzyme activity, and modulation of receptor-mediated binding and endocytosis. In human blood, four major lipoprotein classes can be distinguished according to their density: chylomicrons, VLDL, LDL, and HDL. These lipoprotein classes differ with respect to size, electrophoretic mobility, and lipid and apolipoprotein composition (Table 4) (166). Two major metabolic routes can be distinguished: an exogenous pathway is involved in the transport and metabolism of intestinally derived dietary lipids, and an endogenous pathway is involved in the transport and metabolism of processed lipids. In short, dietary lipids that are absorbed in the intestines are packaged into chylomicrons, large triglyceriderich particles, and transported from the lymph to the blood circulation (333). On entering the circulation, lipoprotein lipase (LPL) processes the chylomicrons, delivering free fatty acids to peripheral tissues (fat and muscle tissue), whereas the cholesterol-rich core remnants are taken up mainly via ApoEspecific recognition sites on liver parenchymal cells (333). The liver secretes ApoB100-containing VLDL that in the circulation becomes enriched in ApoC and ApoE. These particles are also rich in triglycerides and serve as a source of free fatty acids for extrahepatic tissues. LPL and hepatic lipase (HL) process these particles, resulting in a loss of triglycerides, phospholipids, ApoC, and ApoE. The remnants (also called intermediatedensity lipoproteins [IDL]) are further processed to become LDL with ApoB100 as its sole apolipoprotein. These cholesterol-rich particles are taken up in the liver and peripheral tissues through the LDL receptor. To maintain cholesterol homeostasis, excess cholesterol in extrahepatic tissues must be returned to the liver, which is the only organ capable of disposing of cholesterol via the bile. This process is known as reverse cholesterol transport and involves the last lipoprotein particle, HDL. The enzyme lecithin:cholesterol acyltransferase promotes the esterification of cholesterol in HDL, creating a concentration gradient and thus facilitating the efflux of free cholesterol from extrahepatic tissues to HDL. In exchange for triglycerides, cholesteryl ester transfer protein-mediated transfer of cholesteryl esters to LDL and VLDL occurs. Subsequently, these particles are taken up by the liver. In addition, direct transfer of cholesteryl esters from HDL to the liver occurs through recognition by SR-BI. In contrast to the receptor-mediated uptake of VLDL and LDL, SR-BI promotes only the selective transfer of cholesteryl ester without causing the uptake of the HDL particle (2).

\section{Apolipoprotein E}

ApoE was identified in 1973 as a component of triglyceriderich VLDL and was initially referred to as arginine-rich protein due to its relatively high arginine content compared to other apolipoproteins known at that time (490, 540). The ApoE molecule is synthesized as a 317 -aa prepeptide after cotranslational cleavage yielding a 299-aa protein with a molecular mass of $34.2 \mathrm{kDa}$. ApoE is synthesized in a wide variety of tissues, including the liver, central nervous system, kidneys, adrenal glands, testes, and ovaries, but not the intestines (111,
496). However, the highest levels of ApoE mRNA are found in the liver parenchymal cells and the second highest are found in the astrocytes in the brain. Furthermore, ApoE is also produced by macrophages from the liver, lungs, and spleen (12, 26). In the absence of lipids, ApoE self-associates to form tetramers over a wide concentration range (580). In contrast, self-association does not occur on lipid surfaces. ApoE contains two domains that are joined by a protease-susceptible hinge region. Thrombin digestion of ApoE yields two fragments, of which the $10-\mathrm{kDa}$ C-terminal fragment harbors the lipid-binding domain whereas the LDL receptor (LDLr)-binding domain is situated in the 22-kDa N-terminal fragment (235, 581). The N-terminal domain contains four antiparallel helices, of which helix 4 contains the LDLr-binding domain. This helix is unusually rich in basic amino acids (Arg, Lys, and His). ApoE contains two heparin-binding sites, of which one is located within the LDLr-binding site (582). Similarly, ApoE interacts with heparan sulfate proteoglycans (HSPG). HSPG are abundantly present on many different cell types, including vascular endothelial cells and liver parenchymal cells within the space of Disse (605). In the liver, HSPG may be involved in both the secretion of ApoE and the binding of lipoproteinbound ApoE (243).

Several physiological and pathological functions for apoE have been proposed. These include the role of ApoE in lipid metabolism (as described above), intracellular lipid redistribution (281, 448), atherogenesis (75, 463, 549), neurobiology (nerve regeneration, association of the ApoE4 serotype with neuropathologic lesions in Alzheimer's disease) $(342,580)$, and immunomodulation (inhibition of proliferation of peripheral blood mononuclear cells and lymphocyte activation; inhibition of TNF secretion by glial cells) (20, 228, 299, 364, 399, 417).

\section{Anti-Inflammatory Role}

Ulevitch et al. were the first to observe that if LPS is mixed with serum or plasma, a decrease in buoyant density results. Preincubation of LPS with plasma decreased the ability of LPS to induce neutropenia and a pyrogenic response in rabbits. Further investigations showed that the LPS was bound to HDL and that a plasma protein aided in the binding $(525,534,536)$. In rabbits, the uptake of LPS by the adrenal glands was increased after LPS binding to HDL, which indicates that binding of LPS to HDL results in a decreased recognition by LPS receptors $(347,372)$. Since then, in vivo and in vitro experiments have shown that LPS and LTA bind to and are neutralized by lipid emulsions (177, 445), chylomicrons (194, 195, 447), VLDL (102, 194, 459, 464, 576), LDL (102, 177, 366, 459, 464, 554, 576), Lp(a) (385), HDL (102, 144, 177, 374, 459, 464, $535,576)$, ApoA-I $(112,135,539)$, ApoB $(112,464)$, and ApoE (449, 555).

In vivo experiments have shown that the injection of LPSHDL complexes may affect the decay of LPS in serum (144, 375 ) and inhibits the LPS-induced release of cytokines compared to LPS alone $(194,536)$. In addition, in several experiments the infusion of recombinant HDL (rHDL), VLDL, or lymph-derived chylomicrons and lipid emulsion also resulted in inhibition of LPS-induced physiological changes (120, 195, 226, 310, 445). Pajkrt et al. infused rHDL into humans, who 
TABLE 5. Inhibitory effects of lipoproteins on LPS and LTA toxicity

\begin{tabular}{|c|c|c|c|c|c|c|c|c|}
\hline \multirow[b]{2}{*}{ LPS and LTA property } & \multicolumn{7}{|c|}{ Effect of: } & \multirow[b]{2}{*}{ Reference(s) } \\
\hline & HDL & rHDL & LDL & $\begin{array}{l}\text { VLDL or } \\
\text { chylomicrons }\end{array}$ & $\begin{array}{l}\text { Emul- } \\
\text { sion }\end{array}$ & $\begin{array}{l}\text { Total lipo- } \\
\text { protein }\end{array}$ & ApoE & \\
\hline \multicolumn{9}{|l|}{ In vivo } \\
\hline Inhibition of cytokine release & & $\downarrow$ & & $\downarrow$ & & $\downarrow$ & $\downarrow$ & $\begin{array}{l}60,72,120,195,225,226,437, \\
555^{a}\end{array}$ \\
\hline Decreased pyrogenicity & $\downarrow$ & & & & & $\downarrow$ & & 534,535 \\
\hline Decreased mortality after LPS challenge & $\downarrow$ & $\downarrow$ & $\downarrow$ & $\downarrow$ & $\downarrow$ & $\downarrow$ & $\downarrow$ & $120,194,195,310,445,555$ \\
\hline Decreased mortality and TNF release after CLP ${ }^{b}$ & & & & $\downarrow$ & & & & 446 \\
\hline Increased excretion of ${ }^{125}$ I-LPS into bile & & & & $\downarrow$ & & & & 447 \\
\hline Decreased Kupffer cell binding & & & & & & & $\downarrow$ & 449 \\
\hline \multicolumn{9}{|l|}{ In vitro } \\
\hline $\begin{array}{l}\text { Inhibition of macrophage or monocyte activation } \\
\text { (cytokine release) }\end{array}$ & $\downarrow$ & $\downarrow$ & $\downarrow$ & $\downarrow$ & $\downarrow$ & $\downarrow$ & & $\begin{array}{l}30,60,61,135,136,177,196 \\
\quad 306,415,545,554,579\end{array}$ \\
\hline Inhibition of PMN priming & $\downarrow$ & & & & & & & 568 \\
\hline Inhibition of VCAM-1 expression by HUVEC ${ }^{c}$ & & $\downarrow$ & & & & & & \\
\hline Inhibition of LAL activation & $\downarrow$ & & $\downarrow$ & $\downarrow$ & & & & $103,112,193$ \\
\hline
\end{tabular}

${ }^{a}$ E. S. van Amersfoort et al., unpublished results.

${ }^{b}$ CLP, cecal ligation puncture; this experimental procedure results in polymicrobial peritonitis and sepsis.

${ }^{c}$ HUVEC, human umbilical vein epithelial cells.

were subsequently challenged with a low dose of LPS and observed a significant reduction in the release of proinflammatory cytokines and a partial reduction in the activation and/or release of components involved in coagulation (408, 409). The in vitro data mainly parallel those found in vivo. These data confirm that binding of LPS to lipoproteins decreases its ability to activate macrophages and endothelial cells (30, 57, 60, 196, 306, 366, 415, 554, 579) (Table 5). Recently, Grunfeld et al. have shown a similar inhibitory effect of lipoprotein binding on LTA-induced activation of macrophages (177). The inhibition of LPS-induced activation is dependent largely on the concentration of lipoproteins: in the presence of low concentrations of lipoproteins, cells become activated before neutralization by lipoproteins occurs (386). It has been shown that a 5-min exposure to LPS is sufficient to maximally bind and stimulate monocytes in whole blood, which implies that in the circulation neutralization by (infused) lipoproteins is a rapid process (157). However, Kitchens et al. illustrated that lipoproteins can remove LPS bound to the cell surface. This transfer is dependent on the presence of $\mathrm{sCD} 14$ and further enhances the protective effect of lipoproteins (269).

Mice with high HDL levels due to overexpression of human ApoA-I levels and rats rendered hyperlipidemic by estradiol treatment are less sensitive to LPS compared to the respective controls $(120,310)$. Hypercholesterolemic rabbits exhibited higher TNF- levels and mortality than did the normolipidemic controls (54). LDL receptor knockout mice, with cholesterol levels twice those in C57BL/6 mice, are less susceptible to LPS than are wild-type mice, as shown by decreased mortality and reduced release of TNF, IL-1, and IL-6 (387). In contrast, the severely hypercholesterolemic ApoE knockout mice were more sensitive to LPS (84). It is likely that the lack of ApoE is the cause of this increased sensitivity.

The binding of LPS to HDL is mediated by LBP and SCD14, although only the first has been shown to be essential (600, 602). Wright et al. showed that most LBP is associated with ApoA-I-containing particles, which may explain the preferential binding of LPS to HDL $(414,600)$. PLTP may also aid in the transfer of LPS to HDL (182). This was confirmed by observations that both LBP and PLTP could extract LPS from gram-negative bacterial cell membranes and mediate the transfer to lipoproteins (mainly HDL) (562). However, experiments by Vreugdenhil et al. indicated that LBP is associated mainly with ApoB-containing lipoproteins (e.g., LDL) (569). They have shown that the association of LBP with ApoB is stronger than with ApoA-I, that LBP in serum is present mainly on LDL and VLDL, and that LDL- and VLDL-associated LBP enhanced LPS binding to these lipoproteins. Using a solidphase binding assay, they also observed that in the absence of LBP, LPS preferentially bound to LDL and VLDL. The discrepancies in the results of Wright et al. (600) and Vreugdenhil et al. (569) may be explained by the differences in the methods used. Whereas the first group used affinity chromatography with either anti-ApoA-I or anti-LBP antibodies to coprecipate ApoA-I and LBP, Vreugdenhil et al. employed agarose gel electrophoresis in combination with immunoblotting to detect LBP-containing lipoproteins. In our in vivo and in vitro experiments, we have observed LPS and LTA binding to all lipoproteins in the serum, which may indicate that LBP transfers LPS and LTA to all lipoproteins (van Amersfoort et al., unpublished). However, although we observed binding to all lipoprotein classes, based on lipid or protein contents LTA seemed to exhibit preferential binding to HDL (Van Amersfoort et al., unpublished). Other investigators have also observed either preferential binding of LPS to HDL $(375,464,535)$, to LDL and/or VLDL $(102,554)$, or to all lipoproteins $(102,459,554$, $562,576)$ depending on the lipid and/or protein distribution in the distinct lipoprotein fractions. A correlation between the cholesterol contents of the lipoprotein fractions and LPS association was proposed by Van Lenten et al. (554), but with rHDL the neutralizing potency correlates with the phospholipid contents of the particle (72). Using the synthetic LPS-like antagonist E5531, it was found that association with the different lipoproteins did correlate with protein (HDL), cholesterol (VLDL, LDL), and triglyceride (VLDL) contents, which may imply that factors other than the composition of the li- 

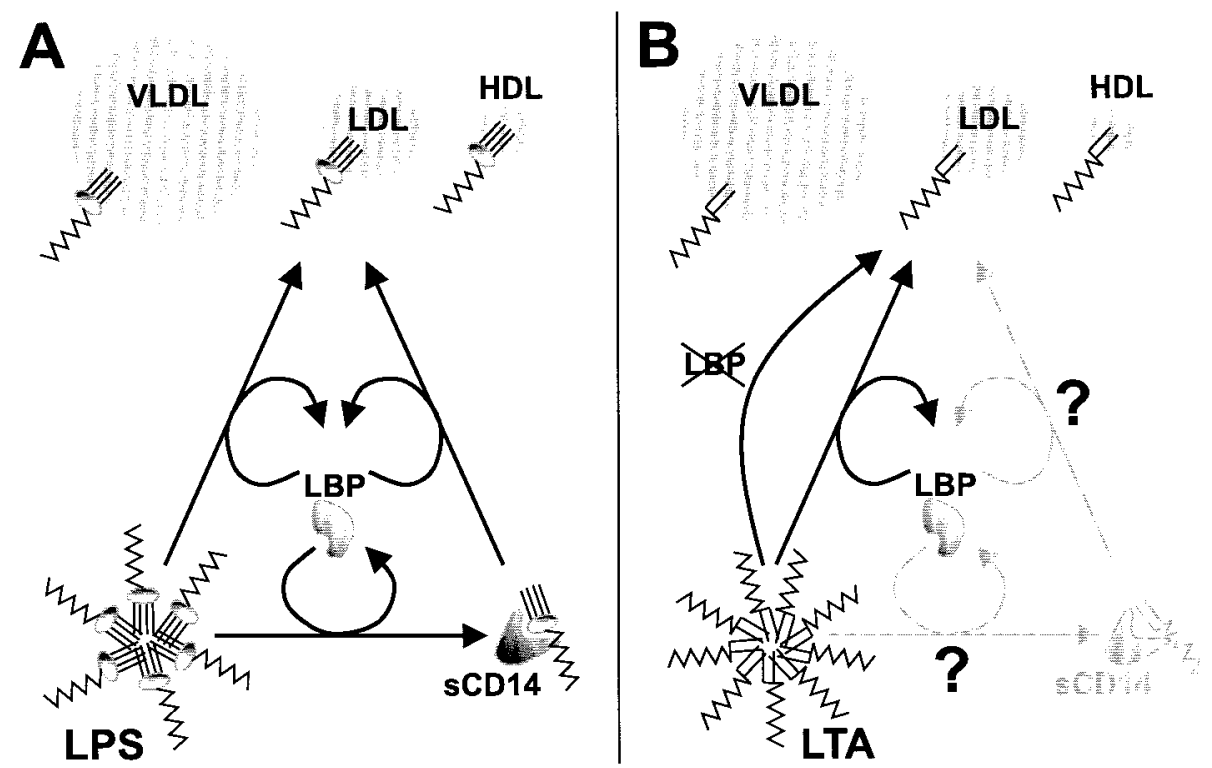

FIG. 7. LPS and LTA transfer to lipoproteins. Black arrows indicate established pathways. In contrast to LPS (left), LTA may also associate with lipoproteins in the absence of LBP (extra arrow in right panel).

poproteins are also involved $(459,576)$. The association with the lipoproteins in sera from mouse strains with various lipoprotein profiles correlates with the cholesterol contents of LDL and VLDL but not of HDL (van Amersfoort et al., unpublished). The increased binding of LTA to HDL that we have observed may be caused by the involvement of LBP in the transfer of LTA to HDL, as proposed by Grunfeld et al. (177). The proposed LPS and LTA neutralization pathways are depicted in Fig. 7.

The lipoprotein distribution of LPS may depend on the type of LPS used, the origin of the serum (animal species and lipoprotein status), or, when using plasma, the type of anticoagulant used (e.g., citrate, EDTA, or heparin) (101, 102, 554). Furthermore, as mentioned above, the use of a density gradient, agarose gel electrophoresis, or column chromatography may introduce additional variations.

So far, only the binding of LPS to lipoproteins has been discussed, but binding to apolipoproteins has also been reported. Emancipator et al. and Usynin et al. have shown that both ApoB and ApoA-I are able to bind and neutralize LPS $(112,539)$. Our group has shown that LPS binds ApoE and causes a redistribution in vivo, reducing the uptake by Kupffer cells and promoting the binding to liver parenchymal cells (449). In addition, we have shown that ApoE binds LTA, resulting in a similar redistribution from Kupffer cells to liver parenchymal cells and in a strongly decreased TNF release in vivo (Van Amersfoort et al., unpublished).

\section{Lipid Metabolism and Infection}

Injection of LPS or bacteria leads to a marked hyperlipidemic response, caused primarily by an increase in the level of VLDL triglycerides (470). Remarkably, the underlying mechanisms differ with the dose of LPS administered to the animal. With low doses, an increase in hepatic triglyceride production occurs, whereas at high doses of LPS $(>500 \mu \mathrm{g} / \mathrm{kg}$ of body weight), a decrease in the clearance of triglyceride-rich lipoproteins occurs (125). Experiments with IL-1 receptor antagonist (IL-1ra) and TNF antibodies showed that these phenomena could be only partially mimicked by administration of IL-1 or TNF- $\alpha$ (125). Subsequently, it was shown that $\alpha_{1}$ adrenergic receptors were involved in the low-dose-LPS-induced increase in triglyceride production whereas the $\alpha_{2}$-adrenergic receptors were involved in the high-dose-LPS-induced inhibition of LPL activity, confirming a partial cytokine-independent pathway (391). LPS and the proinflammatory cytokines induced by LPS affect a wide range of enzymes and receptors involved in lipid metabolism, which include LPL, hepatic lipase, PLTP, LRP, and LDL receptor (Table 6).

However, the extent and kinetics of the effects differed widely among these species and in some cases were even contradictory. This is not surprising since there are substantial species-specific differences in lipid metabolism, resulting in marked differences in lipoprotein profiles. For instance, in mice almost all serum cholesterol resides in HDL, whereas in humans a significant portion of the serum cholesterol can be recovered from the VLDL and LDL. However, a TNF-induced increase in triglyceride levels was also observed in humans, which was paralleled by an increased rather than decreased lipolysis (497). The increased LPS- and LTA-induced triglyceride levels, along with the evidence that LPS and LTA are neutralized by lipoproteins, led to the hypothesis that these metabolic changes may be protective during bacterial infection $(189,293,313)$. To test this hypothesis, rats were treated with estradiol or 4-aminopyrolo-(3,4-D)-pyrimide to induce hypolipidemia, after which they were challenged with LPS. The TNF- $\alpha$ levels and mortality were significantly increased in the hypolipidemic animals (120). However, these animals could be rescued by the injection of lipoproteins prior to the challenge with LPS, confirming that hypolipidemic animals are more sensitive to LPS. Fraunberger et al. collected serum from sep- 
TABLE 6. Effects of inflammation and inflammatory mediators on lipid metabolism

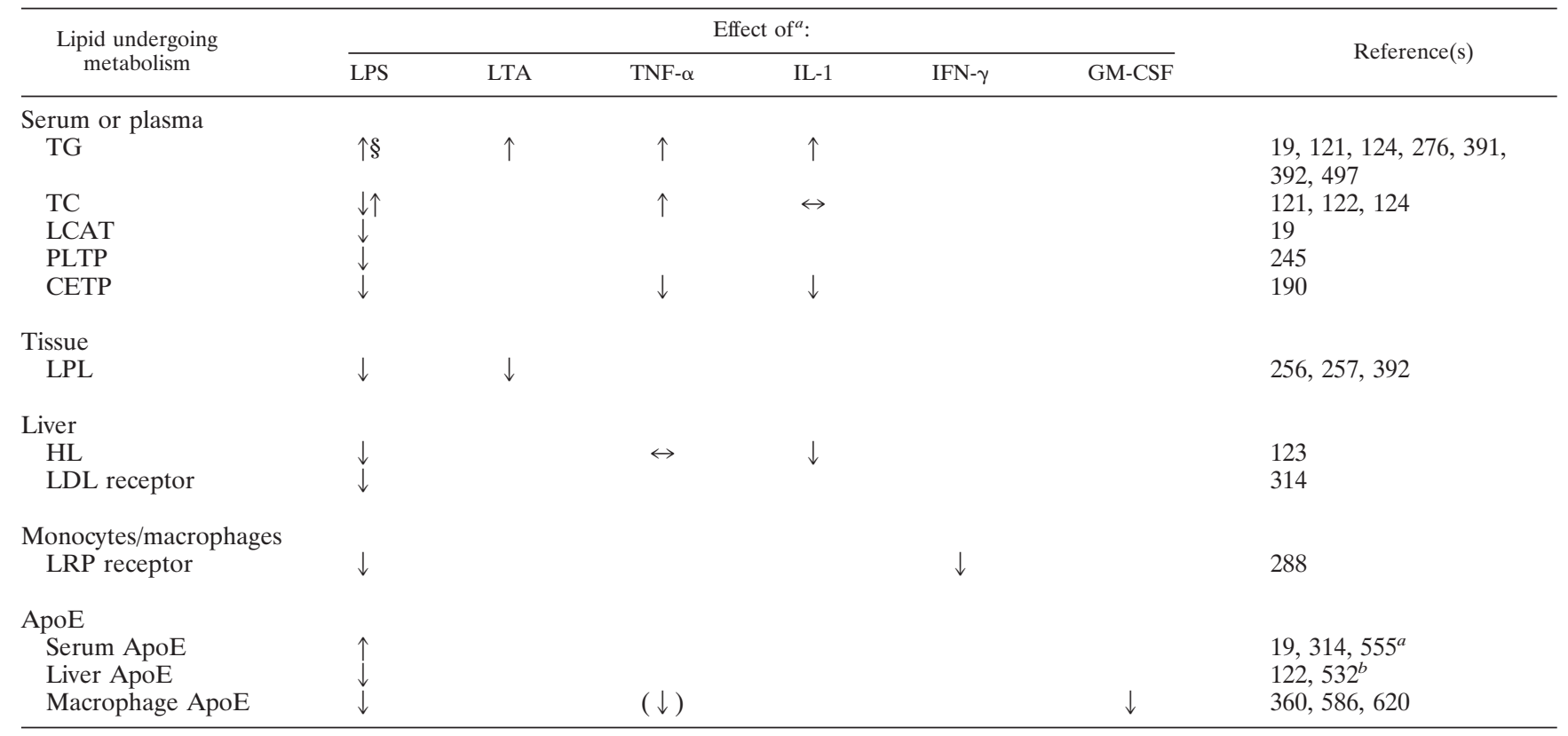

${ }^{a} \uparrow$, increase; $\downarrow$, decrease; $\leftrightarrow$, no change; $\downarrow \uparrow$, increased as well as decreased levels were observed.

${ }^{b}$ E. S. van Amersfoort et al., unpublished results.

tic patients and measured lipoprotein and apolipoprotein contents. In the septic patients, there was a marked increase in triglyceride levels, whereas cholesterol, ApoB and ApoA-I levels were reduced. They also observed an inverse relationship between serum cholesterol and TNF- $\alpha$ levels. A similar inverse relationship could be established between mortality and serum cholesterol levels (141-143). However, they did not show data on the serum triglyceride levels in this group of patients, which precludes a final conclusion about whether cholesterol or triglyceride levels may be protective in septic shock.

We have shown that serum ApoE levels are increased in mice which were injected with LPS, LTA, or live bacteria (555; van Amersfoort et al., unpublished). Along with the finding that ApoE is able to bind LPS and LTA, this also indicates that ApoE may be protective against LPS and LTA (449; van Amersfoort et al., unpublished). Fraunberger et al. observed an increase in HDL- and LDL-associated ApoE levels in human serum, whereas an increase in the HDL-associated ApoE level in LPS-treated African green monkeys was observed by Auerbach and Parks $(19,141)$. In contrast, decreased amounts of ApoE were detected in VLDL and LDL from septic rats (293). Administration of LPS to Syrian hamsters caused a reduction in liver ApoE mRNA levels but also a decreased release of ApoE and ApoB by the perfused rat liver $(122,532)$. In LPS-treated Syrian hamsters, the levels of ApoE mRNA were also reduced extrahepatically (191). LPS also caused a decrease in the release of ApoE by macrophages (Table 6) (294).

\section{CLINICAL AND EXPERIMENTAL SEPSIS THERAPIES}

Due to the complexity of immunologic defense and sepsis, the development of pharmacologic interventions is difficult (1, 218). One approach would be to prevent infection in patients at high risk. However, timely treatment to prevent sepsis or septic shock is often not possible, or the prevention of infection is simply insufficient. The standard treatment of bacterial sepsis often consists of administration of fluid and vasopressors to restore blood pressure and organ blood flow, oxygenation, and administration of antibiotics $(65,442,589)$. Although eradication of the microbial organism and treatment of the pathophysiological changes are essential, alternative approaches actively suppressing the deleterious effects of inflammation while retaining the antimicrobial defense are needed. In this section, some approaches to the treatment of sepsis and septic shock are briefly described.

The first alternative approach to treatment of sepsis was through antibody preparations to LPS. Three anti-lipid A IgM preparations were used, HA-1A and E5 and a polyclonal antiserum against the LPS core of E. coli J5. The human antiE. coli J5 (Rc-LPS) antiserum was first used to treat a small group of patients with septic shock. This cross-reactive antiserum barely significantly improved the overall prognosis in septic shock, but it was not possible to determine whether the antibodies or other compounds (e.g., inflammatory mediators) from the donor conferred protection (618). E5 decreased mortality in a first trial but provided no protection in successive trials $(8,174)$. HA-1A (Centoxin), was protective in one trial but had no effect in a second and tended to increase mortality in a subgroup of patients in a third trial $(31,69,548)$. Very little is known about the mechanism of protection of these antibodies. Although it was expected that the HA-1A antibody recognized lipid A specifically, it was later discovered that it bound rather nonspecifically to hydrophobic substances (31). Other attempts to treat patients with an anti-LPS antibody have also failed (218). As listed in Table 7 a substantial number of patients have been treated with the various preparations, but no overall benefit was observed. 
TABLE 7. Randomized controlled trials of immunotherapy in sepsis and septic shock ${ }^{a}$

\begin{tabular}{lcccc}
\hline \multirow{2}{*}{ Type of trial } & $\begin{array}{c}\text { No. of } \\
\text { trials }\end{array}$ & $\begin{array}{c}\text { Total no. of } \\
\text { patients }\end{array}$ & \multicolumn{2}{c}{$\begin{array}{c}\text { Mortality (\%) in } \\
\text { patients receiving: }\end{array}$} \\
\cline { 4 - 5 } & & & Placebo & Therapy \\
\hline Anti-endotoxin & 4 & 2,010 & 35 & 35 \\
Anti-IL-1R & 3 & 1,898 & 35 & 31 \\
Anti-bradykinin & 2 & 755 & 36 & 39 \\
Anti-PAF & 2 & 870 & 50 & 45 \\
Anti-TNF & 8 & 4,132 & 41 & 40 \\
Soluble TNF-R & 2 & 688 & 38 & 40 \\
NSAIDS & 3 & 514 & 40 & 37 \\
Steroids & 9 & 1,267 & 35 & 39 \\
Activated protein C & 1 & 1,690 & 31 & 25 \\
& & & & \\
All studies & 33 & 13,824 & 38 & 37 \\
\hline
\end{tabular}

${ }^{a}$ Adapted from reference 17 .

The recombinant 23-kDa N-terminal part of BPI, which is a powerful LPS-neutralizing agent, has also been used to treat septic patients. Although the initial results of a small trial in children with meningococcal sepsis were promising, a larger trial showed no real benefit $(167,309)$. In addition to the disappointing results of these trials, the use of therapeutics effective only against gram-negative organisms may not be desirable due to the delay caused by the time-consuming identification of the pathogenic organism.

Both in vitro studies with whole blood from septic patients and in vivo studies of healthy volunteers challenged with LPS indicate that treatment with recombinant HDL could be effective in combating septic shock. However, no data are yet available from clinical trials with recombinant $\operatorname{HDL}(171,408,409)$.

\section{Immunosuppression and Neutralization of Proinflammatory Cytokines}

Although general immunosuppression seems to be an obvious choice in the treatment of sepsis, the overall mortality increased (70). Similarly, nonsteroidal anti-inflammatory drugs that suppress the COX enzymes were also proven ineffective. Since TNF- $\alpha$ is a key mediator in the pathogenesis of sepsis, a recombinant humanized murine anti-TNF antibody preparation (Remicade or infliximab) and a TNF-R:Fc fusion protein (Enbrel, or etanercept) have been tested for the treatment of sepsis $(64,134)$. In clinical trials these preparations proved ineffective. Paradoxically, these TNF antagonists are very effective against Crohn's disease (inflammatory bowel disease) and rheumatoid arthritis, while they are contraindicated for infection and sepsis (113-115). Another important cytokine in inflammation and sepsis is IL-1. A recombinant IL-1 receptor antagonist has been tested in two large phase III trials but was not effective $(404,531)$. In healthy human volunteers, LPS tolerance could be induced by the infusion of monophosphoryl lipid A, but no clinical trials with septic patients have been performed (18). Interestingly, cross-tolerance to gram-positive infection could be induced in mice, indicating that this therapy might be effective in gram-negative and gram-positive sepsis (16).

The use of corticosteroids has been a subject of debate for many years. Corticosteroids are known to regulate a number of immune responses. They inhibit a number of inflammatory processes, such as leukocyte infiltration and cytokine production, and have a positive effect on cardiac output by a blockade of NO synthesis $(48,371)$. Based on these effects, patients have been treated in two large clinical trials using corticoids in the early phase of sepsis (326). The results of these trials indicated eventually that there were no beneficial effects of corticoids in the early phase of sepsis. More recently, it was observed that patients with a so-called adrenocortical insufficiency may have a poor prognosis $(45,70,305,492)$. Based on this hypothesis, trials were started in which patients were treated with a lower dose of corticosteroids (300 mg of hydrocortisone per day) for a number of days at a later stage in sepsis. The outcome of this lower dose of steroids seems to be more promising than the higher dose of steroids in the early phase of sepsis $(45,70,305$, 492).

The latest success in the treatment of sepsis in adults was the PROWESS study (Human Activated PROtein C Worldwide Evaluation in Severe Sepsis) (38). In this large double-blind study, the effect of activated protein $\mathrm{C}$ was studied. After the treatment of 1,520 patients, the study was abrogated because of the significant survival advantage in the actively treated group (24.7\% mortality versus $30.8 \%$ for placebo $[P=0.005])$. The mode of action of activated protein $\mathrm{C}$ is most probably based on its ability to inhibit both thrombosis (lower levels of Ddimer) and inflammation (as seen in a reduced level of IL-6), whereas fibrinolysis is promoted. However, more studies are needed before activated protein $\mathrm{C}$ is widely introduced as a therapeutic in the treatment. Although the blocking or modulation of a number of other targets, including complement and coagulation factors, neutrophil adherence, and NO release, are promising in animals, it remains to be determined whether these therapeutic approaches will be effective in humans (1, 218, 547).

\section{CONCLUDING REMARKS}

Despite the extensive array of protective mechanisms employed by bacteria, in mammals an innate, sensitive system to detect and eradicate bacteria has evolved. The immune system is a double-edged sword: besides its ability to effectively detect bacteria and mount an immune response to eradicate them, it may also cause serious damage to the body, even leading to death. The rise and fall of an immune response is regulated by a complex, extensive system of pro- and anti-inflammatory receptors, cytokines, and other serum factors affecting the bacteria directly or modulating the cellular response to the bacteria. It is difficult to unequivocally attribute a fully pro- or anti-inflammatory role to inflammatory mediators and receptors. The experiments with TNF knockout mice and TNF receptor knockout mice, for instance, have shown that these mice exhibit a drastically reduced sensitivity to LPS but succumb to small amounts of live bacteria or yeast $(343,422)$.

In human patients with sepsis, several putative therapies have aimed at the neutralization of the proinflammatory cytokines TNF and IL-1. These therapies have proven ineffective or even counterproductive in some cases, leading to unchanged or increased mortality in the drug-treated patient groups (64, 134). This shows that treatment of sepsis or septic shock may not simply be a matter of administrating anti-inflammatory 
agents or neutralizing their proinflammatory counterparts. Such therapeutic interventions may cause a shifted proinflammatory and anti-inflammatory balance, thus compromising the endogenous regulatory processes controlling the inflammatory cascade. Therapy of sepsis and septic shock will therefore have to simultaneously aim at maintaining homeostasis (part of the mechanism of action of the newly approved recombinant human activated protein $\mathrm{C}$ ) and at eradication of the bacteria. Instead of combating the detrimental immune response during sepsis, an attempt should be made to restore the balance between the pro- and anti-inflammatory responses.

\section{REFERENCES}

1. Abraham, E. 1999. Why immunomodulatory therapies have not worked in sepsis. Intensive Care Med. 25:556-566.

2. Acton, S., A. Rigotti, K. T. Landschulz, S. Xu, H. H. Hobbs, and M. Krieger. 1996. Identification of scavenger receptor SR-BI as a high density lipoprotein receptor. Science 271:518-520.

3. Agellon, L. B., E. M. Quinet, T. G. Gillette, D. T. Drayna, M. L. Brown, and A. R. Tall. 1990. Organization of the human cholesteryl ester transfer protein gene. Biochemistry 29:1372-1376.

4. Akagawa, K. S., and T. Tokunaga. 1985. Lack of binding of bacterial lipopolysaccharide to mouse lung macrophages and restoration of binding by gamma-interferon. J. Exp. Med. 162:1444-1459.

5. Akira, S. 2000. Toll-like receptors: lessons from knockout mice. Biochem. Soc. Trans. 28:551-556

6. Alexopoulou, L., A. C. Holt, R. Medzhitov, and R. A. Flavell. 2001. Recognition of double-stranded RNA and activation of NF-kB by Toll-like receptor 3. Nature 413:732-738.

7. Ammons, W. S., F. R. Kohn, and A. H. C. Kung. 1994. Protective effects of an N-terminal fragment of bactericidal/permeability-increasing protein in rodent models of Gram-negative sepsis: role of bactericidal properties. J. Infect. Dis. 170:1473-1482.

8. Angus, D. C., M. C. Birmingham, R. A. Balk, P. J. Scannon, D. Collins, J. A. Kruse, D. R. Graham, H. V. Dedhia, S. Homann, N. Maclntyre, and E5 Study Investigators. 2000. E5 murine monoclonal antiendotoxin antibody in gram-negative sepsis: a randomized controlled trial. JAMA 283:17231730 .

9. Antal-Szalmas, P., J. A. G. Van Strijp, A. J. L. Weersink, J. Verhoef, and K. P. M. Van Kessel. 1997. Quantitation of surface CD14 on human monocytes and neutrophils. J. Leukoc. Biol. 61:721-728.

10. Appelmelk, B. J., Y. Q. An, M. Geerts, B. G. Thijs, H. A. De Boer, D. M MacLaren, J. De Graaff, and J. H. Nuijens. 1994. Lactoferrin is a lipid A-binding protein. Infect. Immun. 62:2628-2632.

11. Arditi, M., J. Zhou, S. H. Huang, P. M. Luckett, M. N. Marra, and K. S. Kim. 1994. Bactericidal/permeability-increasing protein protects vascular endothelial cells from lipopolysaccharide-induced activation and injury. Infect. Immun. 62:3930-3936.

12. Armbrust, T., and G. Ramadori. 1996. Functional characterization of two different Kupffer cell populations of normal rat liver. J. Hepatol. 25:518528.

13. Asari, Y., M. Majima, K. Sugimoto, M. Katori, and T. Ohwada. 1996 Release site of TNF $\alpha$ after intravenous and intraperitoneal injection of LPS from Escherichia coli in rats. Shock 5:208-212.

14. Asea, A., M. Rehli, E. Kabingu, J. A. Boch, O. Bare, P. E. Auron, M. A Stevenson, and S. K. Calderwood. 2002. Novel signal transduction pathway utilized by extracellular HSP70. Role of Toll-like receptor (TLR) 2 and TLR4. J. Biol. Chem. 277:15028-15034

15. Ashkenas, J., M. Penman, E. Vasile, S. Acton, M. Freeman, and M. Krieger 1993. Structures and high and low affinity ligand binding properties of murine type I and type II macrophage scavenger receptors. J. Lipid Res. 34:983-1000

16. Astiz, M. E., A. Galera, D. C. Saha, C. Carpati, and E. C. Rackow. 1994 Monophosphoryl lipid A protects against gram-positive sepsis and tumor necrosis factor. Shock 2:271-274

17. Astiz, M. E., and E. C. Rackow. 1998. Septic shock. Lancet 351:1501-1505.

18. Astiz, M. E., E. C. Rackow, J. G. Still, S. T. Howell, A. Cato, K. B. Von Eschen, J. T. Ulrich, J. A. Rudbach, G. McMahon, and R. Vargas. 1995 Pretreatment of normal humans with monophosphoryl lipid A induces tolerance to endotoxin: a prospective, double-blind, randomized, controlled trial. Crit. Care Med. 23:9-17.

19. Auerbach, B. J., and J. S. Parks. 1989. Lipoprotein abnormalities associated with lipopolysaccharide-induced lecithin: cholesterol acyltransferase and lipase deficiency. J. Biol. Chem. 264:10264-10270.

20. Avila, E. M., G. Holdsworth, N. Sasaki, R. L. Jackson, and J. A. Harmony. 1982. Apoprotein E suppresses phytohemagglutinin-activated phospholipid turnover in peripheral blood mononuclear cells. J. Biol. Chem. 257:59005909
21. Aybay, C., and T. Imir. 1998. Comparison of the effects of Salmonella minnesota Re595 lipopolysaccharide, lipid A and monophosphoryl lipid A on nitric oxide, TNF- $\alpha$, and IL-6 induction from RAW 264.7 macrophages. FEMS Immunol. Med. Microbiol. 22:263-273.

22. Bainbridge, B. W., and R. P. Darveau. 2001. Porphyromonas gingivalis lipopolysaccharide: an unusual pattern recognition receptor ligand for the innate host defense system. Acta Odontol. Scand. 59:131-138.

23. Bals, R., X. Wang, M. Zasloff, and J. M. Wilson. 1998. The peptide antibiotic LL-37/hCAP-18 is expressed in epithelia of the human lung where it has broad antimicrobial activity at the airway surface. Proc. Natl. Acad. Sci. USA 95:9541-9546.

24. Bals, R., D. J. Weiner, A. D. Moscioni, R. L. Meegalla, and J. M. Wilson. 1999. Augmentation of innate host defense by expression of a cathelicidin antimicrobial peptide. Infect. Immun. 67:6084-6089.

25. Bannan, J., K. Visvanathan, and J. B. Zabriskie. 1999. Structure and function of streptococcal and staphylococcal superantigens in septic shock. Infect. Dis. Clin. North Am. 13:387-396, ix.

26. Basu, S. K., M. S. Brown, Y. K. Ho, R. J. Havel, and J. L. Goldstein. 1981 Mouse macrophages synthesize and secrete a protein resembling apolipoprotein E. Proc. Natl. Acad. Sci. USA 78:7545-7549.

27. Bates, D. W., K. E. Pruess, and T. H. Lee. 1995. How bad are bacteremia and sepsis? Outcomes in a cohort with suspected bacteremia. Arch. Intern. Med. 155:593-598.

28. Bauer, R. J., K. Der, N. Ottah-Ihejeto, J. Barrientos, and A. H. Kung. 1997 The role of liver and kidney on the pharmacokinetics of a recombinan amino terminal fragment of bactericidal/permeability-increasing protein in rats. Pharm. Res. 14:224-229.

29. Bauer, R. J., M. L. White, N. Wedel, B. J. Nelson, N. Friedmann, A. Cohen, W. N. M. Hustinx, and A. H. C. Kung. 1996. A phase I safety and pharmacokinetic study of a recombinant amino terminal fragment of bactericidal/permeability-increasing protein in healthy male volunteers. Shock 5:91-96.

30. Baumberger, C., R. J. Ulevitch, and J. M. Dayer. 1991. Modulation of endotoxic activity of lipopolysaccharide by high-density lipoprotein. Pathobiology 59:378-383

31. Baumgartner, J. D. 1990. Monoclonal anti-endotoxin antibodies for the treatment of Gram-negative bacteremia and septic shock. Eur. J. Clin. Microbiol. Infect. Dis. 9:711-716.

32. Bautista, A. P., A. Schuler, Z. Spolarics, and J. J. Spitzer. 1991. Tumor necrosis factor- $\alpha$ stimulates superoxide anion generation by perfused rat liver and Kupffer cells. Am. J. Physiol. 261:G891-G895.

33. Bautista, A. P., N. Skrepnik, M. R. Niesman, and G. J. Bagby. 1994 Elimination of macrophages by liposome-encapsulated dichloromethylene diphosphonate suppresses the endotoxin-induced priming of Kupffer cells J. Leukoc. Biol. 55:321-327.

34. Baveye, S., E. Elass, D. G. Fernig, C. Blanquart, J. Mazurier, and D. Legrand. 2000. Human lactoferrin interacts with soluble CD14 and inhibits expression of endothelial adhesion molecules, E-selectin and ICAM-1, induced by the CD14-lipopolysaccharide complex. Infect. Immun. 68:65196525 .

35. Baveye, S., E. Elass, J. Mazurier, G. Spik, and D. Legrand. 1999. Lactoferrin: a multifunctional glycoprotein involved in the modulation of the inflammatory process. Clin. Chem. Lab. Med. 37:281-286.

36. Bazil, V., V. Horejsi, M. Baudys, H. Kristofova, J. L. Strominger, W. Kostka, and I. Hilgert. 1986. Biochemical characterization of a soluble form of the 53-kDa monocyte surface antigen. Eur. J. Immunol. 16:1583-1589.

37. Berger, D., and H. G. Beger. 1987. Evidence for endotoxin binding capacity of human Gc-globulin and transferrin. Clin. Chim. Acta 163:289-299.

38. Bernard, G. R., J. L. Vincent, P. F. Laterre, S. P. LaRosa, J. F. Dhainaut, A. Lopez-Rodriguez, J. S. Steingrub, G. E. Garber, J. D. Helterbrand, E. W. Ely, and C. J. Fisher, Jr. 2001. Efficacy and safety of recombinant human activated protein C for severe sepsis. N. Engl. J. Med. 344:699-709.

39. Beutler, B., I. W. Milsark, and A. C. Cerami. 1985. Passive immunization against cachectin/tumor necrosis factor protects mice from lethal effect of endotoxin. Science 229:869-871.

40. Bhakdi, S., T. Klonisch, P. Nuber, and W. Fischer. 1991. Stimulation of monokine production by lipoteichoic acids. Infect. Immun. 59:4614-4620.

41. Biozzi, G., J. G. Howard, B. N. Halpern, C. Stiffel, and D. Mouton. 1960 The kinetics of blood clearance of isotopically labelled Salmonella enteritidis by the reticulo-endothelial system in mice. Immunology 3:74-89.

42. Bone, R. C. 1991. The pathogenesis of sepsis. Ann. Intern. Med. 115:457469.

43. Bone, R. C. 1993. Why new definitions of sepsis are needed. Am. J. Med. 95:348-350.

44. Bone, R. C. 1994. Gram-positive organisms and sepsis. Arch. Intern. Med 154:26-34.

45. Bone, R. C., C. J. Fisher, Jr., T. P. Clemmer, G. J. Slotman, C. A. Metz, and R. A. Balk. 1987. A controlled clinical trial of high-dose methylprednisolone in the treatment of severe sepsis and septic shock. N. Engl. J. Med. 317: 653-658.

46. Borron, P., J. C. McIntosh, T. R. Korfhagen, J. A. Whitsett, J. Taylor, and J. R. Wright. 2000. Surfactant-associated protein A inhibits LPS-induced 
cytokine and nitric oxide production in vivo. Am. J. Physiol. Lung Cell Mol. Physiol. 278:L840-L847.

47. Bosisio, D., N. Polentarutti, M. Sironi, S. Bernasconi, K. Miyake, G. R Webb, M. U. Martin, A. Mantovani, and M. Muzio. 2002. Stimulation of toll-like receptor 4 expression in human mononuclear phagocytes by inter feron- $\gamma$ : a molecular basis for priming and synergism with bacterial lipopolysaccharide. Blood 99:3427-3431.

48. Boumpas, D. T., G. P. Chrousos, R. L. Wilder, T. R. Cupps, and J. E. Balow. 1993. Glucocorticoid therapy for immune-mediated diseases: basic and clinical correlates. Ann. Intern. Med. 119:1198-1208.

49. Bowie, A., and L. A. O'Neill. 2000. The interleukin-1 receptor/Toll-like receptor superfamily: signal generators for pro-inflammatory interleukins and microbial products. J. Leukoc. Biol. 67:508-514.

50. Brackett, D. J., M. R. Lerner, M. A. Lacquement, R. He, and H. A. Pereira. 1997. A synthetic lipopolysaccharide-binding peptide based on the neutrophil-derived protein CAP37 prevents endotoxin-induced responses in conscious rats. Infect. Immun. 65:2803-2811.

51. Brandenburg, K., M. H. J. Koch, and U. Seydel. 1992. Phase diagram of deep rough mutant lipopolysaccharide from Salmonella minnesota R595. J. Struct. Biol. 108:93-106.

52. Brandenburg, K., U. Seydel, A. B. Schromm, H. Loppnow, M. H. J. Koch, and E. T. Rietschel. 1996. Conformation of lipid A, the endotoxic center of bacterial lipopolysaccharide. J. Endotoxin Res. 3:173-178.

53. Brightbill, H. D., D. H. Libraty, S. R. Krutzik, R. B. Yang, J. T. Belisle, J. R. Bleharski, M. Maitland, M. V. Norgard, S. E. Plevy, S. T. Smale, P. J. Brennan, B. R. Bloom, P. J. Godowski, and R.L. Modlin. 1999. Host defense mechanisms triggered by microbial lipoproteins through toll-like receptors. Science 285:732-736.

54. Brito, B. E., E. L. Romano, and C. Grunfeld. 1995. Increased lipopolysaccharide-induced tumour necrosis factor levels and death in hypercholesterolaemic rabbits. Clin. Exp. Immunol. 101:357-361.

55. Bulut, Y., E. Faure, L. Thomas, H. Karahashi, K. S. Michelsen, O. Equils, S. G. Morrison, R. P. Morrison, and M. Arditi. 2002. Chlamydial heat shock protein 60 activates macrophages and endothelial cells through Toll-like receptor 4 and MD2 in a MyD88-dependent pathway. J. Immunol. 168: $1435-1440$

56. Caccavo, D., A. Afeltra, S. Pece, G. Giuliani, M. Freudenberg, C. Galanos, and E. Jirillo. 1999. Lactoferrin-lipid A-lipopolysaccharide interaction: inhibition by anti-human lactoferrin monoclonal antibody AGM 10.14. Infect. Immun. 67:4668-4672.

57. Calabresi, L., G. Franceschini, C. R. Sirtori, A. De Palma, M. Saresella, P. Ferrante, and D. Taramelli. 1997. Inhibition of VCAM-1 expression in endothelial cells by reconstituted high density lipoproteins. Biochem. Biophys. Res. Commun. 238:61-65.

58. Cameron, S. B., M. C. Nawijn, W. W. Kum, H. F. Savelkoul, and A. W. Chow. 2001. Regulation of helper T cell responses to staphylococcal superantigens. Eur. Cytokine Netw. 12:210-222.

59. Cario, E., I. M. Rosenberg, S. L. Brandwein, P. L. Beck, H. C. Reinecker, and D. K. Podolsky. 2000. Lipopolysaccharide activates distinct signaling pathways in intestinal epithelial cell lines expressing toll-like receptors J. Immunol. 164:966-972.

60. Casas, A. T., A. P. Hubsch, B. C. Rogers, and J. E. Doran. 1995. Reconstituted high-density lipoprotein reduces LPS-stimulated TNF $\alpha$. J. Surg. Res. 59:544-552.

61. Cavaillon, J. M., C. Fitting, N. Haeffner-Cavaillon, S. J. Kirsch, and H. S. Warren. 1990. Cytokine response by monocytes and macrophages to free and lipoprotein-bound lipopolysaccharide. Infect. Immun. 58:2375-2382.

62. Chatham, W. W., and W. D. Blackburn, Jr. 1993. Fixation of C3 to $\operatorname{IgC}$ attenuates neutrophil $\mathrm{HOCl}$ generation and collagenase activation. J. Immunol. 151:949-958.

63. Chuang, T. H., and R. J. Ulevitch. 2000. Cloning and characterization of a sub-family of human toll-like receptors: hTLR7, hTLR8 and hTLR9. Eur. Cytokine Netw. 11:372-378.

64. Clark, M. A., L. D. Plank, A. B. Connolly, S. J. Streat, A. A. Hill, R. Gupta, D. N. Monk, A. Shenkin, and G. L. Hill. 1998. Effect of a chimeric antibody to tumor necrosis factor- $\alpha$ on cytokine and physiologic responses in patients with severe sepsis-a randomized, clinical trial. Crit. Care Med. 26:1650 1659

65. Cohen, J., and M. P. Glauser. 1991. Septic shock: treatment. Lancet 338: 736-739.

66. Coley, J., M. Duckworth, and J. Baddiley. 1975. Extraction and purification of lipoteichoic acids from Gram-positive bacteria. Carbohydr. Res. 40:4152.

67. Corradin, S. B., D. Heumann, P. Gallay, J. Smith, J. Mauël, and M. P. Glauser. 1994. Bactericidal/permeability-increasing protein inhibits induction of macrophage nitric oxide production by lipopolysaccharide. J. Infect. Dis. 169:105-111.

68. Corradin, S. B., J. Mauël, P. Gallay, D. Heumann, R. J. Ulevitch, and P. S. Tobias. 1992. Enhancement of murine macrophage binding of and response to bacterial lipopolysaccharide (LPS) by LPS-binding protein. J. Leukoc. Biol. 52:363-368.

69. Costongs, L. G. P., P. Speelman, J. J. Van Lieshout, S. J. H. Van Deventer,
M. J. Lubbers, and H. G. Schipper. 1993. Immunotherapie met de antiendotoxine-antistof HA-1A (Centoxin) bij patiënten met het sepsissyndroom: matige resultaten na geprotocolleerde selectie van patiënten. Ned. Tijdschr. Geneeskd. 137:355-360.

70. Cronin, L., D. J. Cook, J. Carlet, D. K. Heyland, D. King, M. A. Lansang, and C. J. Fisher, Jr. 1995. Corticosteroid treatment for sepsis: a critical appraisal and meta- analysis of the literature. Crit. Care Med. 23:14301439.

71. Crosby, H. A., J. F. Bion, C. W. Penn, and T. S. J. Elliott. 1994. Antibioticinduced release of endotoxin from bacteria in vitro. J. Med. Microbiol. 40:23-30.

72. Cué, J. I., J. T. DiPiro, L. J. Brunner, J. E. Doran, M. E. Blankenship, A. R. Mansberger, and M. L. Hawkins. 1994. Reconstituted high density lipoprotein inhibits physiologic and tumor necrosis factor $\alpha$ responses to lipopolysaccharide in rabbits. Arch. Surg. 129:193-197.

73. Cui, W., D. C. Morrison, and R. Silverstein. 2000. Differential tumor necrosis factor $\alpha$ expression and release from peritoneal mouse macrophages in vitro in response to proliferating gram-positive versus gram-negative bacteria. Infect. Immun. 68:4422-4429.

74. Cunha, F. Q., J. Assreuy, D. W. Moss, D. Rees, L. M. C. Leal, S. Moncada, M. Carrier, C. A. O'Donnell, and F. Y. Liew. 1994. Differential induction of nitric oxide synthase in various organs of the mouse during endotoxaemia: role of TNF- $\alpha$ and IL-1 $\beta$. Immunology 81:211-215.

75. Curtiss, L. K., and W. A. Boisvert. 2000. Apolipoprotein E and atherosclerosis. Curr. Opin. Lipidol. 11:243-251.

76. Cuzzola, M., G. Mancuso, C. Beninati, C. Biondo, F. Genovese, F. Tomasello, T. H. Flo, T. Espevik, and G. Teti. 2000. $\beta_{2}$-Integrins are involved in cytokine responses to whole Gram-positive bacteria. J. Immunol. 164:58715876.

77. Dabbagh, K., M. E. Dahl, P. Stepick-Biek, and D. B. Lewis. 2002. Toll-like receptor 4 is required for optimal development of Th2 immune responses: role of dendritic cells. J. Immunol. 168:4524-4530.

78. Dankesreiter, S., A. Hoess, J. Schneider-Mergener, H. Wagner, and T. Miethke. 2000. Synthetic endotoxin-binding peptides block endotoxin-triggered TNF-alpha production by macrophages in vitro and in vivo and prevent endotoxin-mediated toxic shock. J. Immunol. 164:4804-4811.

79. da Silva, C. J., K. Soldau, U. Christen, P. S. Tobias, and R. J. Ulevitch. 2001. Lipopolysaccharide is in close proximity to each of the proteins in it membrane receptor complex. Transfer from CD14 to TLR4 and MD-2. J. Biol. Chem. 276:21129-21135.

80. Daugherty, A., J. A. Cornicelli, K. Welch, S. M. Sendobry, and D. L. Rateri. 1997. Scavenger receptors are present on rabbit aortic endothelial cells in vivo. Arterioscler. Thromb. Vasc. Biol. 17:2369-2375.

81. Deaciuc, I. V., G. J. Bagby, M. R. Niesman, N. Skrepnik, and J. J. Spitzer. 1994. Modulation of hepatic sinusoidal endothelial cell function by Kupffer cells: an example of intercellular communication in the liver. Hepatology 19:464-470

82. De Bleser, P. J., F. Braet, P. Lovisetti, K. Vanderkerken, B. Smedsrod, E Wisse, and A. Geerts. 1994. Cell biology of liver endothelial and Kupffer cells. Gut 35:1509-1516.

83. De Boer, J. P., A. A. Creasey, A. Chang, D. Roem, A. J. M. Eerenberg, C. E. Hack, and F. B. Taylor, Jr. 1993. Activation of the complement system in baboons challenged with live Escherichia coli: correlation with mortality and evidence for a biphasic activation pattern. Infect. Immun. 61:4293-4301.

84. de Bont, N., M. G. Netea, P. N. Demacker, I. Verschueren, B. J. Kullberg, K. W. van Dijk, J. W. van der Meer, and A. F. Stalenhoef. 1999. Apolipoprotein E knock-out mice are highly susceptible to endotoxemia and Klebsiella pneumoniae infection. J. Lipid Res. 40:680-685.

85. Decker, K. 1990. Biologically active products of stimulated liver macrophages (Kupffer cells). Eur. J. Biochem. 192:245-261.

86. de Haas, C. J., M. J. Poppelier, K. P. Van Kessel, and J. A. Van Strijp. 2000 Serum amyloid $\mathrm{P}$ component prevents high-density lipoprotein-mediated neutralization of lipopolysaccharide. Infect. Immun. 68:4954-4960.

87. de Haas, C. J., M. E. Van Der Tol, K. P. Van Kessel, J. Verhoef, and J. A. Van Strijp. 1998. A synthetic lipopolysaccharide-binding peptide based on amino acids $27-39$ of serum amyloid $P$ component inhibits lipopolysaccharide-induced responses in human blood. J. Immunol. 161:3607-3615.

88. de Haas, C. J., E. M. van Leeuwen, T. van Bommel, J. Verhoef, K. P. Van Kessel, and J. A. Van Strijp. 2000. Serum amyloid P component bound to gram-negative bacteria prevents lipopolysaccharide-mediated classical pathway complement activation. Infect. Immun. 68:1753-1759.

89. De Kimpe, S. J., M. L. Hunter, C. E. Bryant, C. Thiemermann, and J. R. Vane. 1995. Delayed circulatory failure due to the induction of nitric oxide synthase by lipoteichoic acid from Staphylococcus aureus in anaesthetized rats. Br. J. Pharmacol. 114:1317-1323.

90. De Kimpe, S. J., M. Kengatharan, C. Thiemermann, and J. R. Vane. 1995 The cell wall components peptidoglycan and lipoteichoic acid from Staphylococcus aureus act in synergy to cause shock and multiple organ failure. Proc. Natl. Acad. Sci. USA 92:10359-10363.

91. Dentener, M. A., E. J. U. Von Asmuth, G. J. M. Francot, M. N. Marra, and W. A. Buurman. 1993. Antagonistic effects of lipopolysaccharide binding protein and bactericidal/permeability-increasing protein on lipopolysaccha- 
ride-induced cytokine release by mononuclear phagocytes: competition for binding to lipopolysaccharide. J. Immunol. 151:4258-4265.

92. Desmet, V. J. 1994. Introduction. Organizational principles, p. 3-14. In I. M Arias, J. L. Boyer, N. Fausto, W. B. Jakoby, D. A. Schachter, and D. A Shafritz (eds.), The liver: biology and pathobiology. Raven Press, New York, N.Y.

93. Detmers, P. A., N. Thieblemont, T. Vasselon, R. Pironkova, D. S. Miller, and S. D. Wright. 1996. Potential role of membrane internalization and vesicle fusion in adhesion of neutrophils in response to lipopolysaccharide and TNF. J. Immunol. 157:5589-5596.

94. Díaz-Laviada, I., J. Ainaga, M. T. Portolés, J. L. Carrascosa, A. M. Muncio, and R. Pagani. 1991. Binding studies and localization of Escherichia coli lipopolysaccharide in cultured hepatocytes by an immunocolloidal-gold technique. Histochem. J. 23:221-228.

95. Dmitriev, B. A., S. Ehlers, and E. T. Rietschel. 1999. Layered murein revisited: a fundamentally new concept of bacterial cell wall structure, biogenesis and function. Med. Microbiol. Immunol. (Berlin) 187:173-181.

96. Doi, T., K. Higashino, Y. Kurihara, Y. Wada, T. Miyazaki, H. Nakamura S. Uesugi, T. Imanishi, Y. Kawabe, H. Itakura, Y. Yazaki, A. Matsumoto, and T. Kodama. 1993. Charged collagen structure mediates the recognition of negatively charged macromolecules by macrophage scavenger receptors. J. Biol. Chem. 268:2126-2133.

97. Dunne, D. W., D. Resnick, J. W. Greenberg, M. Krieger, and K. A. Joiner. 1994. The type I macrophage scavenger receptor binds to Gram-positive bacteria and recognizes lipoteichoic acid. Proc. Natl. Acad. Sci. USA 91: 1863-1867.

98. Durieux, J. J., N. Vita, O. Popescu, F. Guette, J. Calzada-Wack, R. Munker, R. E. Schmidt, J. Lupker, P. Ferrara, H. W. L. Ziegler-Heitbrock, and M. O. Labeta. 1994. The two soluble forms of the lipopolysaccharide receptor, CD14: characterization and release by normal human monocytes. Eur. J. Immunol. 24:2006-2012.

99. Dziarski, R. 1991. Peptidoglycan and lipopolysaccharide bind to the same binding site on lymphocytes. J. Biol. Chem. 266:4719-4725.

100. Dziarski, R., Y. P. Jin, and D. Gupta. 1996. Differential activation of extracellular signal-regulated kinase (ERK) 1, ERK2, p38, and c-Jun $\mathrm{NH}_{2}$ terminal kinase mitogen-activated protein kinases by bacterial peptidoglycan. J. Infect. Dis. 174:777-785.

101. Eggesbo, J. B., I. Hjermann, A. T. Hostmark, and P. Kierulf. 1996. LPS induced release of IL-1 $\beta$, II-6, IL- 8 and TNF- $\alpha$ in EDTA or heparin anticoagulated whole blood from persons with high or low levels of serum HDL. Cytokine 8:152-160.

102. Eggesbo, J. B., T. Lyberg, T. Aspelin, I. Hjermann, and P. Kierulf. 1996 Different binding of ${ }^{125}$ I-LPS to plasma proteins from persons with high or low HDL. Scand. J. Clin. Lab. Investig. 56:533-543.

103. Eichbaum, E. B., H. W. Harris, J. P. Kane, and J. H. Rapp. 1991. Chylomicrons can inhibit endotoxin activity in vitro. J. Surg. Res. 51:413-416.

104. Elass-Rochard, E., D. Legrand, V. Salmon, A. Roseanu, M. Trif, P. S. Tobias, J. Mazurier, and G. Spik. 1998. Lactoferrin inhibits the endotoxin interaction with CD14 by competition with the lipopolysaccharide-binding protein. Infect. Immun. 66:486-491.

105. Elass-Rochard, E., A. Roseanu, D. Legrand, M. Trif, V. Salmon, C. Motas, J. Montreuil, and G. Spik. 1995. Lactoferrin-lipopolysaccharide interaction: involvement of the 28-34 loop region of human lactoferrin in the high-affinity binding to Escherichia coli O55B5 lipopolysaccharide. Biochem. J. 312:839-845.

106. Ellison, R. T., III, and T. J. Giehl. 1991. Killing of gram-negative bacteria by lactoferrin and lysozyme. J. Clin. Investis. 88:1080-1091.

107. Elomaa, O., M. Kangas, C. Sahlberg, J. Tuukkanen, R. Sormunen, A Liakka, I. Thesleff, G. Kraal, and K. Tryggvason. 1995. Cloning of a novel bacteria-binding receptor structurally related to scavenger receptors and expressed in a subset of macrophages. Cell 80:603-609.

108. Elomaa, O., M. Sankala, T. Pikkarainen, U. Bergmann, A. Tuuttila, A Raatikainen-Ahokas, H. Sariola, and K. Tryggvason. 1998. Structure of the human macrophage MARCO receptor and characterization of its bacteriabinding region. J. Biol. Chem. 273:4530-4538.

109. Elsbach, P., and J. Weiss. 1993. Bacterial/permeability increasing protein and host defense against Gram-negative bacteria and endotoxin. Curr. Opin. Immunol. 5:103-107.

110. Elsbach, P., J. Weiss, R. C. Franson, S. Beckerdite-Quagliata, A. Schneider, and L. Harris. 1979. Separation and purification of a potent bactericidal/ permeability-increasing protein and a closely associated phospholipase A2 from rabbit polymorphonuclear leukocytes. J. Biol. Chem. 254:1100011009.

111. Elshourbagy, N. A., W. S. Liao, R. W. Mahley, and J. M. Taylor. 1985 Apolipoprotein E mRNA is abundant in the brain and adrenals, as well as in the liver, and is present in other peripheral tissues of rats and marmosets Proc. Natl. Acad. Sci. USA 82:203-207.

112. Emancipator, K., G. Csako, and R. J. Elin. 1992. In vitro inactivation of bacterial endotoxin by human lipoproteins and apolipoproteins. Infect. Immun. 60:596-601.

113. EMEA. 1999. Opinion of the committee for proprietary medicinal products on the granting of a marketing authorisation for etanercept. CPMP/2402/
1999-EN, EMEA/H/C/262, ANNEX 1. 18-11-1999. EMEA, London, England.

114. EMEA. 1999. Opinion of the committee for proprietary medicinal products on the granting of a marketing authorisation for infliximab. CPMP/1478/ 99-EN; EMEA/H/C/240, ANNEX 1. 20-5-1999. EMEA, London, England.

115. EMEA. 2000. EMEA public statement on infliximab (Remicade): reports of tuberculosis infections. EMEA/CPMP/4445/00. 20-12-2000. EMEA, London, England.

116. Espevik, T., M. Otterlei, G. Skjåk-Bræk, L. Ryan, S. D. Wright, and A. Sundan. 1993. The involvement of CD14 in stimulation of cytokine production by uronic acid polymers. Eur. J. Immunol. 23:255-261.

117. Evans, T. J., A. Carpenter, D. Moyes, R. Martin, and J. Cohen. 1995. Protective effects of a recombinant amino-terminal fragment of human bactericidal/permeability-increasing protein in an animal model of Gramnegative sepsis. J. Infect. Dis. 171:153-160.

118. Faure, E., O. Equils, P. A. Sieling, L. Thomas, F. X. Zhang, C. J. Kirschning, N. Polentarutti, M. Muzio, and M. Arditi. 2000. Bacterial lipopolysaccharide activates NF- $\mathrm{B}$ through toll-like receptor 4 (TLR-4) in cultured human dermal endothelial cells. Differential expression of TLR-4 and TLR-2 in endothelial cells. J. Biol. Chem. 275:11058-11063.

119. Fearns, C., V. Kravchenko, R. J. Ulevitch, and D. J. Loskutoff. 1995. Murine CD14 gene expression in vivo: extramyeloid synthesis and regulation by lipopolysaccharide. J. Exp. Med. 181:857-866.

120. Feingold, K. R., J. L. Funk, A. H. Moser, J. K. Shigenaga, J. H. Rapp, and C. Grunfeld. 1995. Role for circulating lipoproteins in protection from endotoxin toxicity. Infect. Immun. 63:2041-2046.

121. Feingold, K. R., and C. Grunfeld. 1987. Tumor necrosis factor- $\alpha$ stimulates hepatic lipogenesis in the rat in vivo. J. Clin. Investis. 80:184-190.

122. Feingold, K. R., I. Hardardottir, R. Memon, E. J. Krul, A. H. Moser, J. M. Taylor, and C. Grunfeld. 1993. Effect of endotoxin on cholesterol biosynthesis and distribution in serum lipoproteins in Syrian hamsters. J. Lipid Res. 34:2147-2158.

123. Feingold, K. R., R. A. Memon, A. H. Moser, J. K. Shigenaga, and C. Grunfeld. 1999. Endotoxin and interleukin-1 decrease hepatic lipase mRNA levels. Atherosclerosis 142:379-387.

124. Feingold, K. R., M. Soued, S. Adi, I. Staprans, R. Neese, J. Shigenaga, W. Doerrler, A. H. Moser, C. A. Dinarello, and C. Grunfeld. 1991. Effect of interleukin-1 on lipid metabilism in the rat: similarities to and differences from tumor necrosis factor. Arterioscler. Thromb. 11:495-500.

125. Feingold, K. R., I. Staprans, R. A. Memon, A. H. Moser, J. K. Shigenaga, W. Doerrler, C. A. Dinarello, and C. Grunfeld. 1992. Endotoxin rapidly induces changes in lipid metabolism that produce hypertriglyceridemia: low doses stimulate hepatic triglyceride production while high doses inhibit clearance. J. Lipid Res. 33:1765-1776.

126. Ferrero, E., and S. M. Goyert. 1988. Nucleotide sequence of the gene encoding the monocyte differentiation antigen, CD14. Nucleic Acids Res. 16:4173.

127. Ferrero, E., C. L. Hsieh, U. Francke, and S. M. Goyert. 1990. CD14 is a member of the family of the leucine-rich proteins and is encoded by a gene syntenic with multiple receptor genes. J. Immunol. 145:331-336.

128. Ferrero, E., D. Jiao, B. Z. Tsuberi, L. Tesio, G. Wei Rong, and A. Haziot. 1993. Transgenic mice expressing human CD14 are hypersensitive to lipopolysaccharide. Proc. Natl. Acad. Sci. USA 90:2380-2384.

129. Fey, G. H., G. M. Hocke, D. R. Wilson, J. A. Ripperger, T. S. C. Juan, M. Z Cui, and G. J. Darlington. 1994. Cytokines and the acute phase response of the liver, p. 113-143. In I. M. Arias, J. L. Boyer, N. Fausto, W. B. Jakoby, D. A. Schachter, and D. A. Shafritz (ed.), The liver: biology and pathobiology. Raven Press, New York, N.Y.

130. Fischer, W. 1993. Molecular analysis of lipid macroamphiphiles by hydrophobic interaction chromatography, exemplified with lipoteichoic acids Anal. Biochem. 208:49-56.

131. Fischer, W. 1994. Lipoteichoic acid and lipids in the membrane of Staphylococcus aureus. Med. Microbiol. Immunol. (Berlin) 183:61-76.

132. Fischer, W., and H. U. Koch. 1985. Alanyl lipoteichoic acid of Staphylococ cus aureus: functional and dynamic aspects. Biochem. Soc. Trans. 13:984 986.

133. Fischer, W., T. Mannsfeld, and G. Hagen. 1990. On the basic structure of poly(glycerophosphate) lipoteichoic acids. Biochem. Cell Biol. 68:33-43.

134. Fisher, C. J., J. M. Agosti, S. M. Opal, S. F. Lowry, R. A. Balk, J. C. Sadoff, E. Abraham, R. M. Schein, E. Benjamin, and The Soluble TNF Receptor Sepsis Study Group. 1996. Treatment of septic shock with the tumor necrosis factor receptor:Fc fusion protein. N. Engl. J. Med. 334:1697-1702.

135. Flegel, W. A., M. W. Baumstark, C. Weinstock, A. Berg, and H. Northoff. 1993. Prevention of endotoxin-induced monokine release by human lowand high-density lipoproteins and by apolipoprotein A-I. Infect. Immun. 61:5140-5146.

136. Flegel, W. A., A. Wölpl, D. Männel, and H. Northoff. 1989. Inhibition of endotoxin-induced activation of human monocytes by human lipoproteins. Infect. Immun. 57:2237-2245

137. Fox, E. S., P. Thomas, and S. A. Broitman. 1987. Comparative studies of endotoxin uptake by isolated rat Kupffer and peritoneal cells. Infect. Immun. 55:2962-2966. 
138. Fox, E. S., P. Thomas, and S. A. Broitman. 1988. Uptake and modification of ${ }^{125}$ I-lipopolysaccharide by isolated rat Kupffer cells. Hepatology 8:1550 1554.

139. Fox, E. S., P. Thomas, and S. A. Broitman. 1989. Clearance of gut-derived endotoxins by the liver. Release and modification of ${ }^{3} \mathrm{H},{ }^{14} \mathrm{C}$-lipopolysaccharide by isolated rat Kupffer cells. Gastroenterology 96:456-461.

140. Frank, M. M., and L. F. Fries. 1991. The role of complement in inflammation and phagocytosis. Immunol. Today 12:322-331.

141. Fraunberger, P., K. G. Parhofer, P. Cremer, A. Gerling, B. Siegele, A. K. Walli, and D. Seidel. 1997. Lipid and apolipoprotein composition of lipoproteins in hypocholesterolemia of sepsis. Arteriosclerosis 134:S349.

142. Fraunberger, P., G. Pilz, P. Cremer, K. Werdan, and A. K. Walli. 1998 Association of serum tumor necrosis factor levels with decrease of cholesterol during septic shock. Shock 10:359-363.

143. Fraunberger, P., S. Schaefer, K. Werdan, A. K. Walli, and D. Seidel. 1999 Reduction of circulating cholesterol and apolipoprotein levels during sepsis. Clin. Chem. Lab. Med. 37:357-362.

144. Freudenberg, M. A., T. C. Bog-Hansen, U. Back, and C. Galanos. 1980. Interaction of lipopolysaccharides with plasma high-density lipoprotein in rats. Infect. Immun. 28:373-380.

145. Freudenberg, M. A., N. Freudenberg, and C. Galanos. 1982. Time course of cellular distribution of endotoxin in liver, lungs and kidneys of rats. Br. J. Exp. Pathol. 63:56-65.

146. Freudenberg, M. A., and C. Galanos. 1990. Bacterial lipopolysaccharides: structure, metabolism and mechanisms of action. Int. Rev. Immunol. 6:207221.

147. Freudenberg, M. A., D. Keppler, and C. Galanos. 1986. Requirement for lipopolysaccharide-responsive macrophages in galactosamine-induced sensitization to endotoxin. Infect. Immun. 51:891-895.

148. Freudenberg, M. A., B. Kleine, and C. Galanos. 1984. The fate of lipopolysaccharide in rats: evidence for chemical alteration in the molecule. Rev. Infect. Dis. 6:483-487.

149. Freudenberg, N., M. A. Freudenberg, K. Bandara, and C. Galanos. 1985 Distribution and localization of endotoxin in the reticulo-endothelial system (RES) and in the main vessels of the rat during shock. Pathol. Res. Pract. 179:517-527.

150. Frey, E. A., D. S. Miller, T. Gullstein-Jahr, A. Sundan, V. Bazil, T. Espevik, B. B. Finlay, and S. D. Wright. 1992. Soluble CD14 participates in the response of cells to lipopolysaccharide. J. Exp. Med. 176:1665-1671.

151. Galanos, C., and O. Lüderitz. 1975. Electrodialysis of lipopolysaccharides and their conversion to uniform salt forms. Eur. J. Biochem. 54:603-610.

152. Galanos, C., O. Lüderitz, and O. Westphal. 1969. A new method for the extraction of R lipopolysaccharides. Eur. J. Biochem. 9:245-249.

153. Galanos, C., E. T. Rietschel, O. Luderitz, O. Westphal, Y. B. Kim, and D. W. Watson. 1972. Biological activities of lipid A complexed with bovineserum albumin. Eur. J. Biochem. 31:230-233.

154. Gallay, P., C. Barras, P. S. Tobias, T. Calandra, M. P. Glauser, and D. Heumann. 1994. Lipopolysaccharide (LPS)-binding protein in human serum determines the tumor necrosis factor response of monocytes to LPS. J. Infect. Dis. 170:1319-1322.

155. Gallay, P., D. Heumann, D. Le Roy, C. Barras, and M. P. Glauser. 1993 Lipopolysaccharide-binding protein as a major plasma protein responsible for endotoxemic shock. Proc. Natl. Acad. Sci. USA 90:9935-9938.

156. Gallay, P., D. Heumann, D. Le Roy, C. Barras, and M. P. Glauser. 1994 Mode of action of anti-lipopolysaccharide-binding protein antibodies for prevention of endotoxemic shock in mice. Proc. Natl. Acad. Sci. USA 91:7922-7926.

157. Gallay, P., C. V. Jongeneel, C. Barras, M. Burnier, J. D. Baumgartner, M. P. Glauser, and D. Heumann. 1993. Short time exposure to lipopolysaccharide is sufficient to activate human monocytes. J. Immunol. 150:50865093.

158. Gazzano-Santoro, H., K. Mészáros, C. Birr, S. F. Carroll, G. Theofan, A. H. Horwitz, E. Lim, S. Aberle, H. Kasler, and J. B. Parent. 1994. Competition between rBP123, a recombinant fragment of bactericidal/permeability-increasing protein, and lipopolysaccharide (LPS)-binding protein for binding to LPS and gram-negative bacteria. Infect. Immun. 62:1185-1191.

159. Gazzano-Santoro, H., J. B. Parent, P. J. Conlon, G. H. Kasler, C. M. Tsai, D. A. Lill-Elghanian, and R. I. Hollingsworth. 1995. Characterization of the structural elements in lipid A required for binding of a recombinant fragment of bactericidal/permeability-increasing protein rBPI23. Infect. Immun. 63:2201-2205.

160. Gazzano-Santoro, H., J. B. Parent, L. Grinna, A. Horwitz, T. Parsons, G. Theofan, P. Elsbach, J. Weiss, and P. J. Conlon. 1992. High-affinity binding of the bactericidal/permeability-increasing protein and a recombinant amino-terminal fragment to the lipid A region of lipopolysaccharide. Infect. Immun. 60:4754-4761.

161. Geerdes, H. F., D. Ziegler, H. Lode, M. Hund, A. Loehr, W. Fangmann, and J. Wagner. 1992. Septicemia in 980 patients at a university hospital in Berlin: prospective studies during 4 selected years between 1979 and 1989 Clin. Infect. Dis. 15:991-1002.

162. Geerts, A., P. De Bleser, M. L. Hautekeete, T. Niki, and E. Wisse. 1994 Fat-storing (Ito) cell biology, p. 819-838. In I. M. Arias, J. L. Boyer, N.
Fausto, W. B. Jakoby, D. A. Schachter, and D. A. Shafritz (ed.), The liver: biology and pathobiology. Raven Press, New York, N.Y.

163. Gegner, J. A., R. J. Ulevitch, and P. S. Tobias. 1995. Lipopolysaccharide (LPS) signal transduction and clearance: dual roles for LPS binding protein and membrane CD14. J. Biol. Chem. 270:5320-5325.

164. Gessani, S., U. Testa, B. Varano, P. Di Marzio, P. Borghi, L. Conti, T. Barberi, E. Tritarelli, R. Martucci, D. Seripa, C. Peschle, and F. Belardelli. 1993. Enhanced production of LPS-induced cytokines during differentiation of human monocytes to macrophages. J. Immunol. 151:3758-3766.

165. Giesbrecht, P., T. Kersten, H. Maidhof, and J. Wecke. 1998. Staphylococcal cell wall: morphogenesis and fatal variations in the presence of penicillin. Microbiol. Mol. Biol. Rev. 62:1371-1414.

166. Ginsberg, H. N. 1998. Lipoprotein physiology. Endocrinol. Metab. Clin. North Am. 27:503-519.

167. Giroir, B. P., P. A. Quint, P. Barton, E. A. Kirsch, L. Kitchen, B. Goldstein, B. J. Nelson, N. I. Wedel, S. F. Carroll, and P. J. Scannon. 1997. Preliminary evaluation of recombinant amino-terminal fragment of human bactericidal/ permeability-increasing protein in children with severe meningococcal sepsis. Lancet 350:1439-1443.

168. Glauser, M. P., G. Zanetti, J. D. Baumgartner, and J. Cohen. 1991. Septic shock: pathogenesis. Lancet 338:732-736.

169. Golenbock, D. T., R. Y. Hampton, N. Qureshi, K. Takayama, and C. R. H. Raetz. 1991. Lipid A-like molecules that antagonize the effects of endotoxins on human monocytes. J. Biol. Chem. 266:19490-19498.

170. Golenbock, D. T., Y. Liu, F. H. Millham, M. W. Freeman, and R. A. Zoeller. 1993. Surface expression of human CD14 in Chinese hamster ovary fibroblasts imparts macrophage-like responsiveness to bacterial endotoxin. J. Biol. Chem. 268:22055-22059.

171. Gordon, B. R., T. S. Parker, D. M. Levine, S. D. Saal, J. C. Wang, B. J. Sloan, P. S. Barie, and A. L. Rubin. 1996. Low lipid concentrations in critical illness: implications for preventing and treating endotoxemia. Crit. Care Med. 24:584-589.

172. Gray, B. H., J. R. Haseman, and K. H. Mayo. 1995. BPI-derived synthetic peptides: synergistic effects in tethered bactericidal and endotoxin neutralizing peptides. Biochim. Biophys. Acta 1244:185-190.

173. Greenberg, J. W., W. Fischer, and K. A. Joiner. 1996. Influence of lipoteichoic acid structure on recognition by the macrophage scavenger receptor. Infect. Immun. 64:3318-3325.

174. Greenman, R. L., R. M. H. Schein, M. A. Martin, R. P. Wenzel, N. R. MacIntyre, G. Emmanuel, H. Chmel, R. B. Kohler, M. McCarthy, J. Plouffe, J. A. Russell, and the XOMA Sepsis Study Group. 1991. A controlled clinical trial of E5 murine monoclonal IgM antibody to endotoxin in the treatment of gram-negative sepsis. JAMA 266:1097-1102.

175. Grewe, M., R. Gausling, K. Gyufko, R. Hoffmann, and K. Decker. 1994. Regulation of the mRNA expression for tumor necrosis factor- $\alpha$ in rat liver macrophages. J. Hepatol. 20:811-818.

176. Grube, B. J., C. G. Cochane, R. D. Ye, C. E. Green, M. E. McPhail, R. J. Ulevitch, and P. S. Tobias. 1994. Lipopolysaccharide binding protein expression in primary human hepatocytes and HepG2 hepatoma cells. J. Biol. Chem. 269:8477-8482.

177. Grunfeld, C., M. Marshall, J. K. Shigenaga, A. H. Moser, P. Tobias, and K. R. Feingold. 1999. Lipoproteins inhibit macrophage activation by lipoteichoic acid. J. Lipid Res. 40:245-252.

178. Gupta, D., Y. P. Jin, and R. Dziarski. 1995. Peptidoglycan induces transcription and secretion of TNF- $\alpha$ and activation of Lyn, extracellular signalregulated kinase, Rsk signal transduction proteins in mouse macrophages. J. Immunol. 155:2620-2630.

179. Hack, C. E., L. A. Aarden, and L. G. Thijs. 1997. Role of cytokines in sepsis. Adv. Immunol. 66:101-195.

180. Haeney, M. R. 1998. The role of the complement cascade in sepsis. J Antimicrob. Chemother. 41(Suppl. A):41-46.

181. Hagiwara, S. I., M. Takeya, H. Suzuki, T. Kodama, L. J. van der Laan, G. Kraal, N. Kitamura, and K. Takahashi. 1999. Role of macrophage scavenger receptors in hepatic granuloma formation in mice. Am. J. Pathol. 154:705-720

182. Hailman, E., J. Albers, G. Wolfbauer, A. Y. Tu, and S. D. Wright. 1996. Neutralization and transfer of lipopolysaccharide by phospholipid transfer protein. J. Biol. Chem. 271:12172-12178.

183. Hailman, E., T. Vasselon, M. Kelley, L. A. Busse, M. C. T. Hu, H. Lichenstein, P. A. Detmers, and S. D. Wright. 1996. Stimulation of macrophages and neutrophils by complexes of lipopolysaccharide and soluble CD14. J. Immunol. 156:4384-4390.

184. Hajjar, A. M., D. S. O'Mahony, A. Ozinsky, D. M. Underhill, A. Aderem, S. J. Klebanoff, and C. B. Wilson. 2001. Cutting edge: functional interactions between toll-like receptor (TLR) 2 and TLR1 or TLR6 in response to phenol-soluble modulin. J. Immunol. 166:15-19.

185. Hampton, R. Y., D. T. Golenbock, M. Penman, M. Krieger, and C. R. H. Raetz. 1991. Recognition and plasma clearance of endotoxin by scavenger receptors. Nature 352:342-352.

186. Hampton, R. Y., and C. R. H. Raetz. 1991. Macrophage catabolism of lipid A is regulated by endotoxin stimulation. J. Biol. Chem. 266:19499-19509.

187. Han, J., J. C. Mathison, R. J. Ulevitch, and P. S. Tobias. 1994. Lipopoly- 
saccharide (LPS) binding protein, truncated at Ile-197, binds LPS but does not transfer LPS to CD14. J. Biol. Chem. 269:8172-8175.

188. Hara-Kuge, S., F. Amano, M. Nishijima, and Y. Akamatsu. 1990. Isolation of a lipopolysaccharide (LPS)-resistant mutant, with defective LPS binding, of cultured macrophage-like cells. J. Biol. Chem. 265:6606-6610.

189. Hardardottir, I., C. Grunfeld, and K. R. Feingold. 1994. Effects of endotoxin and cytokines on lipid metabolism. Curr. Opin. Lipidol. 5:207-215.

190. Hardardottir, I., A. H. Moser, J. Fuller, C. Fielding, K. Feingold, and C. Grunfeld. 1996. Endotoxin and cytokines decrease serum levels and extra hepatic protein and mRNA levels of cholesteryl ester transfer protein in syrian hamsters. J Clin. Investis. 97:2585-2592.

191. Hardardóttir, I., J. Sipe, A. H. Moser, C. J. Fielding, K. R. Feingold, and C Grünfeld. 1997. LPS and cytokines regulate extra hepatic mRNA levels of apolipoproteins during the acute phase response in Syrian hamsters. Biochim. Biophys. Acta 1344:210-220.

192. Hardonk, M. J., F. W. J. Dijkhuis, C. E. Hulstaert, and J. Koudstaal. 1992 Heterogeneity of rat liver and spleen macrophages in gadolinium chlorideinduced elimination and repopulation. J. Leukoc. Biol. 52:296-302.

193. Harris, H. W., E. B. Eichbaum, J. P. Kane, and J. H. Rapp. 1991. Detection of endotoxin in triglyceride-rich lipoproteins in vitro. J. Lab. Clin. Med. 118:186-193.

194. Harris, H. W., C. Grunfeld, K. R. Feingold, and J. H. Rapp. 1990. Human very low density lipoproteins and chylomicrons can protect against endotoxin-induced death in mice. J. Clin. Investig. 86:696-702.

195. Harris, H. W., C. Grunfeld, K. R. Feingold, T. E. Read, J. P. Kane, A. L. Jones, E. B. Eichbaum, G. F. Bland, and J. H. Rapp. 1993. Chylomicrons alter the fate of endotoxin, decreasing tumor necrosis factor release and preventing death. J. Clin. Investig. 91:1028-1034.

196. Harris, H. W., D. C. Rockey, and P. Chau. 1998. Chylomicrons alter the hepatic distribution and cellular response to endotoxin in rats. Hepatology 27:1341-1348.

197. Hashimoto, N., T. Watanabe, Y. Shiratori, Y. Ikeda, K. K. Han, H. Yamada, H. Mitsui, H. Maekawa, Y. Okada, M. Kashiwagi, K. Kurokawa, H. Kato, and G. Toda. 1993. Production of prostanoids by cultured hepatic endothelial cells and their interaction to hepatic parenchymal cells, p. 36-39. In D. L. Knook and E. Wisse (ed.), Cells of the hepatic sinusoid. Kupffer Cell Foundation, Leiden, The Netherlands.

198. Haworth, R., N. Platt, S. Keshav, D. Hughes, E. Darley, H. Suzuki, Y. Kurihara, T. Kodama, and S. Gordon. 1997. The macrophage scavenger receptor type $\mathrm{A}$ is expressed by activated macrophages and protects the host against lethal endotoxic shock. J. Exp. Med. 186:1431-1439.

199. Hayashi, F., K. D. Smith, A. Ozinsky, T. R. Hawn, E. C. Yi, D. R. Goodlett, J. K. Eng, S. Akira, D. M. Underhill, and A. Aderem. 2001. The innate immune response to bacterial flagellin is mediated by Toll-like receptor 5 . Nature 410:1099-1103.

200. Haziot, A., E. Ferrero, F. Köntgen, N. Hijiya, S. Yamamoto, J. Silver, C. L Stewart, and S. M. Goyert. 1996. Resistance to endotoxic shock and reduced dissemination of Gram-negative bacteria in CD14-deficient mice. Immunity 4:407-414.

201. Haziot, A., N. Hijiya, S. C. Gangloff, J. Silver, and S. M. Goyert. 2001 Induction of a novel mechanism of accelerated bacterial clearance by lipopolysaccharide in CD14-deficient and toll-like receptor 4-deficient mice. J. Immunol. 166:1075-1078.

202. Haziot, A., N. Hijiya, K. Schultz, F. Zhang, S. C. Gangloff, and S. M. Goyert. 1999. CD14 plays no major role in shock induced by Staphylococcus aureus but down-regulates TNF-alpha production. J. Immunol. 162:48014805

203. Haziot, A., G. W., Rong, V. Bazil, J. Silver, and S. M. Goyert. 1994. Recombinant soluble CD14 inhibits LPS-induced tumor necrosis factor- $\alpha$ production by cells in whole blood. J. Immunol. 152:5868-5876.

204. Haziot, A., G. W. Rong, X. Y. Lin, J. Silver, and S. M. Goyert. 1995. Recombinant soluble CD14 prevents mortality in mice treated with endotoxin (lipopolysaccharide). J. Immunol. 154:6529-6532.

205. Haziot, A., B. Z. Tsuberi, and S. M. Goyert. 1993. Neutrophil CD14 biochemical properties and role in the secretion of tumor necrosis factor- $\alpha$ in response to lipopolysaccharide. J. Immunol. 150:5556-5565.

206. Heinzel, F. P., R. M. Rerko, P. Ling, J. Hakimi, and D. S. Schoenhaut. 1994 Interleukin 12 is produced in vivo during endotoxemia and stimulates synthesis of gamma interferon. Infect. Immun. 62:4244-4249.

207. Heinzelmann, M., M. A. Mercer-Jones, H. Flodgaard, and F. N. Miller 1998. Heparin-binding protein (CAP37) is internalized in monocytes and increases LPS-induced monocyte activation. J. Immunol. 160:5530-5536.

208. Heinzelmann, M., A. Platz, H. Flodgaard, and F. N. Miller. 1998. Heparin binding protein (CAP37) is an opsonin for Staphylococcus aureus and increases phagocytosis in monocytes. Inflammation 22:493-507.

209. Hellman, J., P. M. Loiselle, M. M. Tehan, J. E. Allaire, L. A. Boyle, J. T. Kurnick, D. M. Andrews, K. K. Sik, and H. S. Warren. 2000. Outer membrane protein A, peptidoglycan-associated lipoprotein, and murein lipoprotein are released by Escherichia coli bacteria into serum. Infect. Immun. 68:2566-2572.

210. Hemmi, H., O. Takeuchi, T. Kawai, T. Kaisho, S. Sato, H. Sanjo, M.
Matsumoto, K. Hoshino, H. Wagner, K. Takeda, and S. Akira. 2000. A Toll-like receptor recognizes bacterial DNA. Nature 408:740-745.

211. Henneke, P., O. Takeuchi, J. A. Van Strijp, H. K. Guttormsen, J. A. Smith, A. B. Schromm, T. A. Espevik, S. Akira, V. Nizet, D. L. Kasper, and D. T. Golenbock. 2001. Novel engagement of CD14 and multiple toll-like receptors by group B streptococci. J. Immunol. 167:7069-7076.

212. Hether, N. W., and L. L. Jackson. 1983. Lipoteichoic acid from Listeria monocytogenes. J. Bacteriol. 156:809-817.

213. Hickey, M. J., K. A. Sharkey, E. G. Sihota, P. H. Reinhardt, J. D. MacMicking, C. Nathan, and P. Kubes. 1997. Inducible nitric oxide synthasedeficient mice have enhanced leukocyte-endothelium interactions in endotoxemia. FASEB J. 11:955-964.

214. Hiemstra, P. S., P. B. Eisenhauer, S. S. L. Harwig, M. T. Van Den Barselaar, R. Van Furth, and R. I. Lehrer. 1993. Antimicrobial proteins of murine macrophages. Infect. Immun. 61:3038-3046.

215. Hirschfeld, M., C. J. Kirschning, R. Schwandner, H. Wesche, J. H. Weis, R. M. Wooten, and J. J. Weis. 1999. Cutting edge: inflammatory signaling by Borrelia burgdorferi lipoproteins is mediated by toll-like receptor 2. J. Immunol. 163:2382-2386.

216. Hirschfeld, M., Y. Ma, J. H. Weis, S. N. Vogel, and J. J. Weis. 2000. Cutting edge: repurification of lipopolysaccharide eliminates signaling through both human and murine toll-like receptor 2. J. Immunol. 165:618-622.

217. Hmama, Z., A. Mey, G. Normier, H. Binz, and J. P. Revillard. 1994. CD14 and CD11b mediate serum-independent binding to human monocytes of an acylpolygalactoside isolated from Klebsiella pneumoniae. Infect. Immun. 62:1520-1527.

218. Horn, K. D. 1998. Evolving strategies in the treatment of sepsis and systemic inflammatory response syndrome (SIRS). Q. J. Med. 91:265-277.

219. Hornung, V., S. Rothenfusser, S. Britsch, A. Krug, B. Jahrsdorfer, T. Giese, S. Endres, and G. Hartmann. 2002. Quantitative expression of toll-like receptor 1-10 mRNA in cellular subsets of human peripheral blood mononuclear cells and sensitivity to $\mathrm{CpG}$ oligodeoxynucleotides. J. Immunol. 168:4531-4537.

220. Horwitz, A. H., R. E. Williams, and G. Nowakowski. 1995. Human lipopolysaccharide-binding protein potentiates bactericidal activity of human bactericidal/permeability-increasing protein. Infect. Immun. 63:522-527.

221. Hoshino, K., O. Takeuchi, T. Kawai, H. Sanjo, T. Ogawa, Y. Takeda, K. Takeda, and S. Akira. 1999. Cutting edge: toll-like receptor 4 (TLR4)deficient mice are hyporesponsive to lipopolysaccharide: evidence for TLR4 as the Lps gene product. J. Immunol. 162:3749-3752.

222. Hsu, H. Y., D. P. Hajjar, K. M. Khan, and D. J. Falcone. 1998. Ligand binding to macrophage scavenger receptor-A induces urokinase-type plasminogen activator expression by a protein kinase-dependent signaling pathway. J. Biol. Chem. 273:1240-1246.

223. Hsueh, W., X. Sun, L. N. Rioja, and F. Gonzalez-Crussi. 1990. The role of the complement system in shock and tissue injury induced by tumour necrosis factor and endotoxin. Immunology 70:309-314.

224. Hubacek, J. A., C. Büchler, C. Aslanidis, and G. Schmitz. 1997. The genomic organization of the genes for human lipopolysaccharide binding protein (LBP) and bactericidal permeability increasing protein (BPI) is highly conserved. Biochem. Biophys. Res. Commun. 236:427-430.

225. Hubsch, A. P., A. T. Casas, and J. E. Doran. 1995. Protective effects of reconstituted high-density lipoprotein in rabbit gram-negative bacteremia models. J. Lab. Clin. Med. 126:548-558.

226. Hubsch, A. P., F. S. Powell, P. G. Lerch, and J. E. Doran. 1993. A reconstituted, apolipoprotein A-I containing lipoprotein reduces tumor necrosis factor release and attenuates shock in endotoxemic rabbits. Circ. Shock 40:14-23.

227. Hughes, D. A., I. P. Fraser, and S. Gordon. 1995. Murine macrophage scavenger receptor: in vivo expression and function as a receptor for macrophage adhesion in lymphoid and non-lymphoid organs. Eur. J. Immunol 25:466-473.

228. Hui, D. Y., J. A. Harmony, T. L. Innerarity, and R. W. Mahley. 1980 Immunoregulatory plasma lipoproteins. Role of apoprotein E and apoprotein B. J Biol. Chem. 255:11775-11781.

229. Hummell, D. S., A. J. Swift, A. Tomasz, and J. A. Winkelstein. 1985. Activation of the alternative complement pathway by pneumococcal lipoteichoic acid. Infect. Immun. 47:384-387.

230. Hwang, D. 2001. Modulation of the expression of cyclooxygenase-2 by fatty acids mediated through toll-like receptor 4-derived signaling pathways. FASEB J. 15:2556-2564.

231. Iimuro, Y., M. Yamamoto, H. Kohno, J. Itakura, H. Fujii, and Y. Matsumoto. 1994. Blockade of liver macrophages by gadolinium chloride reduces lethality in endotoxemic rats-analysis of mechanisms of lethality in endotoxemia. J. Leukoc. Biol. 55:723-728.

232. Ingalls, R. R., M. A. Arnaout, and D. T. Golenbock. 1997. Outside-in signaling by lipopolysaccharide through a tailless integrin. J. Immunol 159:433-438.

233. Ingalls, R. R., and D. T. Golenbock. 1995. CD11c/CD18, a transmembrane signaling receptor for lipopolysaccharide. J. Exp. Med. 181:1473-1479.

234. Ingalls, R. R., B. G. Monks, R. Savedra, Jr., W. J. Christ, R. L. Delude, A. E. 
Medvedev, T. Espevik, and D. T. Golenbock. 1998. CD11/CD18 and CD14 share a common lipid A signaling pathway. J. Immunol. 161:5413-5420.

235. Innerarity, T. L., E. J. Friedlander, S. C. Rall, Jr., K. H. Weisgraber, and R. W. Mahley. 1983. The receptor-binding domain of human apolipoprotein E. Binding of apolipoprotein E fragments. J. Biol. Chem. 258:1234112347.

236. Ishiguro, T., M. Naito, T. Yamamoto, G. Hasegawa, F. Gejyo, M. Mitsuyama, H. Suzuki, and T. Kodama. 2001. Role of macrophage scavenger receptors in response to Listeria monocytogenes infection in mice. Am. J. Pathol. 158:179-188.

237. Itoh, Y., T. Okanoue, F. Enjyo, Y. Nagao, T. Mori, S. Sakamoto, and K. Kashima. 1993. Regulation of hepatocyte acute phase proteins by Kupffer cells: implications for the involvement of nitric oxide, p. 70-71. In D. L. Knook and E. Wisse (ed.), Cells of the hepatic sinusoid. Kupffer Cell Foundation, Leiden, The Netherlands.

238. Iwagaki, A., M. Porro, and M. Pollack. 2000. Influence of synthetic antiendotoxin peptides on lipopolysaccharide (LPS) recognition and LPS-induced proinflammatory cytokine responses by cells expressing membranebound CD14. Infect. Immun. 68:1655-1663.

239. Iwami, K., T. Matsuguchi, A. Masuda, T. Kikuchi, T. Musikacharoen, and Y. Yoshikai. 2000. Cutting edge: naturally occurring soluble form of mouse toll-like receptor 4 inhibits lipopolysaccharide signaling. J Immunol. 165: 6682-6686.

240. Jack, R. S., X. Fan, M. Bernheiden, G. Rune, M. Ehlers, A. Weber, G. Kirsch, R. Mentel, B. Furll, M. Freudenberg, G. Schmitz, F. Stelter, and C. Schutt. 1997. Lipopolysaccharide-binding protein is required to combat a murine gram-negative bacterial infection. Nature 389:742-745.

241. Jaeschke, H. 1996. Chemokines, neutrophils, and inflammatory liver injury. Shock 6:403-404.

242. Jaeschke, H., and C. W. Smith. 1997. Cell adhesion and migration. III Leukocyte adhesion and transmigration in the liver vasculature. Am. J. Physiol. 273:G1169-G1173.

243. Ji, Z. S., S. Fazio, Y. L. Lee, and R. W. Mahley. 1994. Secretion-capture role for apolipoprotein $\mathrm{E}$ in remnant lipoprotein metabolism involving cell surface heparan sulfate proteoglycans. J Biol. Chem. 269:2764-2772.

244. Jiang, Q., S. Akashi, K. Miyake, and H. R. Petty. 2000. Lipopolysaccharide induces physical proximity between CD14 and toll-like receptor 4 (TLR4) prior to nuclear translocation of NF-кB. J. Immunol. 165:3541-3544.

245. Jiang, X. C., and C. Bruce. 1995. Regulation of murine plasma phospholipid transfer protein activity and mRNA levels by lipopolysaccharide and high cholesterol diet. J. Biol. Chem. 270:17133-17138.

246. Joiner, K. A., R. Goldman, M. Schmetz, M. Berger, C. H. Hammer, M. M. Frank, and L. Leive. 1984. A quantitative analysis of C3 binding to Oantigen capsule, lipopolysaccharide, and outer membrane protein of $E$. col O111B4. J. Immunol. 132:369-375.

247. Jovinge, S., M. P. S. Ares, B. Kallin, and J. Nilsson. 1996. Human monocytes/macrophages release TNF- $\alpha$ in response to ox-LDL. Arterioscler. Thromb. Vasc. Biol. 16:1573-1579.

248. Juan, T. S. C., E. Hailman, M. J. Kelley, L. A. Busse, E. Davy, C. J. Empig, L. O. Narhi, S. D. Wright, and H. S. Lichenstein. 1995. Identification of a lipopolysaccharide binding domain in CD14 between amino acids 57 and 64. J. Biol. Chem. 270:5219-5224.

249. Juan, T. S. C., E. Hailman, M. J. Kelley, S. D. Wright, and H. S. Lichenstein. 1995. Identification of a domain in soluble CD14 essential for lipopolysaccharide (LPS) signaling but not LPS binding. J. Biol. Chem. 270: $17237-17242$

250. Juan, T. S. C., M. J. Kelley, D. A. Johnson, L. A. Busse, E. Hailman, S. D. Wright, and H. S. Lichenstein. 1995. Soluble CD14 truncated at amino acid 152 binds lipopolysaccharide (LPS) and enables cellular response to LPS. J. Biol. Chem. 270:1382-1387.

251. Karima, R., S. Matsumoto, H. Higashi, and K. Matsushima. 1999. The molecular pathogenesis of endotoxic shock and organ failure. Mol. Med. Today 5:123-132.

252. Katori, M., and M. Majima. 2000. Cyclooxygenase-2: its rich diversity of roles and possible application of its selective inhibitors. Inflamm. Res. 49:367-392.

253. Katz, S. S., Y. Weinrauch, R. S. Munford, P. Elsbach, and J. Weiss. 1999 Deacylation of lipopolysaccharide in whole Escherichia coli during destruction by cellular and extracellular components of a rabbit peritoneal inflammatory exudate. J. Biol. Chem. 274:36579-36584.

254. Kawada, N., Y. Mizoguchi, K. Kobayashi, T. Monna, S. Morisawa, N. Ueda, Y. Omoto, Y. Takahashi, and S. Yamamoto. 1992. Possible induction of fatty acid cyclo-oxygenase in lipopolysaccharide-stimulated rat Kupffer cells. Gastroenterology 103:1026-1033.

255. Kawai, T., O. Adachi, T. Ogawa, K. Takeda, and S. Akira. 1999. Unresponsiveness of MyD88-deficient mice to endotoxin. Immunity 11:115-122.

256. Kawakami, M., and A. Cerami. 1981. Studies of endotoxin-induced decrease in lipoprotein lipase activity. J. Exp. Med. 154:631-639.

257. Kawakami, M., P. H. Pekala, M. D. Lane, and A. Cerami. 1982. Lipoprotein lipase suppression in 3T3-L1 cells by an endotoxin-induced mediator from exudate cells. Proc. Natl. Acad. Sci. USA 79:912-916.

258. Kawamura, N., N. Imanishi, H. Koike, H. Nakahara, L. Phillips, and S.
Morooka. 1995. Lipoteichoic acid-induced neutrophil adhesion via E-selectin to human umbilical vein endothelial cells (HUVECs). Biochem. Biophys. Res. Commun. 217:1208-1215.

259. Keller, R., W. Fischer, R. Keist, and S. Bassetti. 1992. Macrophage response to bacteria: induction of marked secretory and cellular activities by lipoteichoic acids. Infect. Immun. 60:3664-3672.

260. Kellogg, T. A., C. A. Weiss III, J. W. Johnston, K. R. Wasiluk, and D. L. Dunn. 1999. Antiendotoxin agents share molecular homology within their lipopolysaccharide binding domains. J. Surg. Res. 85:136-141.

261. Kengatharan, K. M., S. De Kimpe, C. Robson, S. J. Foster, and C. Thiemermann. 1998. Mechanism of gram-positive shock: identification of peptidoglycan and lipoteichoic acid moieties essential in the induction of nitric oxide synthase, shock, and multiple organ failure. J. Exp. Med. 188:305315.

262. Kengatharan, K. M., S. J. De Kimpe, and C. Thiemermann. 1996. Role of nitric oxide in the circulatory failure and organ injury in a rodent model of gram-positive shock. Br. J. Pharmacol. 119:1411-1421.

263. Kengatharan, M., S. J. De Kimpe, and C. Thiemermann. 1996. Analysis of the signal transduction in the induction of nitric oxide synthase by lipoteichoic acid in macrophages. Br. J. Pharmacol. 117:1163-1170.

264. Kirikae, T., M. Hirata, H. Yamasu, F. Kirikae, H. Tamura, F. Kayama, K. Nakatsuka, T. Yokochi, and M. Nakano. 1998. Protective effects of a human 18-kilodalton cationic antimicrobial protein (CAP18)-derived peptide against murine endotoxemia. Infect. Immun. 66:1861-1868.

265. Kirkland, T. N., F. Finley, D. J. Leturcq, A. M. Moriarty, J. D. Lee, R. J. Ulevitch, and P. S. Tobias. 1993. Analysis of lipopolysaccharide binding by CD14. J. Biol. Chem. 268:24818-24823.

266. Kirschning, C. J., J. Au-Young, N. Lamping, D. Reuter, D. Pfeil, J. J. Seilhamer, and R. R. Schumann. 1997. Similar organization of the lipopolysaccharide-binding protein (LBP) and phospholipid transfer protein (PLTP) genes suggests a common gene family of lipid-binding proteins. Genomics 46:416-425.

267. Kirschning, C. J., H. Wesche, A. T. Merrill, and M. Rothe. 1998. Human toll-like receptor 2 confers responsiveness to bacterial lipopolysaccharide. J. Exp. Med. 188:2091-2097.

268. Kitchens, R. L., and R. S. Munford. 1995. Enzymatically deacylated lipopolysaccharide (LPS) can antagonize LPS at multiple sites in the LPS recognition pathway. J. Biol. Chem. 270:9904-9910.

269. Kitchens, R. L., G. Wolfbauer, J. J. Albers, and R. S. Munford. 1999. Plasma lipoproteins promote the release of bacterial lipopolysaccharide from the monocyte cell surface. J. Biol. Chem. 274:34116-34122.

270. Klein, A., M. Zhadkewich, J. Margolick, J. Winkelstein, and G. Bulkley. 1994. Quantitative discrimination of hepatic reticuloendothelial clearance and phagocytic killing. J. Leukoc. Biol. 55:248-252.

271. Kobayashi, Y., C. Miyaji, H. Watanabe, H. Umezu, G. Hasegawa, T. Abo, M. Arakawa, N. Kamata, H. Suzuki, T. Kodama, and M. Naito. 2000. Role of macrophage scavenger receptor in endotoxin shock. J. Pathol. 192:263272.

272. Koch, H. U., R. Doker, and W. Fischer. 1985. Maintenance of D-alanine ester substitution of lipoteichoic acid by reesterification in Staphylococcus aureus. J. Bacteriol. 164:1211-1217.

273. Kodama, T., M. Freeman, L. Rohrer, J. Zabrecky, P. Matsudaira, and M. Krieger. 1990. Type I macrophage scavenger receptor contains $\alpha$-helical and collagen-like coiled coils. Nature 343:531-535.

274. Kotani, S., H. Takada, M. Tsujimoto, T. Ogawa, I. Takahashi, T. Ikeda, K. Otsuka, H. Shimauchi, N. Kasai, J. Mashimo, S. Nagao, A. Tanaka, S. Tanaka, K. Harada, K. Nagaki, H. Kitamura, T. Shiba, S. Kusumoto, M. Imoto, and H. Yoshimura. 1985. Synthetic lipid A with endotoxic and related biological activities comparable to those of a natural lipid A from an Escherichia coli Re-mutant. Infect. Immun. 49:225-237.

275. Koyama, S., T. Shibamoto, W. S. Ammons, and Y. Saeki. 1995. rBP123 attenuates endotoxin-induced cardiovascular depression in awake rabbits. Shock 4:74-78.

276. Krauss, R. M. C. Grunfeld, W. T. Doerrier, and K. R. Feingold. 1990 Tumor necrosis factor acutely increases plasma levels of very low density lipoproteins of normal size and composition. Endocrinology 127:10161021.

277. Krieger, M., and J. Herz. 1994. Structures and functions of multiligand lipoprotein receptors: macrophage scavenger receptors and LDL receptorrelated protein (LRP). Annu. Rev. Biochem. 63:601-637.

278. Kuiper, J., A. Brouwer, D. L. Knook, and T. J. C. Van Berkel. 1994. Kupffer and sinusoidal endothelial cells, p. 791-818. In I. M. Arias, J. L. Boyer, N. Fausto, W. B. Jakoby, D. A. Schachter, and D. A. Shafritz (ed.), The liver: biology and pathobiology. Raven Press, New York, N.Y.

279. Kuiper, J., F. J. Zijlstra, J. A. A. M. Kamps, and T. J. C. Van Berkel. 1988 Identification of prostaglandin D2 as the major eicosanoid from liver endothelial and Kupffer cells. Biochim. Biophys. Acta 959:143-152.

280. Kuipers, B., T. Van Der Poll, M. Levi, S. J. H. Van Deventer, H. Ten Cate, Y. Imai, E. Hack, and J. W. Ten Cate. 1994. Platelet-activating factor antagonist TCV-309 attenuates the induction of the cytokine network in experimental endotoxemia in chimpanzees. J. Immunol. 152:2438-2446.

281. Kuipers, F., M. C. Jong, Y. Lin, M. Eck, R. Havinga, V. Bloks, H. J. 
Verkade, M. H. Hofker, H. Moshage, T. J. Berkel, R. J. Vonk, and L. M. Havekes. 1997. Impaired secretion of very low density lipoprotein-triglycerides by apolipoprotein E-deficient mouse hepatocytes. J. Clin. Investig. 100:2915-2922.

282. Kurt-Jones, E. A., L. Popova, L. Kwinn, L. M. Haynes, L. P. Jones, R. A Tripp, E. E. Walsh, M. W. Freeman, D. T. Golenbock, L. J. Anderson, and R. W. Finberg. 2000. Pattern recognition receptors TLR4 and CD14 mediate response to respiratory syncytial virus. Nat. Immunol. 1:398-401.

283. Kusunoki, T., E. Hailman, T. S. C. Juan, H. S. Lichenstein, and S. D. Wright. 1995. Molecules from Staphylococcus aureus that bind CD14 and stimulate innate immune responses. J. Exp. Med. 182:1673-1682.

284. Kusunoki, T. and S. D. Wright. 1996. Chemical characteristics of Staphylococcus aureus molecules that have CD14-dependent cell-stimulatory activity. J. Immunol. 157:5112-5117.

285. Labeta, M. O., J. J. Durieux, N. Fernandez, F. Herrmann, and P. Ferrara 1993. Release from a human monocyte-like cell line of two different soluble forms of the lipopolysaccharide receptor, CD14. Eur. J. Immunol. 23:21442151.

286. Labeta, M. O., K. Vidal, J. E. Nores, M. Arias, N. Vita, B. P. Morgan, J. C Guillemot, D. Loyaux, P. Ferrara, D. Schmid, M. Affolter, L. K. Borysiewicz, A. Donnet-Hughes, and E. J. Schiffrin. 2000. Innate recognition of bacteria in human milk is mediated by a milk-derived highly expressed pattern recognition receptor, soluble CD14. J. Exp. Med. 191:1807-1812.

287. Lagrost, L., C. Desrumaux, D. Masson, V. Deckert, and P. Gambert. 1998 Structure and function of the plasma phospholipid transfer protein. Curr. Opin. Lipidol. 9:203-209.

288. LaMarre, J., B. B. Wolf, E. L. Kittler, P. J. Quesenberry, and S. L. Gonias 1993. Regulation of macrophage alpha 2-macroglobulin receptor/low density lipoprotein receptor-related protein by lipopolysaccharide and interferon- $\gamma$. J. Clin. Investig. 91:1219-1224.

289. Lamping, N., R. Dettmer, N. W. Schroder, D. Pfeil, W. Hallatschek, R. Burger, and R. R. Schumann. 1998. LPS-binding protein protects mice from septic shock caused by LPS or gram-negative bacteria. J. Clin. Investig. 101:2065-2071.

290. Lamping, N., A. Hoess, B. Yu, T. C. Park, C. Kirschning, D. Pfeil, D. Reuter, S. D. Wright, F. Herrmann, and R. R. Schumann. 1996. Effects of site-directed mutagenesis of basic residues (arg 94, lys 95, lys 99) of lipopolysaccharide (LPS)-binding protein on binding and transfer of LPS and subsequent immune cell activation. J. Immunol. 96:4648-4656.

291. Landmann, R., A. E. Fisscher, and J. P. Obrecht. 1992. Interferon- $\gamma$ and interleukin-4 down-regulate soluble CD14 release in human monocytes and macrophages. J. Leukoc. Biol. 52:323-330.

292. Landmann, R., W. Zimmerli, S. Sansano, S. Link, A. Hahn, M. P. Glauser, and T. Calandra. 1995. Increased circulating soluble CD14 is associated with high mortality in Gram-negative shock. J. Infect. Dis. 171:639-644.

293. Lanza-Jacoby, S., H. Phetteplace, N. Sedkova, and G. Knee. 1998. Sequential alterations in tissue lipoprotein lipase, triglyceride secretion rates, and serum tumor necrosis factor- $\alpha$ during Escherichia coli bacteremic sepsis in relation to the development of hypertriglyceridemia. Shock 9:46-51.

294. Larkin, L., L. M. Khachigian, and W. Jessup. 2000. Regulation of apolipoprotein E production in macrophages. Int. J. Mol. Med. 6:253-258.

295. Larrick, J. W., M. Hirata, R. F. Balint, J. Lee, J. Zhong, and S. C. Wright. 1995. Human CAP18: a novel antimicrobial lipopolysaccharide-binding protein. Infect. Immun. 63:1291-1297.

296. Larrick, J. W., M. Hirata, H. Zheng, J. Zhong, D. Bolin, J. M. Cavaillon, H. S. Warren, and S. C. Wright. 1994. A novel granulocyte-derived peptide with lipopolysaccharide-neutralizing activity. J. Immunol. 152:231-240.

297. Larrick, J. W., J. G. Morgan, I. Palings, M. Hirata, and M. H. Yen. 1991 Complementary DNA sequence of rabbit CAP18-a unique lipopolysaccharide binding protein. Biochem. Biophys. Res. Commun. 179:170-175.

298. Laskin, D. L., D. E. Heck, C. R. Gardner, L. S. Feder, and J. D. Laskin. 1994. Distinct patterns of nitric oxide production in hepatic macrophages and endothelial cells following acute exposure of rats to endotoxin. J. Leukoc. Biol. 56:751-758.

299. Laskowitz, D. T., S. Goel, E. R. Bennett, and W. D. Matthew. 1997. Apolipoprotein E suppresses glial cell secretion of TNF- $\alpha$. J. Neuroimmunol. 76:70-74.

300. Reference deleted.

301. Lee, H. K., J. Lee, and P. S. Tobias. 2002. Two lipoproteins extracted from Escherichia coli K-12 LCD25 lipopolysaccharide are the major components responsible for Toll-like receptor 2-mediated signaling. J. Immunol.168: 4012-4017.

302. Lee, J. D., K. Kato, T. N. Kirkland, and R. J. Ulevitch. 1992. Transfection of CD14 into 70Z/3 cells dramatically enhances the sensitivity to complexes to lipopolysaccharide (LPS) and LPS binding protein. J. Exp. Med. 175: 1697-1705.

303. Lee, J. D., V. Kravchenko, T. N. Kirkland, J. Han, N. Mackman, A. M Moriarty, D. J. Leturcq, P. S. Tobias, and R. J. Ulevitch. 1993. Glycosylphosphatidylinositol-anchored or integral membrane forms of CD14 mediate identical cellular responses to endotoxin. Proc. Natl. Acad. Sci. USA 90:9930-9934.

304. Lee, W. J., J. L. Farmer, M. Hilty, and Y. B. Kim. 1998. The protective effects of lactoferrin feeding against endotoxin lethal shock in germfree piglets. Infect. Immun. 66:1421-1426.

305. Lefering, R. and E. A. Neugebauer. 1995. Steroid controversy in sepsis and septic shock: a meta-analysis. Crit. Care Med. 23:1294-1303.

306. Lemaire, L. C., J. J. van Lanschot, T. Van Der Poll, W. A. Buurman, S. J. van Deventer, and D. J. Gouma. 1998. Lymph of patients with a systemic inflammatory response syndrome inhibits lipopolysaccharide-induced cytokine production. J. Infect. Dis. 178:883-886.

307. Lengacher, S., C. V. Jongeneel, D. Le Roy, J. D. Lee, V. Kravchenko, R. J. Ulevitch, M. P. Glauser, and D. Heumann. 1997. Reactivity of murine and human recombinant LPS-binding protein (LBP) with LPS and Gram negative bacteria. J. Inflamm. 47:165-172.

307a.Le Roy, D., F. Di Padova, R. Tees, S. Lengacher, R. Landmann, M. P. Glauser, T. Calandra, and D. Heumann. 1999. Monoclonal antibodies to murine lipopolysaccharide (LPS)-binding protein (LBP) protect mice from lethal endotoxemia by blocking either the binding of LPS to LBP or the presentation of LPS/LBP complexes to CD14. J. Immunol. 162:7454-7460.

308. Leturcq, D. J., A. M. Moriarty, G. Talbott, R. K. Winn, T. R. Martin, and R. J. Ulevitch. 1996. Antibodies against CD14 protect primates from endotoxin-induced shock. J. Clin. Investig. 98:1533-1538.

309. Levin, M., P. A. Quint, B. Goldstein, P. Barton, J. S. Bradley, S. D. Shemie, T. Yeh, S. S. Kim, D. P. Cafaro, P. J. Scannon, B. P. Giroir, and the rBPI21 Meningococcal Sepsis Study Group. 2000. Recombinant bactericidal/permeability-increasing protein (rBPI21) as adjunctive treatment for children with severe meningococcal sepsis: a randomised trial. Lancet 356:961-967.

310. Levine, D. M., T. S. Parker, T. M. Donnelly, A. Walsh, and A. L. Rubin. 1993. In vivo protection against endotoxin by plasma high density lipoprotein. Proc. Natl. Acad. Sci. USA 90:12040-12044.

311. Levy, O., C. E. Ooi, P. Elsbach, M. E. Doerfler, R. I. Lehrer, and J. Weiss. 1995. Antibacterial proteins of granulocytes differ in interaction with endotoxin. J. Immunol. 154:5403-5410.

312. Li, H., A. Llera, E. L. Malchiodi, and R. A. Mariuzza. 1999. The structural basis of $\mathrm{T}$ cell activation by superantigens. Annu. Rev. Immunol. 17:435466.

313. Liao, W., and C. H. Florén. 1993. Endotoxin, cytokines, and hyperlipidemia. Scand. J. Gastroenterol. 28:97-103.

314. Liao, W., M. Rudling, and B. Angelin. 1999. Endotoxin suppresses mouse hepatic low-density lipoprotein-receptor expression via a pathway independent of the toll-like receptor 4. Hepatology 30:1252-1256.

315. Lichtman, S. N., J. Wang, and J. J. Lemasters. 1998. Lipopolysaccharidestimulated TNF- $\alpha$ release from cultured rat Kupffer cells: sequence of intracellular signaling pathways. J. Leukoc. Biol. 64:368-372.

316. Lichtman, S. N., J. Wang, and J. J. Lemasters. 1998. LPS receptor CD14 participates in release of TNF- $\alpha$ in RAW 264.7 and peritoneal cells but not in Kupffer cells. Am. J. Physiol. Gastrointest. Liver Physiol. 38:G39-G46.

317. Lichtman, S. N., J. Wang, J. H. Schwab, and J. J. Lemasters. 1993. Comparison of peptidoglycan-polysaccharide and lipopolysaccharide stimulation of Kupffer cells to produce tumor necrosis factor and interleukin-1. Hepatology 19:1013-1022.

318. Lien, E., J. C. Chow, L. D. Hawkins, P. D. McGuinness, K. Miyake, T. Espevik, F. Gusovsky, and D. T. Golenbock. 2001. A novel synthetic acyclic lipid A-like agonist activates cells via the lipopolysaccharide/Toll-like receptor 4 signaling pathway. J. Biol. Chem. 276:1873-1880.

319. Lien, E., T. K. Means, H. Heine, A. Yoshimura, S. Kusumoto, K. Fukase, M. J. Fenton, M. Oikawa, N. Qureshi, B. Monks, R. W. Finberg, R. R. Ingalls, and D. T. Golenbock. 2000. Toll-like receptor 4 imparts ligandspecific recognition of bacterial lipopolysaccharide. J. Clin. Investig. 105: 497-504.

320. Lien, E., T. J. Sellati, A. Yoshimura, T. H. Flo, G. Rawadi, R. W. Finberg, J. D. Carroll, T. Espevik, R. R. Ingalls, J. D. Radolf, and D. T. Golenbock. 1999. Toll-like receptor 2 functions as a pattern recognition receptor for diverse bacterial products. J. Biol. Chem. 274:33419-33425.

321. Lin, Y., F. R. Kohn, A. H. C. Kung, and W. S. Ammons. 1994. Protective effect of a recombinant fragment of bactericidal/permeability increasing protein against carbohydrate dyshomeostasis and tumor necrosis factor- $\alpha$ elevation in rat endotoxemia. Biochem. Pharmacol. 47:1553-1559.

322. Liu, S., L. S. Khemlani, R. A. Shapiro, M. L. Johnson, K. Liu, D. A. Geller, S. C. Watkins, S. M. Goyert, and T. R. Billiar. 1998. Expression of CD14 by hepatocytes: upregulation by cytokines during endotoxemia. Infect. Immun. 66:5089-5098.

323. Liu, S., A. N. Salyapongse, D. A. Geller, Y. Vodovotz, and T. R. Billiar. 2000. Hepatocyte toll-like receptor 2 expression in vivo and in vitro: role of cytokines in induction of rat TLR2 gene expression by lipopolysaccharide. Shock 14:361-365.

324. Loos, M., F. Clas, and W. Fischer. 1986. Interaction of purified lipoteichoic acid with the classical complement pathway. Infect. Immun. 53:595-599.

325. Loppnow, H., H. Brade, I. Dürrbaum, C. A. Dinarello, S. Kusumoto, E. T. Rietschel, and H. D. Flad. 1989. IL-1 induction-capacity of defined lipopolysaccharide partial structures. J. Immunol. 142:3229-3238.

326. Lucas, C. E., and A. M. Ledgerwood. 1984. The cardiopulmonary response to massive doses of steroids in patients with septic shock. Arch. Surg. 119:537-541. 
327. Luchi, M., and R. S. Munford. 1993. Binding, internalization, and deacylation of bacterial lipopolysaccharide by human neutrophils. J. Immunol. 151:959-969.

328. Lugtenberg, B., and L. Van Alphen. 1983. Molecular architecture and functioning of the outer membrane of Escherichia coli and other Gramnegative bacteria. Biochim. Biophys. Acta 737:51-115.

329. Luhm, J., A. B. Schromm, U. Seydel, K. Brandenburg, N. Wellinghausen, E. Riedel, R. R. Schumann, and L. Rink. 1998. Hypothermia enhances the biological activity of lipopolysaccharide by altering its fluidity state. Eur. J. Biochem. 256:325-333.

330. Lukacs, N. W., C. Hogaboam, E. Campbell, and S. L. Kunkel. 1999. Chemokines: function, regulation and alteration of inflammatory responses. Chem. Immunol. 72:102-120.

331. Luster, M. I., D. R. Germolec, T. Yoshida, F. Kayama, and M. Thompson. 1994. Endotoxin-induced cytokine gene expression and excretion in the liver. Hepatology 19:480-488.

332. Mahalingam, S., and G. Karupiah. 1999. Chemokines and chemokine receptors in infectious diseases. Immunol. Cell Biol. 77:469-475.

333. Mahley, R. W., and Z. S. Ji. 1999. Remnant lipoprotein metabolism: key pathways involving cell-surface heparan sulfate proteoglycans and apolipoprotein E. J. Lipid Res. 40:1-16.

334. Majcherczyk, P. A., H. Langen, D. Heumann, M. Fountoulakis, M. P Glauser, and P. Moreillon. 1999. Digestion of Streptococcus pneumoniae cell walls with its major peptidoglycan hydrolase releases branched stem peptides carrying proinflammatory activity. J. Biol. Chem. 274:12537-12543.

335. Malhotra, R., and M. I. Bird. 1997. L-selectin-a signalling receptor for lipopolysaccharide. Chem. Biol. 4:543-547.

336. Malhotra, R., R. Priest, and M. I. Bird. 1996. Role for L-selectin in lipopolysaccharide-induced activation of neutrophils. Biochem. J. 320:589-593.

337. Malhotra, R., R. Priest, M. R. Foster, and M. I. Bird. 1998. P-selectin binds to bacterial lipopolysaccharide. Eur. J. Immunol. 28:983-988.

338. Mammen, E. F. 1998. The haematological manifestations of sepsis. J. Antimicrob. Chemother. 41(Suppl. A):17-24.

339. Manthey, C. L., P. Y. Perera, B. E. Henricson, T. A. Hamilton, N. Qureshi, and S. N. Vogel. 1994. Endotoxin-induced early gene expression in $\mathrm{C} 3 \mathrm{H}$ HeJ (Lpsd) macrophages. J. Immunol. 153:2653-2663.

340. Manthey, C. L., and S. N. Vogel. 1994. Elimination of trace endotoxin protein from rough chemotype LPS. J. Endotoxin Res. 1:84-91.

341. Marchant, A., J. Duchow, J. P. Delville, and M. Goldman. 1992. Lipopolysaccharide induces up-regulation of CD14 molecule on monocytes in human whole blood. Eur. J. Immunol. 22:1663-1665.

342. Marin, D. B., B. Breuer, M. L. Marin, J. Silverman, J. Schmeidler, D. Greenberg, S. Flynn, M. Mare, M. Lantz, L. Libow, R. Neufeld, L. Altstiel, K. L. Davis, and R. C. Mohs. 1998. The relationship between apolipoprotein E, dementia, and vascular illness. Atherosclerosis 140:173-180.

343. Marino, M. W., A. Dunn, D. Grail, M. Inglese, Y. Noguchi, E. Richards, A. Jungbluth, H. Wada, M. Moore, B. Williamson, S. Basu, and L. J. Old. 1997. Characterization of tumor necrosis factor-deficient mice. Proc. Natl. Acad. Sci. USA 94:8093-8098.

344. Massari, P., P. Henneke, Y. Ho, E. Latz, D. T. Golenbock, and L. M. Wetzler. 2002. Cutting edge: Immune stimulation by neisserial porins is toll-like receptor 2 and MyD88 dependent. J. Immunol. 168:1533-1537.

345. Mathison, J. C., P. S. Tobias, E. Wolfson, and R. J. Ulevitch. 1992. Plasma lipopolysaccharide (LPS)-binding protein; a key component in macrophage recognition of Gram-negative LPS. J. Immunol. 149:200-206.

346. Mathison, J. C., and R. J. Ulevitch. 1979. The clearance, tissue distribution, and cellular localization of intravenously injected lipopolysaccharide in rabbits. J. Immunol. 123:2133-2143.

347. Mathison, J. C., and R. J. Ulevitch. 1985. Uptake and subcellular localization of bacterial lipopolysaccharide in the adrenal gland. Am. J. Pathol. 120:79-86.

348. Matsuguchi, T., T. Musikacharoen, T. Ogawa, and Y. Yoshikai. 2000. Gene expressions of toll-like receptor 2, but not toll-like receptor 4 , is induced by LPS and inflammatory cytokines in mouse macrophages. J. Immunol. 165: 5767-5772.

349. Matsumura, T., A. Ito, T. Takii, H. Hayashi, and K. Onozaki. 2000. Endotoxin and cytokine regulation of toll-like receptor (TLR) 2 and TLR4 gene expression in murine liver and hepatocytes. J. Interferon Cytokine Res. 20:915-921.

350. Matsuura, K., T. Ishida, M. Setoguchi, Y. Higuchi, S. Akizuki, and S. Yamamoto. 1994. Upregulation of CD14 expression in Kupffer cells by lipopolysaccharide. J. Exp. Med. 179:1671-1676.

351. Mattsby-Baltzer, I., A. Roseanu, C. Motas, J. Elverfors, I. Engberg, and L. A. Hanson. 1996. Lactoferrin or a fragment thereof inhibits the endotoxin-induced interleukin- 6 response in human monocytic cells. Pediatr. Res. 40:257-262.

352. Mattsson, E., H. Van Dijk, J. Verhoef, R. Norrby, and J. Rollof. 1996 Supernatants from Staphylococcus epidermidis grown in the presence of different antibiotics induce differential release of tumor necrosis factor alpha from human monocytes. Infect. Immun. 64:4351-4355.

353. Mayer, A. M. S., and J. A. Spitzer. 1991. Continuous infusion of Escherichia coli endotoxin in vivo primes superoxide anion release in rat polymorpho- nuclear leukocytes and Kupffer cells in a time-dependent manner. Infect. Immun. 59:4590-4598.

354. Mayo, K. H., J. Haseman, E. Ilyina, and B. Gray. 1998. Designed $\beta$-sheetforming peptide 33 mers with potent human bactericidal/permeability increasing protein-like bactericidal and endotoxin neutralizing activities. Biochim. Biophys. Acta 1425:81-92.

355. McGinley, M. D., L. O. Narhi, M. J. Kelley, E. Davy, J. Robinson, M. F. Rohde, S. D. Wright, and H. S. Lichenstein. 1995. CD14: Physical properties and identification of an exposed site that is protected by lipopolysaccharide. J. Biol. Chem. 270:5213-5218.

356. Means, T. K., E. Lien, A. Yoshimura, S. Wang, D. T. Golenbock, and M. J. Fenton. 1999. The CD14 ligands lipoarabinomannan and lipopolysaccharide differ in their requirement for Toll-like receptors. J. Immunol. 163: $6748-6755$.

357. Means, T. K., S. Wang, E. Lien, A. Yoshimura, D. T. Golenbock, and M. J. Fenton. 1999. Human toll-like receptors mediate cellular activation by Mycobacterium tuberculosis. J. Immunol. 163:3920-3927.

358. Medvedev, A. E., T. Flo, R. R. Ingalls, D. T. Golenbock, G. Teti, S. N. Vogel, and T. Espevik. 1998. Involvement of CD14 and complement receptors CR3 and CR4 in nuclear factor- $\kappa \mathrm{B}$ activation and TNF production induced by lipopolysaccharide and group B streptococcal cell walls. J. Immunol. 160:4535-4542.

359. Medzhitov, R., P. Preston-Hurlburt, and C. A. Janeway, Jr. 1997. A human homologue of the Drosophila Toll protein signals activation of adaptive immunity. Nature 388:394-397.

360. Menju, M., S. Tajima, and A. Yamamoto. 1989. Expression of the apolipoprotein $\mathrm{E}$ gene in a human macrophage-like cell line, THP-1. J Biochem. (Tokyo) 106:505-510.

361. Meyer, J., F. Hinder, J. Stothert Jr, L. D. Traber, D. N. Herndon, J. T. Flynn, and D. L. Traber. 1994. Increased organ blood flow in chronic endotoxemia is reversed by nitric oxide synthase inhibition. J. Appl. Physiol. 76:2785-2793.

362. Mészáros, K., J. B. Parent, H. Gazzano-Santoro, R. Little, A. Horwitz, T. Parsons, G. Theofan, L. Grinna, J. Weickmann, P. Elsbach, J. Weiss, and P. J. Conlon. 1993. A recombinant amino terminal fragment of bactericidal/ permeability-increasing protein inhibits the induction of leukocytes responses by LPS. J. Leukoc. Biol. 54:558-563.

363. Michalek, S. M., R. N. Moore, J. R. McGhee, D. L. Rosenstreich, and S. E. Mergenhagen. 1980. The primary role of lymphoreticular cells in the mediation of host responses to bacterial endotoxim. J. Infect. Dis. 141:55-63.

364. Mistry, M. J., M. A. Clay, M. E. Kelly, M. A. Steiner, and J. A. Harmony. 1995. Apolipoprotein E restricts interleukin-dependent T lymphocyte proliferation at the G1A/G1B boundary. Cell. Immunol. 160:14-23.

365. Moore, R. N., K. J. Goodrum, and L. J. Berry. 1976. Mediation of an endotoxic effect by macrophages. J. Reticuloendothel. Soc. 19:187-197.

366. Morel, D. W., P. E. DiCorleto, and G. M. Chisolm. 1986. Modulation of endotoxin-induced endothelial cell toxicity by low density lipoprotein. Lab. Investig. 55:419-426.

367. Morrison, D. C., and L. Leive. 1975. Fractions of lipopolysaccharide from Escherichia coli O111:B4 prepared by two extraction procedures. J. Biol. Chem. 250:2911-2919.

368. Mózes, T., F. J. Zijlstra, and J. P. C. Heiligers. 1992. Interactions between platelet activating factor and eicosanoids during endotoxic shock in anaesthetized pigs. Mediat. Inflamm. 1:183-190.

369. Mózes, T., F. J. Zijlstra, J. P. C. Heiligers, C. J. A. M. Tak, S. Ben Efraim, I. L. Bonta, and P. R. Saxena. 1991. Sequential release of tumour necrosis factor, platelet activating factor and eicosanoids during endotoxin shock in anaesthetized pigs; protective effects of indomethacin. Br. J. Pharmacol. 104:691-699.

370. Mulligan, M. S., C. W. Smith, D. C. Anderson, R. F. Todd III, M. Miyasaka, T. Tamatami, T. B. Issekutz, and P. A. Ward. 1993. Role of leukocyte adhesion molecules in complement-induced lung injury. J. Immunol. 150: 2401-2406.

371. Munck, A., P. M. Guyre, and N. J. Holbrook. 1984. Physiological functions of glucocorticoids in stress and their relation to pharmacological actions. Endocr. Rev. 5:25-44.

372. Munford, R. S., and J. M. Dietschy. 1985. Effects of specific antibodies, hormones, and lipoproteins on bacterial lipopolysaccharides injected into the rat. J. Infect. Dis. 152:177-184.

373. Munford, R. S., and C. L. Hall. 1989. Purification of acyloxyacyl hydrolase, a leukocyte enzyme that removes secondary acyl chains from bacterial lipopolysaccharides. J. Biol. Chem. 264:15613-15619.

374. Munford, R. S., C. L. Hall, and J. M. Dietschy. 1981. Binding of Salmonella typhimurium lipopolysaccharides to rat high-density lipoproteins. Infect. Immun. 34:835-843.

375. Munford, R. S., C. L. Hall, J. M. Lipton, and J. M. Dietschy. 1982. Biological activity, lipoprotein-binding behavior, and in vivo disposition of extracted and native forms of Salmonella typhimurium lipopolysaccharides. J. Clin. Investig. 70:877-888.

376. Muzio, M., D. Bosisio, N. Polentarutti, G. D'amico, A. Stoppacciaro, R. Mancinelli, C. van't Veer, G. Penton-Rol, L. P. Ruco, P. Allavena, and A. Mantovani. 2000. Differential expression and regulation of toll-like recep- 
tors (TLR) in human leukocytes: selective expression of TLR3 in dendritic cells. J. Immunol. 164:5998-6004.

377. Muzio, M., N. Polentarutti, D. Bosisio, P. P. Manoj Kumar, and A. Mantovani. 2000. Toll-like receptor family and signalling pathway. Biochem. Soc. Trans. 28:563-566.

378. Müller-Loennies, S., U. Zähringer, U. Seydel, S. Kusumoto, A. J. Ulmer, and E. T. Rietschel. 1998. What we know and don't know about the chemical and physical structure of lipopolysaccharide in relation to biological activity. Prog. Clin. Biol. Res. 397:51-72.

379. Nagai, Y., S. Akashi, M. Nagafuku, M. Ogata, Y. Iwakura, S. Akira, T. Kitamura, A. Kosugi, M. Kimoto, and K. Miyake. 2002. Essential role of MD-2 in LPS responsiveness and TLR4 distribution. Nat. Immunol. 3:667672.

380. Nagai, Y., R. Shimazu, H. Ogata, S. Akashi, K. Sudo, H. Yamasaki, S Hayashi, Y. Iwakura, M. Kimoto, and K. Miyake. 2002. Requirement for MD-1 in cell surface expression of RP105/CD180 and B- cell responsiveness to lipopolysaccharide. Blood 99:1699-1705.

381. Nagaoka, I., Y. Tsutsumi-Ishii, S. Yomogida, and T. Yamashita. 1997. Isolation of cDNA encoding guinea pig neutrophil cationic antibacterial polypeptide of $11 \mathrm{kDa}$ (CAP11) and evaluation of CAP11 mRNA expression during neutrophil maturation. J. Biol. Chem. 272:22742-22750.

382. Naito, M., H. Suzuki, T. Mori, A. Matsumoto, T. Kodama, and K. Takahashi. 1992. Coexpression of type I and type II human macrophage scavenger receptors in macrophages of various organs and foam cells in atherosclerotic lesions. Am. J. Pathol. 141:591-599.

383. Nanbo, A., H. Nishimura, T. Muta, and S. Nagasawa. 1999. Lipopolysaccharide stimulates HepG2 human hepatoma cells in the presence of lipopolysaccharide-binding protein via CD14. Eur. J. Biochem. 260:183-191.

384. Navarre, W. W., and O. Schneewind. 1999. Surface proteins of grampositive bacteria and mechanisms of their targeting to the cell wall envelope. Microbiol. Mol. Biol. Rev. 63:174-229.

385. Netea, M. G., N. de Bont, P. N. Demacker, B. J. Kullberg, L. E. Jacobs, T. J. Verver-Jansen, A. F. Stalenhoef, and J. W. van der Meer. 1998. Lipoprotein(a) inhibits lipopolysaccharide-induced tumor necrosis factor $\alpha$ production by human mononuclear cells. Infect. Immun. 66:2365-2367.

386. Netea, M. G., P. N. Demacker, B. J. Kullberg, L. E. Jacobs, T. J. VerverJansen, O. C. Boerman, A. F. Stalenhoef, and J. W. van der Meer. 1998. Bacterial lipopolysaccharide binds and stimulates cytokine-producing cells before neutralization by endogenous lipoproteins can occur. Cytokine 10 766-772.

387. Netea, M. G., P. N. M. Demacker, B. J. Kullberg, O. C. Boerman, I Verschueren, A. F. H. Stalenhoef, and J. W. M. Van Der Meer. 1996 Low-density lipoprotein receptor-deficient mice are protected against lethal endotoxemia and severe Gram-negative infections. J. Clin. Investig. 97: 1366-1372.

388. Newman, S. L, S. Chaturverdi, and B. S. Klein. 1995. The WI- antigen of Blastomyces dermatitidis yeasts mediates binding to human macrophage CD11b/CD18 (CR3) and CD14. J. Immunol. 154:753-761.

389. Niho, Y., H. Niiro, Y. Tanaka, H. Nakashima, and T. Otsuka. 1998. Role of IL-10 in the crossregulation of prostaglandins and cytokines in monocytes. Acta Haematol. 99:165-170.

390. Nomura, F., S. Akashi, Y. Sakao, S. Sato, T. Kawai, M. Matsumoto, K Nakanishi, M. Kimoto, K. Miyake, K. Takeda, and S. Akira. 2000. Cutting edge: endotoxin tolerance in mouse peritoneal macrophages correlates with down-regulation of surface Toll-like receptor 4 expression. J. Immunol. 164:3476-3479.

391. Nonogaki, K., A. H. Moser, K. R. Feingold, and C. Grunfeld. 1994. Alphaadrenergic receptors mediate the hypertriglyceridemia induced by endotoxin, but not tumor necrosis factor, in rats. Endocrinology 135:2644-2650.

392. Nonogaki, K., A. H. Moser, X. M. Pan, I. Staprans, C. Grunfeld, and K. R. Feingold. 1995. Lipoteichoic acid stimulates lipolysis and hepatic triglyceride secretion in rats in vivo. J. Lipid Res. 36:1987-1995.

393. Reference deleted.

394. Ogata, H., I. Su, K. Miyake, Y. Nagai, S. Akashi, I. Mecklenbrauker, K. Rajewsky, M. Kimoto, and A. Tarakhovsky. 2000. The toll-like receptor protein RP105 regulates lipopolysaccharide signaling in B cells. J. Exp. Med. 192:23-29.

395. Ogata, M., M. F. Fletcher, M. Kloczewiak, P. M. Loiselle, E. M. Zanzot, M. W. Vermeulen, and H. S. Warren. 1997. Effect of anticoagulants on binding and neutralization of lipopolysaccharide by the peptide immunoglobulin conjugate CAP18 $106-138^{-i m m u n o g l o b u l i n ~} \mathrm{G}$ in whole blood. Infect. Immun. 65:2160-2167.

396. Ohashi, K., V. Burkart, S. Flohe, and H. Kolb. 2000. Heat shock protein 60 is a putative endogenous ligand of the toll-like receptor-4 complex. J. Immunol. 164:558-561.

397. Ohno, N., and D. C. Morrison. 1989. Lipopolysaccharide interaction with lysozyme. J. Biol. Chem. 264:4434-4441.

398. Ohno, N., and D. C. Morrison. 1989. Lipopolysaccharide interactions with lysozyme differentially affect lipopolysaccharide immunostimulatory activity. Eur. J. Biochem. 186:629-636.

399. Okano, Y., M. Macy, A. D. Cardin, and J. A. Harmony. 1985. Suppression of lymphocyte activation by plasma lipoproteins: modulation by cell number and type. Exp. Cell Biol. 53:199-212.

400. Olynyk, J. K., G. M. Matuschak, A. J. Lechner, R. S. Britton, T. L. Tredway, R. O'Neill, and B. R. Bacon. 1994. Differential production of TNF by Kupffer cells after phagocytosis of E. coli and C. albicans. Am. J. Physiol. 267:G213-G219.

400a.O'Neill, L. 2000. The Toll/interleukin-1 receptor domain: a molecular switch for inflammation and host defence. Biochem. Soc. Trans. 28:557563.

401. Ooi, C. E., J. Weiss, M. E. Doerfler, and P. Elsbach. 1991. Endotoxinneutralizing properties of the $25 \mathrm{kD}$ N-terminal fragment and a newly isolated $30 \mathrm{kD}$ C-terminal fragment of the $55-60 \mathrm{kD}$ bactericidal/permeability-increasing protein of human neutrophils. J. Exp. Med. 174:649-655.

402. Ooi, C. E., J. Weiss, P. Elsbach, B. Frangione, and B. Mannion. 1987. A $25-\mathrm{kDa} \mathrm{NH}_{2}$-terminal fragment carries all the antibacterial activities of the human neutrophil $60-\mathrm{kDa}$ bactericidal/permeability-increasing protein. J. Biol. Chem. 262:14891-14894.

403. Opal, S. M., and J. Cohen. 1999. Clinical gram-positive sepsis: does it fundamentally differ from gram-negative bacterial sepsis? Crit. Care Med. 27:1608-1616.

404. Opal, S. M., C. J. Fisher, Jr., J. F. Dhainaut, J. L. Vincent, R. Brase, S. F. Lowry, J. C. Sadoff, G. J. Slotman, H. Levy, R. A. Balk, M. P. Shelly, J. P. Pribble, J. F. LaBrecque, J. Lookabaugh, H. Donovan, H. Dubin, R. Baughman, J. Norman, E. DeMaria, K. Matzel, E. Abraham, M. Seneff, and The Interleukin-1 Receptor Antagonist Sepsis Investigator Group. 1997. Confirmatory interleukin-1 receptor antagonist trial in severe sepsis: a phase III, randomized, double-blind, placebo-controlled, multicenter trial. Crit. Care Med. 25:1115-1124.

405. Opitz, B., N. W. Schroder, I. Spreitzer, K. S. Michelsen, C. J. Kirschning, W. Hallatschek, U. Zahringer, T. Hartung, U. B. Gobel, and R. R. Schumann. 2001. Toll-like receptor-2 mediates Treponema glycolipid and lipoteichoic acid-induced NF-кB translocation. J. Biol. Chem. 276:2204122047.

406. Ou, J., T. M. Carlos, S. C. Watkins, J. E. Saavedra, L. K. Keefer, Y. M. Kim, B. G. Harbrecht, and T. R. Billiar. 1997. Differential effects of nonselective nitric oxide synthase (NOS) and selective inducible NOS inhibition on hepatic necrosis, apoptosis, ICAM-1 expression, and neutrophil accumulation during endotoxemia. Nitric Oxide 1:404-416.

407. Ozinsky, A., D. M. Underhill, J. D. Fontenot, A. M. Hajjar, K. D. Smith, C. B. Wilson, L. Schroeder, and A. Aderem. 2000. The repertoire for pattern recognition of pathogens by the innate immune system is defined by cooperation between toll-like receptors. Proc. Natl. Acad. Sci. USA 97:1376613771.

408. Pajkrt, D., J. E. Doran, F. Koster, P. G. Lerch, B. Arnet, T. Van Der Poll, J. W. Ten Cate, and S. J. H. Van Deventer. 1996. Antiinflammatory effects of reconstituted high-density lipoprotein during human endotoxemia. J. Exp. Med. 184:1601-1608.

409. Pajkrt, D., P. G. Lerch, T. Van Der Poll, M. Levi, M. Illi, J. E. Doran, B. Arnet, A. Van Den Ende, J. W. Ten Cate, and S. J. H. Van Deventer. 1997 Differential effects of reconstituted high-density lipoprotein on coagulation, fibrinolysis, and platelet activation during human endotoxemia. Thromb. Haemostasis 77:303-307.

410. Palkama, T. 1991. Induction of interleukin-1 production by ligands binding to the scavenger receptor in human monocytes and the THP-1 cell line. Immunology 74:432-438.

411. Palkama, T., M. L. Majuri, P. Mattila, M. Hurme, and R. Renkonen. 1993. Regulation of endothelial adhesion molecules by ligands binding to the scavenger receptor. Clin. Exp. Immunol. 92:353-360.

412. Parent, J. B. 1990. Membrane receptors on rat hepatocytes for the inner core region of bacterial lipopolysaccharide. J. Biol. Chem. 265:3455-3461.

413. Parillo, J. E. 1993. Pathogenetic mechanisms of septic shock. N. Engl. J. Med. 328:1471-1477.

414. Park, C. T., and S. D. Wright. 1996. Plasma lipopolysaccharide-binding protein is found associated with a particle containing apolipoprotein A-I, phospholipid, and factor H-related proteins. J. Biol. Chem. 271:1805418060 .

415. Parker, T. S., D. M. Levine, J. C. C. Chang, J. Laxer, C. C. Coffin, and A. L. Rubin. 1995. Reconstituted high-density lipoprotein neutralizes gram-negative bacterial lipopolysaccharides in human whole blood. Infect. Immun. 63:253-258.

416. Peiser, L., P. J. Gough, T. Kodama, and S. Gordon. 2000. Macrophage class A scavenger receptor-mediated phagocytosis of Escherichia coli: role of cell heterogeneity, microbial strain, and culture conditions in vitro. Infect. Immun. 68:1953-1963.

417. Pepe, M. G., and L. K. Curtiss. 1986. Apolipoprotein E is a biologically active constituent of the normal immunoregulatory lipoprotein, LDL-In. J. Immunol. 136:3716-3723.

418. Pereira, H. A. 1995. CAP37, a neutrophil-derived multifunctional inflammatory mediator. J. Leukoc. Biol. 57:805-812.

419. Pereira, H. A., P. Moore, and P. Grammas. 1996. CAP37, a neutrophil granule-derived protein stimulates protein kinase $\mathrm{C}$ activity in endothelial cells. J. Leukoc. Biol. 60:415-422. 
420. Perera, P. Y., T. N. Mayadas, O. Takeuchi, S. Akira, M. Zaks-Zilberman S. M. Goyert, and S. N. Vogel. 2001. CD11b/CD18 acts in concert with CD14 and toll-like receptor (TLR) 4 to elicit full lipopolysaccharide and taxol-inducible gene expression. J Immunol. 166:574-581.

421. Peterson, P. K., G. Gekker, S. Hu, W. S. Sheng, W. R. Anderson, R. J. Ulevitch, P. S. Tobias, K. V. Gustafson, T. W. Molitor, and C. C. Chao 1995. CD14 receptor-mediated uptake of nonopsonized Mycobacterium tuberculosis by human microglia. Infect. Immun. 63:1598-1602.

422. Pfeffer, K., T. Matsuyama, T. M. Kündig, A. Wakeham, K. Kishihara, A Shahinian, K. Wiegmann, P. S. Ohashi, M. Krönke, and T. W. Mak. 1993. Mice deficient for the $55 \mathrm{kd}$ tumor necrosis factor receptor are resistant to endotoxic shock, yet succumb to L. monocytogenes infection. Cell 73:457467.

423. Phillips, M. J., and P. Satir. 1988. The cells. The hepatocyte: organization p. 9-10. In I. M. Arias, W. B. Jakoby, H. Popper, D. Schachter, and D. A. Shafritz (ed.), The liver: biology and pathobiology. Raven Press, New York, N.Y.

424. Pieters, J. 2001. Evasion of host cell defense mechanisms by pathogenic bacteria. Curr. Opin. Immunol. 13:37-44.

425. Poelstra, K., W. W. Bakker, P. A. Klok, J. A. Kamps, M. J. Hardonk, and D. K. Meijer. 1997. Dephosphorylation of endotoxin by alkaline phosphatase in vivo. Am. J. Pathol. 151:1163-1169.

426. Pohlman, T. H., R. S. Munford, and J. M. Harlan. 1987. Deacylated lipopolysaccharide inhibits neutrophil adherence to endothelium induced by lipopolysaccharide in vitro. J. Exp. Med. 165:1393-1402.

427. Pollack, M., C. A. Ohl, D. T. Golenbock, F. Di Padova, L. M. Wahl, N. L. Koles, G. Guelde, and B. G. Monks. 1997. Dual effects of LPS antibodies on cellular uptake of LPS and LPS-induced proinflammatory functions. J. Immunol. 159:3519-3530.

428. Poltorak, A., X. He, I. Smirnova, M. Y. Liu, C. V. Huffel, X. Du, D. Birdwell, E. Alejos, M. Silva, C. Galanos, M. Freudenberg, P. Ricciardi-Castagnoli, B. Layton, and B. Beutler. 1998. Defective LPS signaling in $\mathrm{C} 3 \mathrm{H} / \mathrm{HeJ}$ and C57BL/10ScCr mice: mutations in Tlr4 gene. Science 282:2085-2088.

429. Poltorak, A., P. Ricciardi-Castagnoli, S. Citterio, and B. Beutler. 2000 Physical contact between lipopolysaccharide and toll-like receptor 4 re vealed by genetic complementation. Proc. Natl. Acad. Sci. USA 97:21632167

430. Poltorak, A., I. Smirnova, X. He, M. Y. Liu, C. Van Huffel, O. McNally, D. Birdwell, E. Alejos, M. Silva, X. Du, P. Thompson, E. K. Chan, J. Ledesma, B. Roe, S. Clifton, S. N. Vogel, and B. Beutler. 1998. Genetic and physical mapping of the Lps locus: identification of the toll-4 receptor as a candidate gene in the critical region. Blood Cells Mol. Dis. 24:340-355.

431. Poussin, C., M. Foti, J. L. Carpentier, and J. Pugin. 1998. CD14-dependent endotoxin internalization via a macropinocytic pathway. J. Biol. Chem. 273:20285-20291.

432. Praaning-Van Dalen, D. P., A. Brouwer, and D. L. Knook. 1981. Clearance capacity of rat liver Kupffer, endothelial, and parenchymal cells. Gastroenterology 81:1036-1044.

433. Pugin, J., C. C. Schürer-Maly, D. J. Leturcq, A. M. Moriarty, R. J. Ulevitch, and P. S. Tobias. 1993. Lipopolysaccharide activation of human endothelial and epithelial cells is mediated by lipopolysaccharide-binding protein and soluble CD14. Proc. Natl. Acad. Sci. USA 90:2744-2748.

434. Püschel, G. P., U. Hespeling, M. Oppermann, and P. Dieter. 1993. Increase in prostanoid formation in rat liver macrophages (Kupffer cells) by human anaphylatoxin C3a. Hepatology 18:1516-1521.

435. Quakyi, E. K., H. D. Hochstein, and C. M. Tsai. 1997. Modulation of the biological activities of meningococcal endotoxins by association with outer membrane proteins is not inevitably linked to toxicity. Infect. Immun. 65: 1972-1979.

436. Quezado, Z. M. N., W. D. Hoffman, J. A. Winkelstein, I. Yatsiv, C. A. Koev, L. C. Cork, R. J. Elin, P. Q. Eichacker, and C. Natanson. 1994. The third component of complement protects against Escherichia coli endotoxininduced shock and multiple organ failure. J. Exp. Med. 179:569-578.

437. Quezado, Z. M. N., C. Natanson, S. M. Banks, D. W. Alling, C. A. Koev, R. L. Danner, R. J. Elin, J. M. Hosseini, T. S. Parker, D. M. Levine, A. L. Rubin, and W. D. Hoffman. 1995. Therapeutic trial of reconstituted human high-density lipoprotein in a canine model of Gram-negative septic shock J. Pharmacol. Exp. Ther. 272:604-611.

438. Qureshi, N., J. P. Honovich, H. Hara, R. J. Cotter, and K. Takayama. 1988 Location of fatty acids in lipid A obtained from lipopolysaccharide of Rhodopseudomonas sphaeroides ATCC 17023. J. Biol. Chem. 263:55025504

439. Qureshi, S. T., P. Gros, and D. Malo. 1999. Host resistance to infection: genetic control of lipopolysaccharide responsiveness by TOLL-like receptor genes. Trends Genet. 15:291-294.

440. Qureshi, S. T., P. Gros, and D. Malo. 1999. The Lps locus: genetic regulation of host responses to bacterial lipopolysaccharide. Inflamm. Res. 48:613-620

441. Qureshi, S. T., L. Lariviere, G. Leveque, S. Clermont, K. J. Moore, P. Gros, and D. Malo. 1999. Endotoxin-tolerant mice have mutations in Toll-like receptor 4 (TLR4). J. Exp. Med. 189:615-625.
442. Rackow, E. C., and M. E. Astiz. 1991. Pathophysiology and treatment of septic shock. JAMA 266:548-554

443. Raetz, C. R. H. 1990. Biochemistry of endotoxins. Annu. Rev. Biochem. 59:129-170.

444. Ramadori, G., K. H. Meyer zum Buschenfelde, P. S. Tobias, J. C. Mathison, and R. J. Ulevitch. 1990. Biosynthesis of lipopolysaccharide-binding protein in rabbit hepatocytes. Pathobiology 58:89-94.

445. Read, T. E., C. Grunfeld, Z. Kumwenda, M. C. Calhoun, J. P. Kane, K. R. Feingold, and J. H. Rapp. 1995. Triglyceride-rich lipoproteins improve survival when given after endotoxin in rats. Surgery 117:62-67.

446. Read, T. E., C. Grunfeld, Z. L. Kumwenda, M. C. Calhoun, J. P. Kane, K. R. Feingold, and J. H. Rapp. 1995. Triglyceride-rich lipoproteins prevent septic death in rats. J. Exp. Med. 182:267-272.

447. Read, T. E., H. W. Harris, C. Grunfeld, K. R. Feingold, M. C. Calhoun, J. P. Kane, and J. H. Rapp. 1993. Chylomicrons enhance endotoxin excretion in bile. Infect. Immun. 61:3496-3502.

448. Rensen, P. C., M. C. Jong, L. C. van Vark, H. van der Boom, W. L. Hendriks, T. J. van Berkel, E. A. Biessen, and L. M. Havekes. 2000. Apolipoprotein $\mathrm{E}$ is resistant to intracellular degradation in vitro and in vivo. Evidence for retroendocytosis. J. Biol. Chem. 275:8564-8571.

449. Rensen, P. C. N., M. Van Oosten, E. Van De Bilt, M. Van Eck, J. Kuiper, and T. Van Berkel. 1997. Human recombinant apolipoprotein E redirect lipopolysaccharide from Kupffer cells to liver parenchymal cells in rats in vivo. J. Clin. Investig. 99:2438-2445.

450. Repo, H., R. Renkonen, I. M. Helander, and M. Leirisalo-Repo. 1994. Alkali-treated LPS of Yersinia enterocolitica does not induce expression of E-selectin, ICAM-1 or VCAM-1 on endothelial cells but may mediate antibody- and complement-dependent cell injury. Scand. J. Immunol. 39: 241-248.

451. Ried, C., C. Wahl, T. Miethke, G. Wellnhofer, C. Landgraf, J. SchneiderMergener, and A. Hoess. 1996. High affinity endotoxin-binding and neutralizing peptides based on the crystal structure of recombinant Limulus anti-lipopolysaccharide factor. J. Biol. Chem. 271:28120-28127.

452. Rieder, H., K. H. Meyer zum Büschenfelde, and G. Ramadori. 1992. Functional spectrum of sinusoidal endothelial liver cells. J. Hepatol. 15:237-250.

453. Rietschel, E. T., and H. Brade. 1992. Bacterial endotoxins. Sci. Am. 267: 156-163.

454. Rietschel, E. T., T. Kirikae, F. U. Schade, U. Mamat, G. Schmidt, H. Loppnow, A. J. Ulmer, U. Zähringer, U. Seydel, F. Di Padova, M. Schreier, and H. Brade. 1994. Bacterial endotoxin: molecular relationships of structure to activity and function. FASEB J. 8:217-225.

455. Roberts, I. S. 1996. The biochemistry and genetics of capsular polysaccharide production in bacteria. Annu. Rev. Microbiol. 50:285-315.

456. Roitt, I. M. 1994. Immunity to infection, p. 243-271. In I. M. Roitt (ed.), Essential immunology. Blackwell Scientific Publications, Oxford, United Kingdom.

457. Roitt, I. M. 1994. Innate immunity, p. 3-21. In I. M. Roitt (ed.), Essential immunology. Blackwell Scientific Publications, Oxford, United Kingdom.

458. Roland, C. R., J. A. Goss, M. J. Mangino, D. Hafenrichter, and M. W. Flye. 1994. Autoregulation by eicosanoids of human Kupffer cell secretory products. Ann. Surg. 219:389-399.

459. Rose, J. R., M. A. Mullarkey, W. J. Christ, L. D. Hawkins, M. Lynn, Y. Kishi, K. M. Wasan, K. Peteherych, and D. P. Rossignol. 2000. Consequences of interaction of a lipophilic endotoxin antagonist with plasma lipoproteins. Antimicrob. Agents Chemother. 44:504-510.

460. Rose, R. K., and S. D. Hogg. 1995. Competitive binding of calcium and magnesium to streptococcal lipoteichoic acid. Biochim. Biophys. Acta 1245: 94-98.

461. Roselaar, S. E., and A. Daugherty. 1997. Lipopolysaccharide decreases scavenger receptor mRNA in vivo. J. Interferon Cytokine Res. 17:573-579.

462 Rosenberger, C. M. M. G. Scott, M. R. Gold, R. E. Hancock, and B. B. Finlay. 2000. Salmonella typhimurium infection and lipopolysaccharide stimulation induce similar changes in macrophage gene expression. J. Immunol. 164:5894-5904.

463. Rosenfeld, M. E., S. Butler, V. A. Ord, B. A. Lipton, C. A. Dyer, L. K. Curtiss, W. Palinski, and J. L. Witztum. 1993. Abundant expression of apoprotein $\mathrm{E}$ by macrophages in human and rabbit atherosclerotic lesions. Arterioscler. Thromb. 13:1382-1389.

464. Roth, R. I., F. C. Levin, and J. Levin. 1993. Distribution of bacterial endotoxin in human and rabbit blood and effects of stroma-free hemoglobin. Infect. Immun. 61:3209-3215.

465. Ruhland, G. J., and F. Fiedler. 1990. Occurrence and structure of lipotei choic acids in the genus Staphylococcus. Arch. Microbiol. 154:375-379.

466. Ruiter, D. J., J. Van Der Meulen, A. Brouwer, M. J. R. Hummel, B. J. Mauw, J. C. M. Van Der Ploeg, and E. Wisse. 1981. Uptake by liver cells of endotoxin following its intravenous injection. Lab. Investig. 45:38-45.

467. Sano, H., H. Chiba, D. Iwaki, H. Sohma, D. R. Voelker, and Y. Kuroki. 2000. Surfactant proteins A and D bind CD14 by different mechanisms. J. Biol. Chem. 275:22442-22451.

468. Schimke, J., J. Mathison, J. Morgiewicz, and R. J. Ulevitch. 1998. Anti$\mathrm{CD} 14 \mathrm{mAb}$ treatment provides therapeutic benefit after in vivo exposure to endotoxin. Proc. Natl. Acad. Sci. USA 95:13875-13880. 
469. Schnare, M., G. M. Barton, A. C. Holt, K. Takeda, S. Akira, and R Medzhitov. 2001. Toll-like receptors control activation of adaptive immune responses. Nat. Immunol. 2:947-950.

470. Scholl, R. A., C. H. Lang, and G. J. Bagby. 1984. Hypertriglyceridemia and its relation to tissue lipoprotein lipase activity in endotoxemic, Escherichia coli bacteremic, and polymicrobial septic rats. J. Surg. Res 37:394-401.

471. Schroder, N. W., B. Opitz, N. Lamping, K. S. Michelsen, U. Zahringer, U. B. Gobel, and R. R. Schumann. 2000. Involvement of lipopolysaccharide binding protein, CD14, and Toll-like receptors in the initiation of innate immune responses by Treponema glycolipids. J. Immunol. 165:2683-2693.

472. Schromm, A. B., K. Brandenburg, H. Loppnow, U. Zahringer, E. T. Rietschel, S. F. Carroll, M. H. Koch, S. Kusumoto, and U. Seydel. 1998. The charge of endotoxin molecules influences their conformation and IL-6inducing capacity. J. Immunol. 161:5464-5471.

473. Schumann, R. R., C. J. Kirschning, A. Unbehaun, H. P. Aberle, H. P. Knope, N. Lamping, R. J. Ulevitch, and F. Herrmann. 1996. The lipopolysaccharide-binding protein is a secretory class 1 acute- phase protein whose gene is transcriptionally activated by APRF/STAT/3 and other cytokineinducible nuclear proteins. Mol. Cell. Biol. 16:3490-3503.

474. Schumann, R. R., N. Lamping, C. Kirschning, H. P. Knopf, A. Hoess, and F. Herrmann. 1994. Lipopolysaccharide binding protein: its role and therapeutical potential in inflammation and sepsis. Biochem. Soc. Trans. 22: 80-82.

475. Schumann, R. R., S. R. Leong, G. W. Flaggs, P. W. Gray, S. D. Wright, J. C Mathison, P. S. Tobias, and R. J. Ulevitch. 1990. Structure and function of lipopolysaccharide binding protein. Science 249:1429-1431.

476. Schumann, R. R., and J. Zweigner. 1999. A novel acute-phase marker: lipopolysaccharide binding protein (LBP). Clin. Chem. Lab. Med. 37:271274.

477. Schütt, C., T. Schilling, U. Grunwald, W. Schönfeld, and C. Krüger. 1992 Endotoxin-neutralizing capacity of soluble CD14. Res. Immunol. 143:7178.

478. Schwandner, R., R. Dziarski, H. Wesche, M. Rothe, and C. J. Kirschning. 1999. Peptidoglycan- and lipoteichoic acid-induced cell activation is mediated by toll-like receptor 2. J. Biol. Chem. 274:17406-17409.

479. Scott, M. G., M. R. Gold, and R. E. Hancock. 1999. Interaction of cationic peptides with lipoteichoic acid and gram-positive bacteria. Infect. Immun. 67:6445-6453.

480. Scott, M. G., A. C. E. Vreugdenhil, W. A. Buurman, R. E. W. Hancock, and M. Gold. 2000. Cationic antimicrobial peptides block the binding of lipopolysaccharide (LPS) to LPS binding protein. J. Immunol. 164:549-553.

481. Seki, E., H. Tsutsui, H. Nakano, N. Tsuji, K. Hoshino, O. Adachi, K Adachi, S. Futatsugi, K. Kuida, O. Takeuchi, H. Okamura, J. Fujimoto, S. Akira, and K. Nakanishi. 2001. Lipopolysaccharide-induced IL-18 secretion from murine Kupffer cells independently of myeloid differentiation factor 88 that is critically involved in induction of production of IL-12 and IL-1beta. J. Immunol. 166:2651-2657.

482. Seki, S., Y. Habu, T. Kawamura, K. Takeda, H. Dobashi, T. Ohkawa, and H. Hiraide. 2000. The liver as a crucial organ in the first line of host defense: the roles of Kupffer cells, natural killer (NK) cells and NK1.1 $\mathrm{Ag}^{+} \mathrm{T}$ cells in $\mathrm{T}$ helper 1 immune responses. Immunol. Rev. 174:35-46.

483. Sester, D. P., K. J. Stacey, M. J. Sweet, S. J. Beasley, S. L. Cronau, and D. A Hume. 1999. The actions of bacterial DNA on murine macrophages. J. Leukoc. Biol. 66:542-548.

484. Setoguchi, M., N. Nasu, S. Yoshida, Y. Higuchi, S. Akizuki, and S. Yamamoto. 1989. Mouse and human CD14 (myeloid cell-specific leucinerich glycoprotein) primary structure deduced from cDNA clones. Biochim. Biophys. Acta 1008:213-222.

485. Shi, J., H. Fujieda, Y. Kokubo, and K. Wake. 1996. Apoptosis of neutrophils and their elimination by Kupffer cells in rat liver. Hepatology 24:1256-1263.

486. Shimauchi, Y., M. Tanaka, M. Yoshitake, M. Shimada, K. Sato, R. Kuro matsu, S. Tanaka, R. Kumashiro, S. Sakisaka, and K. Tanikawa. 1993. Functional differences between rat Kupffer cells and splenic macrophages, p. 198-200. In D. L. Knook and E. Wisse (ed.), Cells of the hepatic sinusoid. The Kupffer Cell Foundation, Leiden, The Netherlands.

487. Shimazu, R., S. Akashi, H. Ogata, Y. Nagai, K. Fukudome, K. Miyake, and M. Kimoto. 1999. MD-2, a molecule that confers lipopolysaccharide responsiveness on Toll-like receptor 4. J. Exp. Med. 189:1777-1782.

488. Shnyra, A., K. Hultenby, and A. A. Lindberg. 1993. Role of the physical state of Salmonella lipopolysaccharide in expression of biological and endotoxic properties. Infect. Immun. 61:5351-5360.

489. Shnyra, A., and A. A. Lindberg. 1995. Scavenger receptor pathway for lipopolysaccharide binding to Kupffer and endothelial liver cells in vitro. Infect. Immun. 63:865-873.

490. Shore, B., and V. Shore. 1974. An apolipoprotein preferentially enriched in cholesteryl ester-rich very low density lipoproteins. Biochem. Biophys. Res. Commun. 58:1-7.

491. Silverstein, R., J. G. Wood, Q. Xue, M. Norimatsu, D. L. Horn, and D. C. Morrison. 2000. Differential host inflammatory responses to viable versus antibiotic-killed bacteria in experimental microbial sepsis. Infect. Immun. 68:2301-2308.
492. Spijkstra, J. J., and A. R. Girbes. 2000. The continuing story of corticosteroids in the treatment of septic shock. Intensive Care Med. 26:496-500.

493. Spitzer, J. A., and R. A. Pittner. 1993. Continuous non-lethal endotoxemia primes Kupffer and parenchymal liver cells for enhanced nitric oxide production in response to a subsequent endotoxin or TNF challenge in vitro, $p$. 85-87. In D. L. Knook and E. Wisse (ed.), Cells of the hepatic sinusoid. Kupffer Cell Foundation, Leiden, The Netherlands.

494. Spitzer, J. H., A. Visintin, A. Mazzoni, M. N. Kennedy, and D. M. Segal. 2002. Toll-like receptor 1 inhibits Toll-like receptor 4 signaling in endothelial cells. Eur. J. Immunol. 32:1182-1187.

495. Sriskandan, S., and J. Cohen. 1999. Gram-positive sepsis. Mechanisms and differences from gram-negative sepsis. Infect. Dis. Clin. North Am. 13:397412.

496. Srivastava, R. A., N. Bhasin, and N. Srivastava. 1996. Apolipoprotein E gene expression in various tissues of mouse and regulation by estrogen. Biochem. Mol. Biol. Int. 38:91-101.

497. Starnes, H. F., Jr., R. S. Warren, M. Jeevanandam, J. L. Gabrilove, W. Larchian, H. F. Oettgen, and M. F. Brennan. 1988. Tumor necrosis factor and the acute metabolic response to tissue injury in man. J. Clin. Investig. 82:1321-1325.

498. Steel, D., and A. S. Whitehead. 1994. The major acute phase reactants: C-reactive protein, serum amyloid P component and serum amyloid A protein. Immunol. Today 15:81-88.

499. Stefanova, I., V. Horejsi, I. J. Ansotegui, W. Knapp, and H. Stockinger. 1991. GPI-anchored cell-surface molecules complexed to protein tyrosine kinases. Science 254:1016-1019.

500. Steinemann, S., R. J. Ulevitch, and N. Mackman. 1994. Role of the lipopolysaccharide (LPS)-binding protein/CD14 pathway in LPS induction of tissue factor expression in monocytic cells. Arterioscler. Thromb. 14:12021209.

501. Stelter, F., M. Bernheiden, R. Menzel, R. S. Jack, S. Witt, X. Fan, M. Pfister, and C. Schütt. 1997. Mutation of amino acids 39-44 of human CD14 abrogates binding of lipopolysaccharide and Escherichia coli. Eur. J. Biochem. 243:100-109.

502. Stelter, F., H. Loppnow, R. Menzel, U. Grunwald, M. Bernheiden, R. S. Jack, A. J. Ulmer, and C. Schutt. 1999. Differential impact of substitution of amino acids 9-13 and 91-101 of human CD14 on soluble CD14-dependent activation of cells by lipopolysaccharide. J. Immunol. 163:6035-6044.

503. Stelter, F., S. Witt, B. Furll, R. S. Jack, T. Hartung, and C. Schutt. 1998 Different efficacy of soluble CD14 treatment in high-and low-dose LPS models. Eur. J. Clin. Investig. 28:205-213.

504. Strittmatter, W., and C. Galanos. 1987. Characterisation of protein coextracted together with LPS in Escherichia coli, Salmonella minnesota and Yersinia enterocolitica. Microb. Pathog. 2:29-36.

505. Su, G. L., K. Dorko, S. C. Strom, A. K. Nussler, and S. C. Wang. 1999. CD14 expression and production by human hepatocytes. J. Hepatol. 31: 435-442.

506. Su, G. L., P. D. Freeswick, D. A. Geller, Q. Wang, R. A. Shapiro, Y. H. Wan, T. R. Billiar, D. J. Tweardy, R. L. Simmons, and S. C. Wang. 1994. Molecular cloning, characterization, and tissue distribution of rat lipopolysaccharide binding protein: evidence for extrahepatic expression. J. Immunol. 153:743-752

507. Sugawara, S., A. Sugiyama, E. Nemoto, H. Rikiishi, and H. Takada. 1998. Heterogeneous expression and release of CD14 by human gingival fibroblasts: characterization and CD14-mediated interleukin- 8 secretion in response to lipopolysaccharide. Infect. Immun. 66:3043-3049.

508. Sultzer, B. M., J. Bandekar, R. Castagna, and K. Abu-Lawi. 1992. Immunomodulation of $\mathrm{C} 3 \mathrm{H} / \mathrm{HeJ}$ cells by endotoxin associated protein and lipopolysaccharide endotoxin, p. 39-48. In H. Friedman and T. W. Klein (ed.) Advances in experimental medicine and biology. Microbial infections: role of biological response modifiers. Plenum Press, New York, N.Y.

509. Suzuki, H., Y. Kurihara, M. Takeya, N. Kamada, M. Kataoka, K. Jishage, O. Ueda, H. Sakaguchi, T. Higashi, T. Suzuki, Y. Takashima, Y. Kawabe, O. Cynshi, Y. Wada, M. Honda, H. Kurihara, H. Aburatani, T. Doi, A. Matsumoto, S. Azuma, T. Noda, Y. Toyoda, H. Itakura, Y. Yazaki, S. Horiuchi, K. Takahashi, J. K. Kruijt, T. Van Berkel, U. P. Steinbrecher, S. Ishibashi, N. Maeda, S. Gordon, and T. Kodama. 1997. A role for macrophage scavenger receptors in atherosclerosis and susceptibility to infection. $\mathrm{Na}$ ture 386:292-296.

510. Takada, K., N. Ohno, and T. Yadomae. 1994. Detoxification of lipopolysaccharide (LPS) by egg white lysozyme. FEMS Immunol. Med. Microbiol. 9:255-263.

511. Takada, K., N. Ohno, and T. Yadomae. 1994. Lysozyme regulates LPSinduced interleukin-6 release in mice. Circ. Shock 44:169-174.

512. Takakuwa, T., S. Endo, H. Nakae, M. Kikuchi, N. Baba, K. Inada, and M. Yoshida. 1994. Blood cytokine and complement levels in patients with sepsis. Res. Commun. Chem. Pathol. Pharmacol. 84:291-300.

513. Takeuchi, O., K. Hoshino, and S. Akira. 2000. Cutting edge: TLR2-deficient and MyD88-deficient mice are highly susceptible to Staphylococcus aureus infection. J. Immunol. 165:5392-5396.

514. Takeuchi, O., K. Hoshino, T. Kawai, H. Sanjo, H. Takada, T. Ogawa, K. Takeda, and S. Akira. 1999. Differential roles of TLR2 and TLR4 in 
recognition of gram-negative and gram-positive bacterial cell wall components. Immunity 11:443-451.

515. Takeuchi, O., A. Kaufmann, K. Grote, T. Kawai, K. Hoshino, M. Morr, P. F. Muhlradt, and S. Akira. 2000. Preferentially the $R$-stereoisomer of the mycoplasmal lipopeptide macrophage-activating lipopeptide-2 activates immune cells through a toll-like receptor 2-and MyD88-dependent signaling pathway. J. Immunol. 164:554-557.

516. Takeuchi, O., T. Kawai, P. F. Muhlradt, M. Morr, J. D. Radolf, A. Zychlinsky, K. Takeda, and S. Akira. 2001. Discrimination of bacterial lipoproteins by Toll-like receptor 6. Int. Immunol. 13:933-940.

517. Talamás-Rohana, P., S. D. Wright, M. R. Lennartz, and D. G. Russell. 1990. Lipophosphoglycan from Leishmania mexicana promastigotes binds to members of the CR3, p150,95 and LFA-1 family of leukocyte integrins. J. Immunol. 144:4817-4824

518. Tarsi-Tsuk, D., and R. Levy. 1990. Stimulation of the respiratory burst in peripheral blood monocytes by lipoteichoic acid. The involvement of calcium ions and phospholipase A2. J. Immunol. 144:2665-2670.

519. Taylor, A. H., G. Heavner, M. Nedelman, D. Sherris, E. Brunt, D. Knight, and J. Ghrayeb. 1995. Lipopolysaccharide (LPS) neutralizing peptides reveal a lipid A binding site of LPS binding protein. J. Biol. Chem. 270:1793417938.

520. Terpstra, V., E. S. Van Amersfoort, A. G. Van Veizen, J. Kuiper, and T. J. van Berkel. 2000. Hepatic and extrahepatic scavenger receptors: function in relation to disease. Arterioscler. Thromb. Vasc. Biol. 20:1860-1872.

521. Tesh, V. L., S. W. Vukajlovich, and D. C. Morrison. 1988. Endotoxin interactions with serum proteins. Relationship to biological activity, p. 4762. In J. Levin, J. W. TenCate, A. Sturk, and H. R. Buller (ed.), Bacterial endotoxins: pathophysiological effects, clinical significance, and pharmacological control. Alan R. Liss, Inc., New York, N.Y.

522. Theofan, G., A. H. Horwitz, R. E. Williams, P. S. Liu, I. Chan, C. Birr, S. F. Carroll, K. Mészáros, J. B. Parent, H. Kasler, S. Aberle, P. W. Trown, and H. Gazzano-Santoro. 1994. An amino-terminal fragment of human lipopolysaccharide-binding protein retains lipid A binding but not CD14-stimulatory activity. J. Immunol. 152:3623-3629.

523. Thomas, C. A., Y. Li, T. Kodama, H. Suzuki, S. C. Silverstein, and J. El Khoury. 2000. Protection from lethal Gram-positive infection by macrophage scavenger receptor-dependent phagocytosis. J. Exp. Med. 191:147156.

524. Tobias, P. S., J. C. Mathison, D. Mintz, J. D. Lee, V. Kravchenko, K. Kato, J. Pugin, and R. J. Ulevitch. 1992. Participation of lipopolysaccharidebinding protein in lipopolysaccharide-dependent macrophage activation. Am. J. Respir. Cell Mol. Biol. 7:239-245.

525. Tobias, P. S., K. P. McAdam, K. Soldau, and R. J. Ulevitch. 1985. Control of lipopolysaccharide-high density lipoprotein interactions by an acute phase reactant in human serum. Infect. Immun. 50:73-76.

526. Tobias, P. S., K. Soldau, and R. J. Ulevitch. 1986. Isolation of a lipopolysaccharide-binding acute phase reactant from rabbit serum. J. Exp. Med. 164:777-793.

527. Tobias, P. S., K. Soldau, and R. J. Ulevitch. 1989. Identification of a lipid A binding site in the acute phase reactant lipopolysaccharide binding protein. J. Biol. Chem. 264:10867-10871.

528. Tobias, P. S., and R. J. Ulevitch. 1993. Lipopolysaccharide binding protein and CD14 in LPS dependent macrophage activation. Immunobiology 187: 227-232.

529. Tohme, Z. N., S. Amar, and T. E. Van Dyke. 1999. Moesin functions as a lipopolysaccharide receptor on human monocytes. Infect. Immun. 67:32153220 .

530. Toth, C. A., and P. Thomas. 1992. Liver endocytosis and Kupffer cells. Hepatology 16:255-266.

531a.Treon, S. P., P. Thomas, and S. A. Broitman. 1993. Lipopolysaccharide (LPS) processing by Kupffer cells releases a modified LPS with increased hepatocyte binding and decreased TNF- $\alpha$ stimulatory capacity. Proc. Soc. Exp. Biol. Med. 202:153-158.

531. Treon, S. P., B. Anand, R. J. Ulevitch, and S. A. Broitman. 1994. CD14 mediated endogenous TNF-alpha release in HL60 AML cells: a potential model for CD14 mediated endogenous cytokine release in the treatment of AML. Leuk. Res. 18:17-21.

532. Tripp, R. J., A. Tabares, H. Wang, and S. Lanza-Jacoby. 1993. Altered hepatic production of apolipoproteins $\mathrm{B}$ and $\mathrm{E}$ in the fasted septic rat: factors in the development of hypertriglyceridemia. J. Surg. Res. 55:465472 .

533. Troelstra, A., B. N. G. Giepmans, K. P. M. Van Kessel, H. S. Lichenstein, J. Verhoef, and J. A. G. Van Strijp. 1997. Dual effects of soluble CD14 on LPS priming of neutrophils. J. Leukoc. Biol. 61:173-178.

534. Ulevitch, R. J., and A. R. Johnston. 1978. The modification of biophysical and endotoxic properties of bacterial lipopolysaccharides by serum. J. Clin Investig. 62:1313-1324.

535. Ulevitch, R. J., A. R. Johnston, and D. B. Weinstein. 1979. New function for high density lipoproteins. Their participation in intravascular reactions of bacterial lipopolysaccharides. J. Clin. Investig. 64:1516-1524.

536. Ulevitch, R. J., A. R. Johnston, and D. B. Weinstein. 1981. New function for high density lipoproteins. Isolation and characterization of a bacterial lipopolysaccharide-high density lipoprotein complex formed in rabbit plasma. J. Clin. Investig. 67:827-837.

537. Underhill, D. M., A. Ozinsky, A. M. Hajiar, A. Stevens, C. B. Wilson, M. Bassetti, and A. Aderem. 1999. The Toll-like receptor 2 is recruited to macrophage phagosomes and discriminates between pathogens. Nature 401:811-815.

538. Underhill, D. M., A. Ozinsky, K. D. Smith, and A. Aderem. 1999. Toll-like receptor-2 mediates mycobacteria-induced proinflammatory signaling in macrophages. Proc. Natl. Acad. Sci. USA 96:14459-14463.

539. Usynin, I. F., D. D. Tsyrendorzhiev, A. V. Kharkovskii, L. M. Polyakov, and L. E. Panin. 1996. Influence of plasma lipoproteins and apolipoprotein A-1 on lipopolysaccharide-induced production of reactive oxygen metabolites by rat Kupffer cells. Biochemistry (Moscow) 61:193-196.

540. Utermann, G. 1975. Isolation and partial characterization of an argininerich apolipoprotein from human plasma very-low-density lipoproteins: apolipoprotein E. Hoppe-Seylers. Z. Physiol Chem. 356:1113-1121.

541. Vabulas, R. M., P. Ahmad-Nejad, S. Ghose, C. J. Kirschning, R. D. Issels, and H. Wagner. 2002. HSP70 as endogenous stimulus of the toll/interleukin-1 receptor signal pathway. J. Biol. Chem. 277:15107-15112.

542. Van Bossuyt, H., R. B. De Zanger, and E. Wisse. 1988. Cellular and subcellular distribution of injected lipopolysaccharide in rat liver and its inactivation by bile salts. J. Hepatol. 7:325-337.

543. Van Bossuyt, H., and E. Wisse. 1988. Cultured Kupffer cells, isolated from human and rat liver biopsies, ingest endotoxin. J. Hepatol. 7:45-56.

544. van der Laan, L. J., E. A. Dopp, R. Haworth, T. Pikkarainen, M. Kangas, O. Elomaa, C. D. Dijkstra, S. Gordon, K. Tryggvason, and G. Kraal. 1999. Regulation and functional involvement of macrophage scavenger receptor MARCO in clearance of bacteria in vivo. J. Immunol. 162:939-947.

545. Van Der Laan, L. J. W., M. Kangas, E. A. Döpp, E. Broug-Holub, O. Elomaa, K. Tryggvason, and G. Kraal. 1997. Macrophage scavenger receptor MARCO; in vitro and in vivo regulation and involvement in the antibacterial host defense. Immunol. Lett. 57:203-208.

545a.Vandermeer, T. J., M. J. Menconi, J. Zhuang, H. Wang, R. Murtaugh, C. Bouza, P. Stevens, and M. P. Fink. 1995. Protective effects of a novel 32-amino acid C-terminal fragment of CAP18 in endotoxemic pigs. Surgery 117:656-662

546. Van Der Poll, T., C. C. Braxton, S. M. Coyle, M. A. Boermeester, J. C. L. Wang, P. M. Jansen, W. J. Montegut, S. E. Calvano, C. E. Hack, and S. F. Lowry. 1995. Effect of hypertriglyceridemia on endotoxin responsiveness in humans. Infect. Immun. 63:3396-3400.

547. Van Der Poll, T., and S. J. van Deventer. 1999. Cytokines and anticytokines in the pathogenesis of sepsis. Infect. Dis. Clin. North Am. 13:413-426, ix.

548. Van Deventer, S. J. H., C. J. Van Der Linden, J. J. Roord, H. Schellekens, and J. F. P. Schellekens. 1993. De introductie van immuuntherapeutica in de kliniek: de stand van zaken betreffende de anti-endotoxine-antist of HA-1A bij de bestrijding van sepsis. Ned. Tijdschr. Geneeskd. 137:334-336.

549. Van Eck, M., N. Herijgers, J. Yates, N. J. Pearce, P. M. Hoogerbrugge, P. H. Groot, and T. J. van Berkel. 1997. Bone marrow transplantation in apolipoprotein E-deficient mice. Effect of ApoE gene dosage on serum lipid concentrations, $(\beta)$ VLDL catabolism, and atherosclerosis. Arterioscler. Thromb. Vasc. Biol. 17:3117-3126.

550. Van Epps, D. E., S. J. Simpson, and R. Johnson. 1993. Relationship of C5a receptor modulation to the functional responsiveness of human polymorphonuclear leukocytes to C5a. J. Immunol. 150:246-252.

551. van Gorp, E. C., C. Suharti, H. Ten Cate, W. M. Dolmans, J. W. van der Meer, J. W. Ten Cate, and D. P. Brandjes. 1999. Infectious diseases and coagulation disorders. J. Infect. Dis. 180:176-186.

552. van Langevelde, P., J. T. van Dissel, E. Ravensbergen, B. J. Appelmelk, I. A. Schrijver, and P. H. Groeneveld. 1998. Antibiotic-induced release of lipoteichoic acid and peptidoglycan from Staphylococcus aureus: quantitative measurements and biological reactivities. Antimicrob. Agents Chemother. 42:3073-3078.

553. Van Lenten, B. J. and A. M. Fogelman. 1992. Lipopolysaccharide-induced inhibition of scavenger receptor expression in human monocyte-macrophages in mediated through tumor necrosis factor- $\alpha$. J. Immunol. 148:112116.

554. Van Lenten, B. J., A. M. Fogelman, M. E. Haberland, and P. A. Edwards. 1986. The role of lipoproteins and receptor-mediated endocytosis in the transport of bacterial lipopolysaccharide. Proc. Natl. Acad. Sci. USA 83: 2704-2708.

555. Van Oosten, M., P. C. N. Rensen, E. S. Van Amersfoort, M. Van Eck, A.-M. Van Dam, J. J. P. Brevé, T. Vogel, A. Panet, T. J. C. van Berkel, and J. Kuiper. 2001. Apolipoprotein protects against bacterial lipopolysaccharideinduced lethality: a new therapeutic approach to treat Gram-negative sepsis. J. Biol. Chem. 276:8820-8824.

556. Van Oosten, M., E. van de Bilt, H. E. De Vries, T. J. C. Van Berkel, and J. Kuiper. 1995. Vascular adhesion molecule-1 and intercellular adhesion molecule-1 expression on rat liver cells after lipopolysaccharide administration in vivo. Hepatology 22:1538-1546.

557. Van Oosten, M., E. van de Bilt, T. J. C. van Berkel, and J. Kuiper. 1998 New scavenger receptor-like receptors for the binding of lipopolysaccharide to liver endothelial and Kupffer cells. Infect. Immun. 66:5107-5112. 
558. Van Rooijen, N., and A. Sanders. 1994. Liposome mediated depletion of macrophages: mechanism of action, preparation of liposomes and applications. J. Immunol. Methods 174:83-93.

559. van Rozendaal, B. A., C. H. van de Lest, M. van Eijk, L. M. van Golde, W. F. Voorhout, H. P. van Helden, and H. P. Haagsman. 1999. Aerosolized endotoxin is immediately bound by pulmonary surfactant protein $\mathrm{D}$ in vivo. Biochim. Biophys. Acta 1454:261-269.

560. Reference deleted.

561. Venet, C., F. Zeni, A. Viallon, A. Ross, P. Pain, P. Gery, D. Page, R Vermesch, M. Bertrand, F. Rancon, and J. C. Bertrand. 2000. Endotoxaemia in patients with severe sepsis or septic shock. Intensive Care Med. 26:538-544.

562. Vesy, C. J., R. L. Kitchens, G. Wolfbauer, J. J. Albers, and R. S. Munford 2000. Lipopolysaccharide-binding protein and phospholipid transfer protein release lipopolysaccharides from gram-negative bacterial membranes. Infect. Immun. 68:2410-2417.

563. Viriyakosol, S., J. C. Mathison, P. S. Tobias, and T. N. Kirkland. 2000 Structure-function analysis of CD14 as a soluble receptor for lipopolysaccharide. J. Biol. Chem. 275:3144-3149.

564. Visintin, A., A. Mazzoni, J. H. Spitzer, D. H. Wyllie, S. K. Dower, and D. M. Segal. 2001. Regulation of toll-like receptors in human monocytes and dendritic cells. J. Immunol. 166:249-255.

565. Vogel, S. N., and M. M. Hogan. 1990. Role of cytokines in endotoxinmediated host responses, p. 238-258. In J. J. Oppenheim and E. M. Shevach (ed.), Immunophysiology. The role of cells and cytokines in immunity and inflammation. Oxford University Press, Oxford, United Kingdom.

566. Von Asmuth, E. J. U., M. A. Dentener, V. Bazil, M. G. Bouma, J. F. M. Leeuwenberg, and W. A. Buurman. 1993. Anti-CD14 antibodies reduce responses of cultured human endothelial cells to endotoxin. Immunology 80:78-83.

567. von der Mohlen, M. A., A. N. Kimmings, N. I. Wedel, M. L. Mevissen, J. Jansen, N. Friedmann, T. J. Lorenz, B. J. Nelson, M. L. White, and R. Bauer. 1995. Inhibition of endotoxin-induced cytokine release and neutrophil activation in humans by use of recombinant bactericidal/permeabilityincreasing protein. J. Infect. Dis. 172:144-151.

568. Vosbeck, K., P. Tobias, H. Mueller, R. A. Allien, K. E. Arfors, R. J. Ulevitch, and L. A. Sklar. 1990. Priming of polymorphonuclear granulocytes by lipopolysaccharides and its complexes with lipopolysaccharide binding protein and high density lipoprotein. J. Leukoc. Biol. 47:97-104.

569. Vreugdenhil, A. C. E., A. M. Snoek, C. van't Veer, J. W. Greve, and W. A. Buurman. 2001. LPS-binding protein circulates in association with apoBcontaining lipoproteins and enhances endotoxin-LDL/VLDL interaction. J. Clin. Investig. 107:225-234.

570. Wagner, J. G., and R. A. Roth. 1999. Neutrophil migration during endotoxemia. J. Leukoc. Biol. 66:10-24.

571. Wake, K., K. Decker, A. Kirn, D. L. Knook, R. S. McCuskey, L. Bouwens, and E. Wisse. 1990. Cell biology and kinetics of Kupffer cells in the liver. Int. Rev. Cytol. 118:173-229.

572. Wan, Y., P. D. Freeswick, L. S. Khemlani, P. H. Kispert, S. C. Wang, G. L. Su, and T. R. Billiar. 1995. Role of lipopolysaccharide (LPS), interleukin-1 interleukin-6, tumor necrosis factor, and dexamethasone in regulation of LPS-binding protein expression in normal hepatocytes and hepatocytes from LPS-treated rats. Infect. Immun. 63:2435-2442.

573. Wang, D., K. M. Pabst, Y. Aida, and M. J. Pabst. 1995. Lipopolysaccharideinactivating activity of neutrophils is due to lactoferrin. J. Leukoc. Biol. 57:865-874

574. Wang, J. E., P. F. Jorgensen, M. Almlof, C. Thiemermann, S. J. Foster, A. O. Aasen, and R. Solberg. 2000. Peptidoglycan and lipoteichoic acid from Staphylococcus aureus induce tumor necrosis factor alpha, interleukin 6 (IL-6), and IL-10 production in both T cells and monocytes in a human whole blood model. Infect. Immun. 68:3965-3970.

575. Wang, J. H., H. P. Redmond, Q. D. Wu, and D. Bouchier-Hayes. 1998 Nitric oxide mediates hepatocyte injury. Am. J. Physiol. 275:G1117-G1126.

576. Wasan, K. M., F. W. Strobel, S. C. Parrott, M. Lynn, W. J. Christ, L. D. Hawkins, and D. P. Rossignol. 1999. Lipoprotein distribution of a novel endotoxin antagonist, E5531, in plasma from human subjects with various lipid levels. Antimicrob. Agents Chemother. 43:2562-2564.

577. Weinrauch, Y., A. Foreman, C. Shu, K. Zarember, O. Levy, P. Elsbach, and J. Weiss. 1995. Extracellular accumulation of potently microbicidal bactericidal/permeability-increasing protein and $\mathrm{p} 15 \mathrm{~s}$ in an evolving sterile rabbit peritoneal inflammatory exudate. J. Clin. Investig. 95:1916-1924.

578. Weinreb, B. D., G. D. Shockman, E. H. Beachey, A. J. Swift, and J. A. Winkelstein. 1986. The ability to sensitize host cells for destruction by autologous complement is a general property of lipoteichoic acid. Infect. Immun. 54:494-499.

579. Weinstock, C., H. Ulirich, R. Hohe, A. Berg, M. W. Baumstark, I. Frey, H Northoff, and W. A. Flegel. 1992. Low density lipoproteins inhibit endotoxin activation of monocytes. Arterioscler. Thromb. 12:341-347.

580. Weisgraber, K. H. 1994. Apolipoprotein E: structure-function relationships. Adv. Protein Chem. 45:249-302.

581. Weisgraber, K. H., T. L. Innerarity, K. J. Harder, R. W. Mahley, R. W. Milne, Y. L. Marcel, and J. T. Sparrow. 1983. The receptor-binding domain of human apolipoprotein E. Monoclonal antibody inhibition of binding. J. Biol. Chem. 258:12348-12354.

582. Weisgraber, K. H., S. C. Rall, Jr., R. W. Mahley, R. W. Milne, Y. L. Marcel, and J. T. Sparrow. 1986. Human apolipoprotein E. Determination of the heparin binding sites of apolipoprotein E3. J. Biol. Chem. 261:2068-2076.

583. Welss, J., P. Elsbach, I. Olsson, and H. Odeberg. 1978. Purification and characterization of a potent bactericidal and membrane active protein from the granules of human polymorphonuclear leukocytes. J. Biol. Chem. 253: 2664-2672.

584. Welss, J., P. Elsbach, C. Shu, J. Castillo, L. Grinna, A. Horwitz, and G. Theofan. 1992. Human bactericidal/permeability-increasing protein and a recombinant NH2-terminal fragment cause killing of serum-resistant Gram-negative bacteria in whole blood and inhibit tumor necrosis factor release induced by the bacteria. J. Clin. Investig. 91:1122-1130.

585. Wenzel, R. P., M. R. Pinsky, R. J. Ulevitch, and L. Young. 1996. Current understanding of sepsis. Clin. Infect. Dis. 22:407-413.

586. Werb, Z. and J. R. Chin. 1983. Endotoxin suppresses expression of apoprotein $\mathrm{E}$ by mouse macrophages in vivo and in culture. A biochemical and genetic study. J. Biol. Chem. 258:10642-10648.

587. Werts, C., R. I. Tapping, J. C. Mathison, T. H. Chuang, V. Kravchenko, G. Saint, I, D. A. Haake, P. J. Godowski, F. Hayashi, A. Ozinsky, D. M. Underhill, C. J. Kirschning, H. Wagner, A. Aderem, P. S. Tobias, and R. J. Ulevitch. 2001. Leptospiral lipopolysaccharide activates cells through a TLR2-dependent mechanism. Nat. Immunol. 2:346-352.

588. Westphal, O. 1993. An old-timer's reflections on endotoxin. p. 17-36. In J. Levin, C. R. Alving, R. S. Munford, and P. L. Stotz (ed.), Bacterial endotoxin: recognition and effector mechanisms. Elsevier Science Publishers B.V., Amsterdam, The Netherlands.

589. Wheeler, A. P., and G. R. Bernard. 1999. Treating patients with severe sepsis. N. Engl. J. Med. 340:207-214

590. Worthen, G. S., N. Avdi, S. Vukajlovich, and P. S. Tobias. 1992. Neutrophil adherence induced by lipopolysaccharide in vitro: role of plasma component interaction with lipopolysaccharide. J. Clin. Investig. 91:2526-2535.

591. Wright, S. D. 1991. Multiple receptors for endotoxin. Curr. Opin. Immunol. 3:83-90.

592. Wright, S. D., P. A. Detmers, Y. Aida, R. Adamowski, D. Anderson, Z. Chad, L. G. Kabbash, and M. J. Pabst. 1990. CD18-deficient cells respond to lipopolysaccharide in vitro. J. Immunol. 144:2566-2571.

593. Wright, S. D., and M. T. C. Jong. 1986. Adhesion-promoting receptors on human macrophages recognize Escherichia coli by binding to lipopolysaccharide. J. Exp. Med. 164:1876-1888.

594. Wright, S. D., S. M. Levin, M. T. C. Jong, Z. Chad, and L. G. Kabbash. 1989. CR3 (CD11b/CD18) expresses one binding site for Arg-Gly-Aspcontaining peptides and a second site for bacterial lipopolysaccharide. J. Exp. Med. 169:175-183.

595. Wright, S. D., R. A. Ramos, A. Hermanowski-Vosatka, P. Rockwell, and P. A. Detmers. 1991. Activation of the adhesive capacity of CR3 on neutrophils by endotoxin: dependence on lipopolysaccharide binding protein and CD14. J. Exp. Med. 173:1281-1286.

596. Wright, S. D., R. A. Ramos, P. S. Tobias, R. J. Ulevitch, and J. C. Mathison. 1990. CD14, a receptor for complexes of lipopolysaccharide (LPS) and LPS binding protein. Science 249:1431-1433.

597. Wright, S. D., P. S. Tobias, R. J. Ulevitch, and R. A. Ramos. 1989. Lipopolysaccharide (LPS) binding protein opsonizes LPS-bearing particles for recognition by a novel receptor on macrophages. J. Exp. Med. 170:12311241 .

598. Wright, S. D., J. I. Weitz, A. J. Huang, S. M. Levin, S. C. Silverstein, and J. D. Loike. 1988. Complement receptor type three (CD11b/CD18) of human polymorphonuclear leukocytes recognizes fibrinogen. Proc. Natl. Acad. Sci. USA 85:7734-7738.

599. Wurfel, M. M., E. Hailman, and S. D. Wright. 1995. Soluble CD14 acts as a shuttle in the neutralization of lipopolysaccharide (LPS) by LPS-binding protein and reconstituted high density lipoprotein. J. Exp. Med. 181:17431754

600. Wurfel, M. M., S. T. Kunitake, H. Lichenstein, J. P. Kane, and S. D. Wright. 1994. Lipopolysaccharide (LPS)-binding protein is carried on lipoproteins and acts as a cofactor in the neutralization of LPS. J. Exp. Med. 180:1025-1035.

601. Wurfel, M. M., B. G. Monks, R. R. Ingalls, R. L. Dedrick, R. Delude, D. Zhou, N. Lamping, R. R. Schumann, R. Thieringer, M. J. Fenton, S. D. Wright, and D. Golenbock. 1997. Targeted deletion of the lipopolysaccharide (LPS)-binding protein gene leads to profound suppression of LPS responses ex vivo, whereas in vivo responses remain intact. J. Exp. Med. 186:2051-2056.

602. Wurfel, M. M., and S. D. Wright. 1997. Lipopolysaccharide-binding protein and soluble CD14 transfer lipopolysaccharide to phospholipid bilayers J. Immunol. 158:3925-3934.

603. Wyllle, D. H., E. Kiss-Toth, A. Visintin, S. C. Smith, S. Boussouf, D. M. Segal, G. W. Duff, and S. K. Dower. 2000. Evidence for an accessory protein function for toll-like receptor 1 in anti-bacterial responses. J. Immunol 165:7125-7132.

604. Yamamoto, K., N. Nishimura, T. Doi, T. Imanishi, T. Kodama, K. Suzuki, 
and T. Tanaka. 1997. The lysine cluster in the collagen-like domain of the scavenger receptor provides for its ligand binding and ligand specificity. FEBS Lett. 414:182-186.

605. Yanagishita, M., and V. C. Hascall. 1992. Cell surface heparan sulfate proteoglycans. J. Biol. Chem. 267:9451-9454.

606. Yang, R. B., M. R. Mark, A. Gray, A. Huang, M. H. Xie, M. Zhang, A Goddard, W. I. Wood, A. L. Gurney, and P. J. Godowski. 1998. Toll-like receptor-2 mediates lipopolysaccharide-induced cellular signalling. Nature 395:284-288.

607. Yang, R. B., M. R. Mark, A. L. Gurney, and P. J. Godowski. 1999. Signaling events induced by lipopolysaccharide-activated toll-like receptor 2. J. Immunol. 163:639-643.

608. Yao, Y. M., H. Redl, S. Bahrami, and G. Schlag. 1998. The inflammatory basis of trauma/shock-associated multiple organ failure. Inflamm. Res 47: 201-210.

609. Ying, S. C., H. Jiang, Y. B. Kim, and H. Gewurz. 1993. C1q peptides bind endotoxin and inhibit endotoxin-initiated activation of the classical complement pathway. J. Immunol. 150:304A.

610. Yong, K. L., and D. C. Linch. 1993. Granulocyte-macrophage-colony-stimulating factor differentially regulates neutrophil migration across IL-1-activated and nonactivated human endothelium. J. Immunol. 150:2449-2456.

611. Yoshimura, A., E. Lien, R. R. Ingalls, E. Tuomanen, R. Dziarski, and D. Golenbock. 1999. Cutting edge: recognition of Gram-positive bacterial cell wall components by the innate immune system occurs via Toll-like receptor 2. J. Immunol. 163:1-5.

612. Yu, B., E. Hailman, and S. D. Wright. 1997. Lipopolysaccharide binding protein and soluble CD14 catalyze exchange of phospholipids. J. Clin. Investig. 99:315-324.
613. Yu, W., E. Soprana, G. Cosentino, M. Volta, H. S. Lichenstein, G. Viale, and D. Vercelli. 1998. Soluble CD14(1-152) confers responsiveness to both lipoarabinomannan and lipopolysaccharide in a novel HL-60 cell bioassay. J. Immunol. 161:4244-4251.

614. Zhang, F. X., C. J. Kirschning, R. Mancinelli, X. P. Xu, Y. Jin, E. Faure, A. Mantovani, M. Rothe, M. Muzio, and M. Arditi. 1999. Bacterial lipopolysaccharide activates nuclear factor- $\mathrm{k}$ through interleukin-1 signaling mediators in cultured human dermal endothelial cells and mononuclear phagocytes. J. Biol. Chem. 274:7611-7614.

615. Zhang, G. H., D. M. Mann, and C. M. Tsal. 1999. Neutralization of endotoxin in vitro and in vivo by a human lactoferrin-derived peptide. Infect. Immun. 67:1353-1358.

616. Ziegler-Heitbrock, H. W. L., H. Pechumer, I. Petersmann, J. J. Durieux, N. Vita, M. O. Labeta, and M. Ströbel. 1994. CD14 is expressed and functional in human B cells. Eur. J. Immunol. 24:1937-1940.

617. Ziegler-Heitbrock, H. W. L., and R. J. Ulevitch. 1993. CD14: cell surface receptor and differentiation marker. Immunol. Today 14:121-125.

618. Ziegler, E. J., J. A. McCutchan, J. Fierer, M. P. Glauser, J. C. Sadoff, H. Douglas, and A. I. Braude. 1982. Treatment of Gram-negative bacteremia and shock with human antiserum to a mutant Escherichia coli. N. Engl. J. Med. 307:1225-1230.

619. Zimmerli, S., S. Edwards, and J. D. Ernst. 1996. Selective receptor blockade during phagocytosis does not alter the survival and growth of $\mathrm{Myco}$ bacterium tuberculosis in human macrophages. Am.J.Respir.Cell Mol. Biol. 15:760-770.

620. Zuckerman, S. H, and L. O'Neal 1994. Endotoxin and GM-CSF-mediated down-regulation of macrophage apo E secretion is inhibited by a TNFspecific monoclonal antibody. J. Leukoc. Biol. 55:743-748. 